Portland State University

PDXScholar

Spring 6-12-2018

\title{
Little Russia: Patterns in Migration, Settlement, and the Articulation of Ethnic Identity Among Portland's Volga Germans
}

Heather Ann Viets

Portland State University

Follow this and additional works at: https://pdxscholar.library.pdx.edu/open_access_etds

Part of the History Commons

Let us know how access to this document benefits you.

Recommended Citation

Viets, Heather Ann, "Little Russia: Patterns in Migration, Settlement, and the Articulation of Ethnic Identity Among Portland's Volga Germans" (2018). Dissertations and Theses. Paper 4440.

https://doi.org/10.15760/etd.6324

This Thesis is brought to you for free and open access. It has been accepted for inclusion in Dissertations and Theses by an authorized administrator of PDXScholar. Please contact us if we can make this document more accessible: pdxscholar@pdx.edu. 


\title{
Little Russia:
}

Patterns in Migration, Settlement, and the Articulation of Ethnic Identity Among Portland's Volga Germans

by

Heather Ann Viets

A thesis submitted in partial fulfillment of the requirements for the degree of

\author{
Master of Arts \\ in \\ History
}

Thesis Committee:

Katrine Barber, Chair

Marc Rodriguez

Tim Garrison

\section{Portland State University}


(C) 2018 Heather Ann Viets 


\begin{abstract}
The Volga Germans assert a particular ethnic identity to articulate their complex history as a multinational community even in the absence of traditional practices in language, religious piety, and communal lifestyle. Across multiple migrations and settlements from the eighteenth to the twentieth centuries, the Volga Germans' selfconstructed group identity served historically as a tool with which to navigate uncertain politics of belonging. As subjects of imperial Russia's eighteenth-century colonization project the Volga Germans held a privileged legal status in accordance with their settlement in the Volga River region, but their subsequent loss of privileges under the reorganization and Russification of the modern Russian state in the nineteenth century compelled members of the group to immigrate to the Midwest in the United States where their distinct identity took its full form. The Volga Germans' arrival on the Great Plains coincided with an era of mass global migration from 1846 to 1940 , yet the conventional categories of immigrant identity that subsumed Volga Germans in archival records did not impede their drive for community preservation under a new unifying GermanRussian identity. A contingent of Midwest Volga Germans migrated in 1881 to Albina, a railroad town across the Willamette River from Portland, Oregon where the pressures of assimilation ultimately disintegrated traditional ways of life-yet the community impulse to articulate its identity remained. Thus, while Germans are the single largest ethnic group in the U.S. today numbering forty-two million individuals, Portland's Volga German community nevertheless continues to distinguish itself ethnically through its nostalgia for a unique past.
\end{abstract}




\section{Acknowledgments}

I want to extend my sincerest gratitude to Steve Schreiber, a local Volga German descendant whose support and knowledge guided this project. Steve served as the Oregon Chapter President of the American Historical Society of Germans from Russia (AHSGR), the Interim Director of the Center for Volga German Studies (CVGS), and he created the websites The Volga Germans in Portland and Norka, Russia. Steve pioneered the study of the Portland Volga German community through the collection and documentation of immense heritage materials. His passion is recognizable to all who come upon the Portland community of Volga Germans.

Thank you to Marilyn Schleining Schultz, Harold and Loretta Kammerzell, and Roy Derring, who donated their time to participate in oral history interviews for this project. 


\section{Table of Contents}

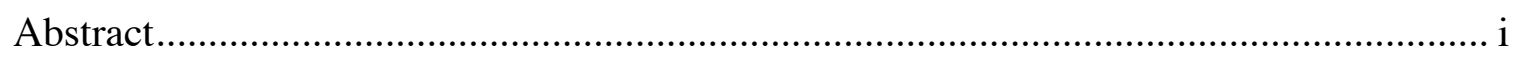

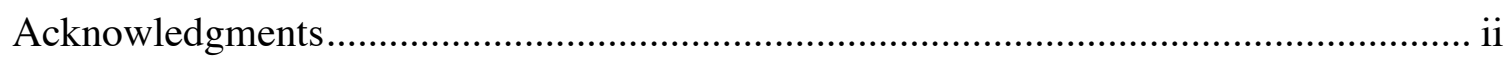

Introduction

Uncertain Spaces: Migration, Settlement, and the Politics of Belonging ........................ 1

\section{Chapter I}

Down Along the Mother Volga: Imperial Russia’s Colonization Project...................... 10

Chapter II

To Make Distant Fields Fertile: Immigration to the U.S. Midwest............................... 28

Chapter III

Every Beginning Has an End: Assimilation in Albina............................................. 47

Chapter IV

We Are Also Bound Together: Nostalgia for a Shared Past......................................... 65

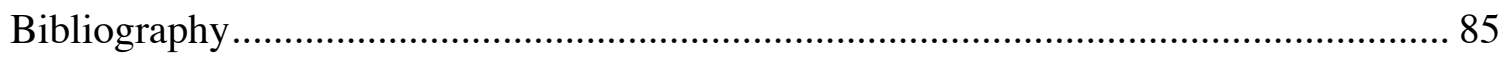

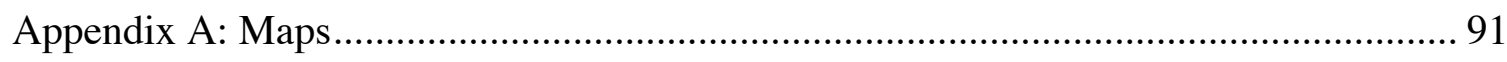

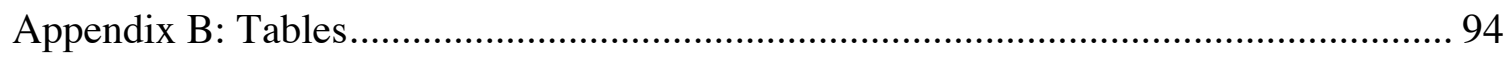

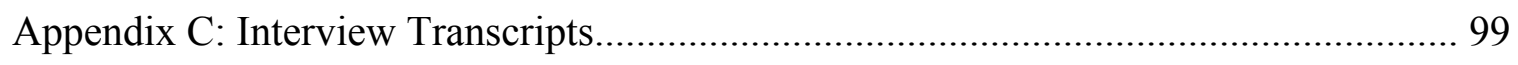




\section{Introduction \\ Uncertain Spaces: \\ Migration, Settlement, and the Politics of Belonging}

A fragile note written on thin paper in a meticulous script makes an exuberant announcement: the St. Nicholas Russian Orthodox Church at 763 Mallory Avenue is consecrated - "the greatest event for the local Russian colony!" The 1928 note positions the opening of the church squarely within the center of bustling Russian life in Portland. Yet behind the simple wooden structure lies a story that predates its consecration as a Russian Orthodox institution. The original structure, so long forgotten that it does not seem to possess a definitive name, is referenced in various documents as the German Evangelical Congregation Church, the Free Evangelical Brethren Church, and a host of other titles. The lack of a singular title for the church highlights the complex heritage that belies the simple structure. This church, erected in 1900, represented the center of community life for the Volga Germans, immigrants of German and Russian heritage who crafted a unique ethnic identity across multiple migrations and settlements. Although the Volga Germans disappeared from historical accounts of Portland, their presence persists in public memory. ${ }^{1}$

This thesis seeks to examine the historical development of self-constructed Volga German ethnic identity and the persistence of that identity among members of the Portland community today. Using a range of materials including archival records, newspapers, census lists, and oral histories, this thesis argues that the privileged legal

\footnotetext{
${ }^{1}$ Ethnology Collection, Mss 1521. Oregon Historical Society Research Library. Portland, OR.
} 
status once held by the Volga Germans in the Russian Empire laid the foundation for an autonomous group identity sustained through a pattern of migration and settlement where the hazy edges of "insider" and "outsider" and the politics of formal and informal membership remained at odds with the boundaries of polities. Their construction of a unique ethnic identity articulated through nostalgia allows the Volga Germans to imagine themselves as simultaneously assimilated and diasporic, within and without national boundaries. $^{2}$

Traditional Volga German narrative reveals important clues about the group's impulse for an autonomous ethnic and cultural status. The familiar Volga German story begins with German peasants who sought refuge from the war-torn Holy Roman Empire and immigrated to the Russian Empire in 1764 on the benevolent promises of the Empress Catherine the Great, a German princess who married into the Russian crown. The peasants settled in autonomous colonies organized according to their religious denominations on the remote Russian steppe surrounding the Volga River where they slipped into an isolated way of life centered on religious piety, devotion to the land, and communal living. Over the next hundred years the colonists renounced their German homeland, yet they also maintained social, religious, and economic separation from the Russians. Their immigration to the Midwest in the United States and finally to Albina in Oregon represented the natural progression of their religious, cultural, and political values. While this narrative tends to overlook the complexities of imperialism and settler

\footnotetext{
${ }^{2}$ Amber N. Nickell, “Cultivating 'Roots': Towards a Diasporically Imagined Transnational Community, the American Historical Society of Germans from Russia, 1968-1978," Traversea: Journal of Transatlantic History 2 (2012), 7-8.
} 
colonialism, it nevertheless demonstrates the stories through which the Volga Germans came to know themselves.

The Volga Germans' self-defined identity was a tool with which to navigate the uncertain spaces they occupied. They formed closed corporate communities bound by the particularism of their cultural, religious, and linguistic practices. As the historian Kurt E. Kinbacher explains, Volga German communities comprised "speech islands" where "divergent, archaic German dialects and a handful of Russian nouns" allowed the Germans to recognize one another's villages of origin through subtle variations in accent and word usage. These closed communities fostered a sense of village loyalty underscored by the relative lack of infrastructure for travel and communication in the remote Russian provinces. ${ }^{3}$

The Volga Germans remained in the Russian Empire for a century until the revocation of key elements of their protected legal status along with the newfound pressures of Russification drove them to immigrate to the U.S. Midwest during an era of mass global migration. The Volga Germans who settled in the Midwest continued to assert their ethnic identity as an expression of solidarity for community members dispersed across polities. Their subsequent arrival on the banks of the Willamette River in Oregon in 1881 represented the final migration for many Volga Germans, but it also marked the beginning of a complex story about identity, nostalgia, and the ways in which we conceptualize the past.

\footnotetext{
${ }^{3}$ Kurt E. Kinbacher, "Life in the Russian Bottoms: Community Building and Identity Transformation among Germans from Russia in Lincoln, Nebraska, 1876 to 1926," Journal of American Ethnic History 26, no. 2 (Winter 2007), 32-33.
} 
The story of the Volga Germans' settlement in Albina—now a neighborhood of Northeast Portland —offers an opportunity to examine the wider history of migration and settlement in the U.S. West. This thesis is informed by modern historical frameworks that place Volga German immigration within the context of inter-connected imperialist and settler colonial structures. These modern frameworks reject prior assertions by the historian Frederick Jackson Turner, whose environmental-regional concept of the frontier dominated study of the U.S. West until the emergence of the New Western History movement in the 1980s.

In his influential essay of 1893 entitled "The Significance of the Frontier in American History," Turner espoused a notion of American exceptionalism marked by the special adaptability of the people along a line of western progression toward civilization as the settlers met and surpassed each frontier boundary. According to Turner's environmental theory, continual westward expansion shaped uniquely American characteristics of independence and adaptability. While he acknowledged the presence of indigenous peoples and ancient trading routes in the frontier prior to settler exploration, Turner treated indigenous peoples as stepping-stones in the path toward higher civilization. To support this assertion he cited the "law of continuity and development," whereby settlers who conquered the frontier helped to develop and elevate civilization. Turner's doctrine demonstrates the mythic, triumphalist, and white supremacist narratives central to Euro-American imperialism and settler colonialism. ${ }^{4}$

\footnotetext{
${ }^{4}$ Frederick Jackson Turner, "The Significance of the Frontier in American History," The Frontier in American History (New York: Henry Holt \& Company, 1920), 2-3.
} 
To study western history according to regional confines, without engaging the larger intellectual frameworks of imperialism and settler colonialism, is to risk falling prey to the myth of American exceptionalism promoted by Turner. The historian Jack P. Greene argues that neglecting to employ imperial frameworks in the study of U.S. history "parochializes and trivializes" both colonial and national histories. As Greene contends, "the time is right for colonialists to become more imperial" in order to reshape scholarly understanding of U.S. history. ${ }^{5}$

To paraphrase the historian Michael Adas, imperialism is a project involving the following elements: the fundamental reconceptualization of spatial and temporal understandings; systematic rationalization of states' and societies' organizational structures; rigid delineation of boundaries both in regard to physical frontiers and internal administrative divisions; mapping and measuring of imperial territories; discovery of natural resources as a task of state administration; and the use of censuses and surveys to collect information and to control subject populations. Advances in technology also provide modern imperial states with the tools to apply force. Migration is a device with which imperial powers secure rule in areas with relatively sparse populations by establishing settler colonies. ${ }^{6}$

Settler colonialism therefore occurs within the larger framework of imperial expansion. As paraphrased from Greene, settler colonialism is defined by its own set of criteria: the permanence of the settling population and the balance of genders therein;

\footnotetext{
${ }^{5}$ Jack P. Greene, "Colonial History and National History: Reflections on a Continuing Problem," William and Mary Quarterly 64, no. 2 (Third Series, April 2007), 235.

${ }^{6}$ Michael Adas, "Imperialism and Colonialism in Comparative Perspective," International History Review 20, no. 2 (June 1998), 376, 381.
} 
transplantation of cultural, social, and political institutions; continual political dominance of settlers' descendants over indigenous peoples; exertion of wide control over the formation of economic, social, and political structures; creation of polities that become both centers for nation-building and manufacturers of historical constructs that justify the settlers' activity; absorption of these constructs into political and legal-juridical institutions; and the advancement of origin myths and national metaphors. ${ }^{7}$

A great deal of historical evidence describes a complex West in which racially diverse actors participated in an economic reality that relied heavily on eastern institutions, the federal government, and inter-imperial networks-yet the notion of American exceptionalism at the core of Turner's theory remains pervasive in popular understanding of the U.S. West. ${ }^{8}$ As the historian Paul A. Kramer argues, faulty analytical frameworks impede scholarly understanding of the West and of U.S. history as a whole through the "bounding of historical questions and answers by the territorial borders of nation-states." Kramer cites the "denial of the relevance of the imperial to U.S. history" as a persistent feature of scholarship that detaches U.S. history from other "comparable pasts" and therefore limits historical understanding. ${ }^{9}$

Migration is a key component of imperial and settler colonial history wherein the interaction between local, national, and international forces comprise a "large-scale, nonnational space of historical investigation" through which to investigate "long-distance connection and interaction" of regions, as Kramer explains. The era of mass global

${ }^{7}$ Greene, "Colonial History and National History," 237.

${ }^{8}$ Earl Pomeroy, "Toward a Reorientation of Western History: Continuity and Environment," Mississippi Valley Historical Review 41, no. 4 (March 1955), 581.

${ }^{9}$ Paul A. Kramer, "Power and Connection: Imperial Histories of the United States in the World," American Historical Review 116, no. 5 (December 2011), 1357. 
migration from 1846 to 1940 demonstrates the extent to which national histories are interconnected through global forces. ${ }^{10}$ Despite the emphasis placed on transatlantic migration from Europe to the U.S., the scholar Adam McKeown points out that migrations across the world remained "broadly comparable in size and timing" during this era as industrial development around the world operated "beyond the direct influence" of the West. The forces that drive migration extend beyond economics and international relationships to include family structures, gender, social networks, and other cultural elements specific to each migrant group. As McKeown argues, migration cannot be reduced to relocation as each migrant network "occupies a distinct niche that articulates with many local histories but has its own specific patterns."

The nation-state is an important conceptual category to clarify for the study of migration and settlement within the inter-imperialist context. As the scholar Rogers Brubaker explains, prior to $1500 \mathrm{CE}$ in Europe the organization of polities ranged from micro-principalities to city-states and loose tribal confederations. After approximately $1500 \mathrm{CE}$, military conquests aided in the bureaucratic centralization of territorial states and laid the foundation for the rise of nation-states. The idealized conception of the nation-state involves the mapping of borders, culture, and citizenry in such a manner that the territorial organization of the state matches the "imagined community" of the nation. Distinctive cultural homogeneity is present and stops at the borders of the nation-state; all permanent residents of the nation-state are citizens; and legal citizenship is consistent with "cultural nationality." Yet the politics of membership and belonging are problematic

\footnotetext{
${ }^{10}$ Ibid, 1351 .

${ }^{11}$ Adam McKeown, "Global Migration, 1846-1940," Journal of World History 15, no. 2 (June 2004), 155-157, 180-181.
} 
within this concept of the nation-state, as Brubaker argues. ${ }^{12}$ This thesis illustrates the ways in which historical complexities breach the limits of familiar categories of identity for groups like the Volga Germans, whose relationship to formal and informal belonging played a significant role in the group's migration patterns and community identity in multiple polities.

Citizenship and belonging are distinguishable from each other in important ways, but such distinctions may not be reflected in the organization of a nation-state. A group can possess citizenship — or formal belonging in a nation-state — despite a lack of substantive belonging due to an inability to access the rights of that citizenship, among other impediments to acceptance as full members of the national society. Variations between "everyday membership practices" and "codified" membership are further complicated by migration wherein new dynamics in membership politics are generated "insofar as the re-settlers are not fully integrated or accepted" or where they are "accorded certain privileges or benefits that become contested." ${ }^{13}$ We see this with the Volga Germans when their privileged colonial status in the Russian Empire, though formally codified in the imperial declaration of the Second Manifesto, ultimately highlighted them as subjects for conversion in accordance with the tenets of Russification.

While each migrant group develops according to unique social processes, the Volga Germans demonstrate a strong impulse to define themselves as ethnically distinct

\footnotetext{
${ }^{12}$ Rogers Brubaker, "Migration, Membership, and the Modern Nation-State: Internal and External Dimensions of the Politics of Belonging," Journal of Interdisciplinary History 41, no. 1 (Summer 2010), 61-63.

${ }^{13}$ Ibid, 64-67.
} 
from other migrants who settled in the U.S. during the era of mass global migration. The privileges they temporarily enjoyed as colonists in Russia and their lack of affiliation with any particular home nation made them difficult to categorize even as many of their traditional practices in religion, agriculture, and communal life faded away. Archival records classify Volga Germans as either Germans or Russians, yet the Volga Germans themselves reject both identities. This paradox demonstrates that although we often rely on familiar categories such as ethnicity and nationality to organize the world around us, these conceptual frameworks impede complex understanding of multinational groups such as the Volga Germans whose history defies organizational norms. This thesis offers a transnational study of Volga German migration history within the context of interimperialist networks to address gaps in conventional categories of identity that neglect multinational community histories. 


\section{Chapter I}

\section{Down Along the Mother Volga: Imperial Russia's Colonization Project}

This chapter discusses the array of diplomatic efforts that comprised the Russian Empire's colonization project and the ways in which traditional Volga German historiography often omits the historical reality of extensive government involvement in stories about the settlement of the colonies. Empress Catherine II's Second Manifesto, a decree that offered substantial protections for immigrants who wished to settle in the Russian Empire, represented the most progressive policy of its time anywhere in Europe, but the success of the Second Manifesto emerged only after years of reconfigurations by prior imperial rulers. Despite the promises put forth with confidence in the Second Manifesto, many details of the colonization campaign remained in flux during the course of the imperial project as unanticipated complications arose. ${ }^{14}$

The complex circumstances of the colonization campaign are largely unrecognized in Volga German historiography, which typically offers a continuous narrative in which peasants of eighteenth-century Germany fled persecution and reemerged as colonists in Russia under the benevolence of Empress Catherine. Community memory features tales of hardship, self-sufficiency, and lonely accomplishment - themes similar to those of Turner's nineteenth-century frontier - that blend with elements of Russian folklore to compose a distinctive Volga German chronicle of identity.

\footnotetext{
${ }^{14}$ Igor R. Pleve, The German Colonies on the Volga: The Second Half of the Eighteenth Century, trans. Richard R. Rye (Lincoln, Neb.: American Historical Society of Germans from Russia, 2001), 68.
} 
A brief review of Volga German historiography establishes a narrative basis against which to compare the facts unearthed by modern scholars. The earliest examples of this historiography are found in the incomplete subjective accounts of visitors to the colonies in the late 1700s such as the pastor Johann Gottlieb Georgi and the scholar P.S. Pallas. For instance, Georgi describes traditional German timber-framed homes in the colony of Katharinenstadt, but the Russian government documented the construction of $\log$ homes for the colonists there. Romanticized early reports nevertheless contain important information like census data that remains useful for scholars today. ${ }^{15}$

Scholars of German-Russian descent, including Gottlieb Beratz and Jacob Dietz, carried out the first attempts at rigorous analysis of Volga German history in the colonies through the creation of organizational time periods and the introduction of historical documents in the eighteenth and early nineteenth centuries. Despite the achievements of these early Volga German scholars - especially Dietz, a lawyer who interpreted Russian government documents - their writings nonetheless reveal tendencies toward imagination and dramatization. ${ }^{16}$

It was not until the rise of heritage study in the 1970s that the U.S. scholars James W. Long, Fred C. Koch, and co-authors Richard D. Scheuerman and Clifford E. Trafzer published scholarly analyses of Volga German history, although valuable materials held in U.S.S.R. archives remained inaccessible at that time. ${ }^{17}$ Perhaps the most rigorous

\footnotetext{
${ }^{15}$ Ibid, 16-17.

${ }^{16}$ Ibid, 23.

${ }^{17}$ Ibid, 15-30. See James W. Long, From Privileged to Dispossessed: The Volga Germans, 1860-1917 (Lincoln: University of Nebraska Press, 1988); Fred C. Koch, The Volga Germans: In Russia and the Americas, from 1763 to the Present (University Park:
} 
analysis of early Volga German history to date is found in the work of Igor R. Pleve, a scholar from Russia who challenges many Volga German origin myths from traditional histories in his 2001 book, The German Colonies on the Volga: The Second Half of the Eighteenth Century. Pleve utilizes documents from the Russian state archives to establish an historically accurate context for his argument that certain violations of the Volga Germans' rights in the Second Manifesto proved necessary for the success of the colonization project. He concludes that the Volga Germans emerged as their own national group at the end of the eighteenth century and asserts that the "full dramatism" of their early history "established the basis for their future prosperity." ${ }^{18}$ Though much archival material still awaits translation and scholarly study - particularly in light of new analytical frameworks around imperialism and colonialism-Pleve successfully establishes a new groundwork from which scholars can re-contextualize the historical development of Volga German identity.

Contemporary popular discourse on migration and multiculturalism in Germany often neglects to acknowledge the complex historical reality of Central Europe where populations moved continually across changing and fracturing borders. Prior to the rise of European nation states, religious ideology remained synonymous with political orientation, while alliances and rivalries existed between principalities both sovereign

Pennsylvania State University Press, 1977); Richard D. Scheuerman and Clifford E. Trafzer, The Volga Germans: Pioneers of the Northwest (Moscow: University Press of Idaho, 1980).

${ }^{18}$ Pleve, The German Colonies on the Volga, 34, 309. 
and subordinate to imperial power. ${ }^{19}$ When the imperial Russian government offered Europeans the opportunity to obtain protected legal status in its colonization project, many inhabitants of the Holy Roman Empire took up the offer to immigrate.

The Holy Roman Empire, located in western and central Europe from 962 to 1806 CE, contained many independent kingdoms, duchies, and religious principalities. The largest and most powerful territory of the empire was a collection of separate polities that we refer to as the kingdom of Germany. The German kingdom fractured under economic turmoil and administrative chaos with Martin Luther's Reformation of 1521 and the cascade of subsequent warfare between Central European powers, including the Thirty Years War and the Seven Years War. Heavy war taxes and widespread poverty exacerbated discord between the peasantry and the princes over deteriorating social conditions. ${ }^{20}$ Heightened political and social tensions raised fear among members of pietistic minority Protestant sects that broke off from the mainstream Protestant and Catholic powers. Members of these groups believed in the absolute authority of scripture and lived according to internal principles that offered community identity and a value system not accessible in the external world. They found that warfare violated Christian

\footnotetext{
${ }^{19}$ Klaus J. Bade, "From Emigration to Immigration: The German Experience in the Nineteenth and Twentieth Centuries," Central European History 28, 4 (1995), 507. ${ }^{20}$ Hattie Plum Williams, The Czar's Germans: With Particular Reference to the Volga Germans, ed. Emma S. Haynes, Phillip B. Legler, and Gerda S. Walker (Lincoln, Neb.: American Historical Society of Germans from Russia, 1975), 1-2; Mary Koellermeier Weikum, "Oregon Germans That Came From Russia," The Bulletin, March 9, 1977, 7.
} 
commandments, so they objected to military service - a tradition still upheld by groups like the Mennonites today. ${ }^{21}$

Just as the Holy Roman Empire radicalized and fragmented, the Russian Empire strengthened and expanded. The Emperor Peter I, also known as Peter the Great, sought to reign in conflict around imperial borders and solidify his absolute power with reforms for westernization. Emperor Peter reorganized Russia around local and centralized governing structures, promoted the translation of western texts, established a large army of conscripted peasants, built weapons with serf labor, and introduced a fleet of warships. Bolstered by a newly enhanced imperial infrastructure, the emperor charged into the Northern War in 1700. He aimed to defeat Sweden, which owned the Gulf of Finland, and hoped to gain control of the Baltic Sea region. Emperor Peter secured the area surrounding the mouth of the Neva River in approximately 1712 and established a new imperial capital, Saint Petersburg. His efforts for reform, westernization, and expansion paved the way for the rule of his successors who attempted to secure the borders of the empire with a variety of colonization measures..$^{22}$

Russian bureaucrats who continued Emperor Peter's modernization project grew concerned that feudalism constituted an obstacle to the economic development of the borderlands they wished to secure. Feudalism presented problems for the empire insofar as serfdom prohibited the free movement of peasants, and landowners feared that the establishment of new farms in unfamiliar territory carried severe risks. Nevertheless, the

${ }^{21}$ The New Conscientious Objection: From Sacred to Secular Resistance, ed. Charles C. Moskos and John Whiteclay Chambers (New York: Oxford University Press, 1993), 9. ${ }^{22}$ Lindsey Hughes, Russia in the Age of Peter the Great (New Haven: Yale University Press, 1998), 210. 
authorities wished to maintain the validity of the feudal system upon which much of the empire operated. They opened the land around the Volga River-the chief waterway of the empire extending from north of Moscow to the Caspian Sea-for free settlement in $1731 .^{23}$ Although the authorities allotted funds and grain for settlers, attempts to establish control in the borderlands failed after an attack on Russian soldiers stationed in the area. Subsequent attempts to populate the region remained unsuccessful until the government revised its settlement strategy to incorporate foreign colonists and introduce new trades to the empire. However, the government's first attempts to establish colonial populations of Georgians, Armenians, French Protestants, and Prussians failed. Russian authorities then attempted to purchase Central Asian Kalmyk captives from other tribes - they hoped to convert the indigenous prisoners to Christianity and teach them to farm - but they terminated the unsuccessful plan in 1765 .

The Empress Catherine II, also known as Catherine the Great and the wife of Peter III, took the throne in 1762 and continued to revise the colonization strategy. She issued her First Manifesto on December 4, 1762 to allow all immigrants except Jews to settle in the empire. The decree also stipulated that the government welcomed back without penalty subjects who previously fled the empire. Although Russian diplomats across Europe circulated hundreds of copies of the First Manifesto in several languages, efforts to recruit immigrants remained unsuccessful as the government failed to provide specific plans for an infrastructure to support a large colonial population. ${ }^{24}$

\footnotetext{
${ }^{23}$ For a map of the Volga River region of Russia, see Figure 1 in Appendix A, p. 91.

${ }^{24}$ Pleve, The German Colonies on the Volga, 55-62.
} 
Empress Catherine consulted with government officials to amend the First Manifesto, and on July 22, 1763 she announced the Second Manifesto. The revised decree clarified the aims of the government colonization program to develop and populate lands:

We acknowledge that not a small number of such regions still lie fallow, that could be advantageously and easily most usefully utilized to be populated and lived in. Most of these lands have hidden within their bowels an inexhaustible wealth of all kinds of valuable ores and metals; and because the same are richly provided with woodlands, rivers, lakes and seas situated for commerce, so they are also uncommonly wellsituated for the furtherance and increase of many kinds of manufacturers, factories and for various other establishments.

The government encouraged immigrants to settle in the borderlands it wished to secure and invited settlers to bring new trades to modernize the empire:

We shall allow all foreigners to come into Our Empire, in order to take up residence in all provinces wherever it is agreeable to each of them... whether they have the desire to settle on free and fertile land in entire colonies and lands to farm or to take up all kinds of useful pursuits. ${ }^{25}$

The Second Manifesto also declared special rights for colonists and their descendants to enjoy a privileged status apart from other subjects of the empire. Privileges offered to the colonists included the rights to retain their own language and practice their own religion; permanent freedom from military service; exemption from all taxes for thirty years for colonists who settled on the free lands indicated in the decree and exemption from import fees on goods for colonists who remained in the empire a minimum of ten years; sponsorship of interest-free loans from the government for ten years; access to lands

25 "Manifesto of Catherine, the Great," Germans from Russia Heritage Collection, last modified January 26, 2018, https://library.ndsu.edu/grhc/history_culture/history/people2.html. 
guaranteed suitable for farming; and the right to local self-governance in the colonies. Additionally, the government promised to pay for immigrants' travel expenses and to organize their settlement in the colonies. The government also imposed certain restrictions on the colonists including the order not to impinge on the authority of the Russian Orthodox Church and the requirement that colonists who wished to leave the empire one to five years after settlement must reimburse the government for half their living expenses. ${ }^{26}$

Imperial officials established a new agency, the Chancery of Oversight of Foreigners, in Saint Petersburg to manage recruitment and settlement for the colonization program. The Chancery held several responsibilities including the duty to promote a positive image of the Russian Empire, to ensure that provincial governors assisted traveling colonists during their journeys, and to encourage immigrants to settle in borderlands such as the Volga region. Representatives from the Chancery initiated the colonization process by consulting Russian diplomats across Europe to organize publication of the Second Manifesto in local newspapers. The peoples of England and Holland, where economic development already surpassed that of the Russian Empire, showed little interest in the Second Manifesto. Authorities in Sweden, Austria, Spain, France, and some German states of the Holy Roman Empire feared mass immigration of their populaces and resisted diplomats' efforts to circulate materials. The Russian diplomat at Hamburg, a free city in the northern German kingdom, noted that print materials remained inaccessible to large numbers of the illiterate peasant population in

\footnotetext{
${ }^{26}$ Pleve, The German Colonies on the Volga, 63-68.
} 
rural areas. He suggested a dispatch of recruiters to deliver the news orally in rural provinces. The recruiters enjoyed a level of success that surpassed diplomats' efforts, and in 1765 the Russian ambassador from Regensburg in the German kingdom asked the Chancery to organize an infrastructure for recruiters to direct prospective immigrants to the port of Lübeck on the Baltic coast. ${ }^{27}$

By 1766 feudal lords from several states took action to forbid immigration to Russia as the German kingdom lost much of its tax base and labor force due to the success of the recruitment campaign. ${ }^{28}$ Peasants from the rural central and southern regions of the German kingdom responded enthusiastically to recruitment efforts, but lords alleged that recruiters illegally and secretly transported the peasants to collection points in violation of a law that required the diplomats to obtain permission from the lords. Tension grew as Russian diplomats and recruiters faced new pressure to cease their efforts in the German kingdom. Some states expelled Russian ambassadors and printed false stories about the inhumane treatment of immigrants who arrived in the Russian Empire. On May 15, 1766, without permission from Empress Catherine, the Russian ambassador at Regensburg who originally asked the Chancery to organize dispatch out of Lübeck ordered recruiters to cease their activities. By the time recruitment ended in

\footnotetext{
${ }^{27}$ Ibid, 67-76. Pleve notes that some Chancery documents from the early colonization period still await further study in the Russian State Historical Archive (RGIA), Russian Archive of Ancient Acts (RGADA), and the State Archive of Saratov Oblast. Of particular interest are materials from the Journal of the General Session of the Office [Kontora] of Oversight of Foreigners and the Journal of the Office of Oversight of Foreigners in Saratov.

${ }^{28}$ Williams, The Czar's Germans, 85.
} 
Europe in 1766 more than thirty thousand new immigrants had arrived in Russia and three thousand families had already settled in the Volga region. ${ }^{29}$

Recruiters first attempted to dispatch colonists to the Russian Empire by land, but the path eastward through Bohemia, Prussia, and Poland called into question diplomatic relations with those kingdoms. The government also determined that travel by land incurred excessive expenses and they organized an alternative sea route. The first group of colonists to arrive in the Russian Empire boarded ships at the port of Danzig in the kingdom of Poland and sailed across the Baltic Sea to Saint Petersburg in 1763, but authorities in Poland and surrounding Prussia disapproved of Russia's colonization program and halted emigration from Danzig. Lübeck, a powerful merchant city in a trading guild called the Hanseatic League, emerged as the ideal point of dispatch due to its geographic location on the coast of the Baltic Sea and its strong trade relations with Saint Petersburg. The masses of recruited colonists who gathered in Lübeck for departure exceeded diplomats' expectations and by 1766 the city could not provide enough ships to accommodate the number of passengers. The Chancery enlisted the help of two English ships to expedite the delivery of colonists to Russia before winter of that year, and the international effort resulted in the successful transportation of nearly twenty-two thousand people from Lübeck to Russia in 1966. Ivan Kuhlberg, a bureaucrat in the Russian government, compiled ship lists that provide valuable information about the 1766 immigration wave. The lists feature the names and occupations of twenty thousand

\footnotetext{
${ }^{29}$ Pleve, The German Colonies on the Volga, 78-81.
} 
immigrants who arrived that year in Oranienbaum, Russia. Many Volga German descendants today trace their ancestry to individuals documented in the Kuhlburg lists. ${ }^{30}$

The journey from Lübeck through the Baltic Sea and the Gulf of Finland to the Russian Empire spanned approximately nine hundred miles and took up to three months. ${ }^{31}$ Immigrants initially disembarked for customs procedures in Kronstadt, Saint Petersburg's fortified island guard city, until the site of disembarkation changed to Oranienbaum on the coast. Upon their arrival in Russia, the immigrants took an oath of loyalty to Empress Catherine and received funds for the continuation of their journeys. An initial group of more than twenty families traveled by land through the Volga region to the southern borderlands of the empire where they arrived in Astrakhan on the Caspian Sea in 1763. Although the Second Manifesto ordered provincial governors to facilitate the settlement of colonists, the governor of Astrakhan informed government officials that a lack of farmland made the area unsuitable for colonists. The lack of compliance from Astrakhan's governor motivated Chancery officials to encourage immigrants to settle in the fertile province of Saratov north of Astrakhan in the Volga region. ${ }^{32}$

Officers from the Chancery guided groups of colonists for nine to eighteen months on the journey to Saratov. The first group of over two hundred people traveled by wagon to Saratov in 1763 , but by 1764 the Chancery determined that the journey incurred excessive expenses and they sent subsequent groups in smaller numbers primarily by

\footnotetext{
${ }^{30}$ Ibid, 47, 103-111.

${ }^{31}$ Scheuerman and Trafzer, The Volga Germans, 45.

${ }^{32}$ Pleve, The German Colonies on the Volga, 111-116.
} 
river. The Chancery paid Russian peasants to house the traveling parties along the way. ${ }^{33}$ Traditional Volga German narrative holds that "thousands were buried en route" on the nearly impossible journey due to extreme weather conditions in the remote interior of Russia. ${ }^{34}$ Pleve confirms that the journey represented "a severe trial" for the colonists, who endured harsh winters and a substantial death rate - an estimated twelve and a half to sixteen percent of the more than twenty-six thousand colonists who traveled to Saratov died along the way.

Government officials prepared living quarters in advance of the settlers' arrival to ensure the success and financial feasibility for the colonization project, but the divergent activities of recruiters who arranged their own colonies disrupted the Chancery's plans. The Chancery allotted lands and funds to purchase lumber, livestock, and tools for the colonists, whose settlements coordinated with their three primary religious denominations: Lutheran, Reform, and Catholic. However, independent recruiters who sought to profit from the colonization project established settlements that lacked the infrastructure and religious organization provided in the government's colonies. ${ }^{35}$ Traditional Volga German narrative holds that the colonists settled on the "barren waste" of the Russian steppe in zemlyanka, earth dugouts covered with grass and mud that they learned to make from Russians peasants. ${ }^{36}$ This anecdote derives from the experiences of one group settled by the recruiter Beauregard, who failed to construct necessary housing

\footnotetext{
${ }^{33}$ Ibid, 117-122.

${ }^{34}$ Weikum, "Oregon Germans That Came From Russia," 9.

${ }^{35}$ Pleve, The German Colonies on the Volga, 122-123.

${ }^{36}$ Richard D. Scheuerman, Pilgrims on the Earth: A German Russian Chronicle (Fairfield, Wash.: Ye Galleon Press, 1974), 36; Williams, The Czar's Germans, 109.
} 
before his first colonists arrived. The settlers spent the first winter in zemlyanka as substitute housing until the government provided funds for the colony. ${ }^{37}$ Missteps by recruiters inconvenienced the government and represented some of the earliest violations of the Second Manifesto, yet the Chancery itself also infringed on colonists' rights in order to aid the imperial endeavor under unanticipated circumstances. ${ }^{38}$

The first group of colonists to settle in Saratov comprised seventeen families who arrived at the hilly Bergseite, the west bank of the Volga River, on June 29, 1764 and settled the original mother colony of Dobrinka. Many more families followed and by 1767 the first wave of settlement concluded with over one hundred established colonies. ${ }^{39}$ Lutherans represented the largest religious order at more than four thousand families. Catholic families numbered two thousand five hundred, and one thousand two hundred and fifty families identified as Reform. ${ }^{40}$ The Chancery created the Kontora of Oversight of Foreigners, a new regional agency based in Saratov, to manage the incoming colonists. The Kontora initially named colonies after Russian landmarks like the Norka River, but as new colonies proliferated the settlers named them after their Vorsteher, mayors who the Chancery appointed among the immigrants to bear local authority in the colonies. Colonies founded by Beauregard featured the names of state officials with whom he sought good relations as in the colony Katherinenstadt, "Catherine's City."

Despite extensive planning and funding by the government, the first years of settlement on the Volga involved significant hardship. Approximately forty percent of the

\footnotetext{
${ }^{37}$ Pleve, The German Colonies on the Volga, 131-132.

${ }^{38}$ Ibid, 116, 139, 161-162.

${ }^{39}$ Scheuerman and Trafzer, The Volga Germans, 43.

${ }^{40}$ Pleve, The German Colonies on the Volga, 139.
} 
colonists practiced specialty crafts such as shoemaking and weaving, but the heavily agricultural economy in the Volga region required significant numbers of non-farmers to convert to peasant labor in order to meet the production quotas of the government. In addition, Chancery officials issued contradictory farming orders due to their lack of agricultural knowledge. The lack of farming experience among some of the settlers combined with unclear instructions and the unfamiliar climate on the steppe led to a series of failed harvests. Settlers in the recruiters' colonies suffered the severest effects of poor agricultural production as some recruiters illegally divided land into plots unsuitable for farming and kept for themselves the funds allotted to colonists for grain, seed, and tools. These colonists petitioned the government for additional loans, and the crown accrued unanticipated debts in order to support the failing colonies. As Pleve writes, the situation for colonists in the early years represented a significant departure from the promises of the Second Manifesto as the theoretically independent farmers "turned into serfs. ${ }^{41}$

Conditions worsened in August 1774 when the Don Cossack Emelian Pugachev, the rebel leader of a peasant revolt, ransacked and burned villages throughout the Volga region. ${ }^{42}$ The Kontora prepared a defense of Saratov and attempted to send money and documents away from the area on a boat, but Pugachev's army intercepted the effort and robbed the vessel. Rebels burned the Kontora's headquarters and raided its grain supply before they rushed through the colonies and stole food, supplies, and livestock. An unknown number of colonists died in the attacks along with several officials of the

\footnotetext{
${ }^{41}$ Ibid, 136-138, 154-159.

${ }^{42}$ Koch, The Volga Germans: In Russia and the Americas, 99.
} 
Kontora. A small number of colonists joined the rebel forces; government records suggest that of the twenty-five thousand colonists on the Volga, forty who participated in the rebellions and survived received punishment. With the majority of the hard-earned food supply from years of difficult harvests gone, the colonists suffered in spite of the extensive assistance provided by government. As Pleve writes, "romantic notions" that the colonists held of themselves as "free people" grew tainted by "memories of terror and destruction" in community memory. ${ }^{43}$

Events like the Pugachev rebellion and a colony's first winter in zemlyanka echo traditional Russian folk tales that portray the Volga region as grim, empty, and vulnerable to plunder. Popular Russian folk songs describe the Volga River as a haven for men who escaped serfdom and traveled the region as robbers and avengers of social justice. These themes are evident in songs such as "Down Along the Mother Volga" and "It Happened Below the City of Saratov," a tale that describes the ambush of Astrakhan's governor:

The river Mother Kamysenka flowed by And behind it ran steep shores, Steep-beautiful shores, green meadows. At its mouth it fell into the Mother Volga.

Along that river Mother Kamysenka Sail the Cossack captain's boats. On these boats sit the oarsmen, All are barge haulers, all are young men of the Volga...

Near an island in the midst of the Volga they stopped: They waited and waited for the governor, For the Astrakhan governor they waited...

They cut off the governor's wild head, They threw the head into the Mother Volga.

\footnotetext{
${ }^{43}$ Pleve, The German Colonies on the Volga, 177.
} 
The young men laughed at him:

"You well know, governor, you have been harsh toward us, You beat us, you destroyed us, sent us into exile, Shot our wives and children at the gates!" ${ }^{44}$

Russian folk lyrics suggest that the Volga region represented freedom to social outcasts, as demonstrated in a song about an orphan raised by the Volga River:

I was nursed and fed by Mother Volga, I was brought up by a light boat of white willow, I was rocked by nana and mama, the fast waves. I was raised by the strange far-off land of Astraxan, And from this land I went on to become a robber. ${ }^{45}$

Russian tales of banditry may derive from the region's lack of serfdom, the primary means of social organization in the empire. As the scholars Scott J. Seregny and Rex A. Wade write, the crown's struggle to control its southern borderlands and the delay in the development of serfdom on the outskirts of the empire "lured religious dissidents, conscripts, and serfs fleeing the exactions of the Russian state." ${ }^{\circ 6}$

Stories of lawlessness in the Volga region precede the establishment of the Russian Empire itself. Mission to the Volga is a first-hand account of the missionary Ahmad Ibn Fadlān's three hundred twenty-five day journey from Baghdad in the Muslim Empire to the Volga region in the year 921. Ibn Fadlān's journey begins when the Muslim king of the Volga Bulghars - a Turkic tribe of the Volga region-seeks instruction from the Baghdad caliph to fortify the Bulghar territory. The caliph agrees to

${ }^{44}$ Russian Folk Lyrics, ed. and trans. Roberta Reeder (Bloomington: Indiana University Press, 1993), 29, 152.

${ }^{45}$ Ibid, 30, 154.

${ }^{46}$ Politics and Society in Provincial Russia: Saratov, 1590-1917," ed. Rex A. Wade and Scott J. Seregny (Columbus: Ohio State University Press, 1989), 2-3. 
help and sends a group of representatives, among them Ibn Fadlān, on a diplomatic mission to the Upper Volga to meet with the Volga Bulghars. Ibn Fadlān describes harsh weather conditions and encounters with many different peoples on the journey including the nomadic and semi-nomadic Ghuzziyyah, Bajanāk, Bāshghird, Rus', and Khazars. He describes an ominous premonition upon his arrival in the Volga Bulghar king's territory:

On our first night in his territory, at what I reckoned was an hour before sunset, I saw the horizon turn a bright red. The air was filled with a mighty uproar, and I heard the din of many voices. I looked up and was surprised to see fiery-red clouds close by. Loud voices came from the clouds, where there were shapes that looked like soldiers and horses... We asked the king about this, and he told us that his forebears used to say, "These are two groups of jinn [spirits], believers and unbelievers, who do battle every evening." He added that this spectacle had occurred every night for as long as they could remember. ${ }^{47}$

Superstitious beliefs about red skies on the steppe also appear in the writings of Jacob E.

Dietz, a Volga German lawyer born in the colony Kratzke in 1864 who warns,

"Prominent heavenly events foretell of special occurrences in the state. An unusually red sky foretells of a bloody war." He goes on to describe the Volga region as a "place of revelry for thieving peoples."

Despite superstitious folk tales from travelers to the steppe, diverse peoples cohabited in the Volga region long before the arrival of Ibn Fadlān, Russian bandits, or Volga Germans. Nomadic and semi-nomadic peoples of the region include Kazakhs, Khazars, Tatars, Volga Bulghars, and Kalmyks. These primarily Turkic groups formed early tribal confederations and by the beginning of the ninth century the Khazar Empire

\footnotetext{
${ }^{47}$ Ahmad Ibn Fadlān, Mission to the Volga, trans. James Montgomery (New York City: NYU Press, 2017), xx, xix, 23.

${ }^{48}$ Jacob E. Dietz, History of the Volga German Colonists, ed. I. R. Pleve and E. R. Yerina (Moscow: Gotika Press, 1997), 24, 375.
} 
controlled the Volga River in a slave trade between the steppe and the Muslim Empire. Under Khazar rule, the Volga River route comprised one of the most important trading networks of the age as goods sourced from the Baltic region and northern Europe crossed the Caspian Sea to reach Muslim cities. ${ }^{49}$ Russians later captured the Volga region from the Tatars of the Ottoman Empire in the mid-sixteenth century, but a substantial population of Volga Tatars remains in the area today. ${ }^{50}$

Volga German narrative typically does not take the history of indigenous groups into account, but it draws on themes from Russian folk tradition to assert that repeated episodes of hardship and violence ultimately contributed to a cultural aptitude for adjustment and perseverance. According to community memory, the Volga Germans' "isolationist attitude" emerged from their experiences on the harsh steppe and informed their unique German-Russian worldview. ${ }^{51}$ This perspective is evident in the Wolga Gesangbuch, a book of hymns central to the heritage of the group. One hymn laments, "Come, children, let us go wander/We go hand in hand/One rejoices with another/In this wild land. ${ }^{, 52}$ A century later many colonists left Russia with little more than clothing, a Bible, and a Gesangbuch, underscoring the desire for a community identity during times of uncertainty.

\footnotetext{
${ }^{49}$ Peter B. Golden, Central Asia in World History (New York: Oxford University Press, 2011), 64-65.

${ }^{50}$ Norman Itzkowitz, Ottoman Empire and Islamic Tradition (Chicago: University of Chicago Press, 1972), 64.

${ }^{51}$ Scheuerman, Pilgrims on the Earth, 97-98.

52 "Kommt, Kinder, lasst uns gehen," Christliche Gedichte, accessed May 3, 2016, http://www.christliche-gedichte.de/?pg=10739.
} 


\section{Chapter II}

\section{To Make Distant Fields Fertile:}

\section{Immigration to the U.S. Midwest}

This chapter examines the series of legal reforms that upended the Volga Germans' privileged colonial status and considers the motivating factors in the group's immigration to the U.S. where their self-constructed ethnic identity took its full form. In a reversal of the ample government aid provided to the colonists during their first decades in the Volga region, the founding principles of the Second Manifesto dissolved with the reorganization of the Russian Empire into a modern state according to nationalist doctrine and the rising social-intellectual Russification movement. Although the years in Russia are typically colored by tales of hardship in community memory, the Volga Germans who immigrated to the U.S. nevertheless maintained strong transnational connections to the colonies and engaged a sense of nostalgia for their shared German-Russian past.

While the first period of settlement in the Volga region from 1764 through 1775 involved significant organizational confusion, poor harvests, and rebellion, the second period beginning in the late 1770 s featured economic prosperity and the stabilization of colonial life. In 1775 the Kontora appealed to Empress Catherine to survey the colonies and reorganize the allocation of funding. The empress authorized the Kontora to evaluate the farming capabilities of every family in the colonies to address rising debts and poor agricultural production. The government hoped to determine the most capable farmers among the colonists in order to direct funds and tools only to those who could successfully contribute to the agricultural effort. As a result of the Kontora's colonial 
survey the Chancery issued plentiful loans, purchased new tools, and provided additional livestock to farmers in 1775 and $1776 . .^{53}$

The government's successful reorganization of colonial funding improved conditions in the colonies. A project to fortify the colonies after the Pugachev rebellion employed poor settlers, and a new system for the management of grain and food stores protected against raids and famine. The Kontora instituted administrative measures to increase development of tobacco and mulberry trees for silk production after years of failed grain harvests. One such measure required couples that wished to marry to plant a certain number of mulberry trees per a pre-nuptial contract. While tobacco remained lucrative in some colonies for decades, costly silk production subsided in the 1780 s. The Chancery shifted its focus to textiles and increased production of sarpinka, a decorative cloth heavily produced in a southern Moravian colony near Astrakhan called Sarepta. The Saratov colonies took up production of thread for sarpinka and colonists who learned how to make the cloth while working in the Sarepta factories introduced its production to Saratov. During this period experiments with the cultivation of grain resumed. While wheat fared better than rye on the left bank of the Volga River, the colonies on the right bank successfully cultivated both grains. The colonists produced substantial amounts of wheat, rye, millet, and corn for trading and they grew oats, potatoes, barley, and peas for use within the colonies. As economic conditions improved and the initial settlement

\footnotetext{
${ }^{53}$ Pleve, The German Colonies on the Volga, 190-191.
} 
period drew to a close, the government reconsidered its financial relationship to the colonists. $^{54}$

After the Kontora provided additional support to stabilize the colonies due to recruiters' mistakes, poor harvests, and the losses of the Pugachev rebellion, the Chancery grew concerned with the accrual of high debt. The bureau issued a broad new mandate on the settlers to declare their collective responsibility for the government's colonization expenses. Krugovaya poruka, the law of collective guarantee, required Russian peasants to share criminal or financial responsibility for the actions of other inhabitants in their region. ${ }^{55}$ This principle of communal responsibility formed the basis of peasant tax law that allowed authority figures to refer debts onto peasants. ${ }^{56}$ The application of Russian peasant tax law to the Volga colonists set the stage for a reconfiguration of colonial management with the onset of economic stability.

Many colonists rejected collective responsibility for government debts on the basis that only some farmers received the last set of loans issued after the Kontora's survey, but the government nevertheless increased pressure for compliance in the colonies. It permitted colonists trained in special trades to pay off debt by working in Russian cities, but those who refused to pay debts despite an ability to work faced punishment or transfer to Astrakhan to perform hard labor. The Kontora enlisted the colonies' own Vorsteher to urge compliance in their villages. When the treasury announced the sum of the debts owed by the colonists in 1785 , the Vorsteher delivered

\footnotetext{
${ }^{54}$ Ibid, 200-209.

${ }^{55}$ Ibid, 189-192.

${ }^{56}$ Trust and Democratic Transition in Post-Communist Europe, ed. Ivana Markova (New York: Oxford University Press, 2004), 89.
} 
the news that the government demanded full reimbursement in twelve years for over five million rubles. Every male in good working health owed thirty to ninety rubles per year for his family, but the treasury soon adjusted the yearly dues as few families could afford to pay even three rubles per year..$^{57}$

The impossible sum demanded of the colonists represented the government's retroactive application of krugovaya poruka to expenses that the Second Manifesto never intended the colonists to repay. The Second Manifesto delineated expenses for which the colonists held responsibility after ten, twenty, and thirty years in Russia, but many of the government's expenses comprised non-returnable debt for which the colonists remained permanently exempt. With the law of collective guarantee in place the treasury recalculated the debt owed by the colonists to include non-returnable debt, an action that voided many of the original stipulations to which colonists agreed when they immigrated.

The dues newly levied on the colonists included reimbursement for the expenses of the colonization campaign including the costs of recruitment, food, and transportation, even for the approximately seven thousand colonists who never settled on the Volga because they died in route or settled elsewhere. The Chancery deemed the colonists responsible for costs associated with the arrival of all the immigrants in Russia and charged them for the transportation and care of over twenty-six thousand settlers in the journey to Saratov, although only twenty-three thousand colonists actually arrived in the region. The Chancery also demanded repayment for the construction of the colonies; the loans to factory owners and manufacturers; and the cost of food, livestock, tools, and all

\footnotetext{
${ }^{57}$ Pleve, The German Colonies on the Volga, 192-194, 212.
} 
other expenses accrued in the colonies after settlement. The Second Manifesto specifies many of these costs as non-returnable debt or does not mention any financial responsibility on the part of the colonists. The decree details settlers' exemption from multiple expenses including those associated with the recruitment and immigration process; the cost of transportation, food, and care during travel in Russia; and the cost of food for the first year of life in the colonies. The Chancery's debt mandate of 1785 not only disregarded these promises of the Second Manifesto, but it also stood as a precursor to legislative acts in the nineteenth century that deconstructed the colonists' protected status. ${ }^{58}$

The reconfiguration of debts on the colonists comprised one of the Chancery's final acts before the imperial government dissolved the colonial oversight bureau and its local agency, the Kontora, in the 1780s on the premise that the colonies no longer required special assistance. The Chancery's original responsibilities involved the management of colonial settlement, but the additional support that the bureau provided to colonists, though necessary under the circumstances, represented a costly transgression of its duties. The colonies fell under the authority of the crown with Empress Catherine's broad organizational reforms of the provinces and the administrative change resulted in a temporary but substantial reduction in direct government involvement in the colonies. The period from the mid-1780s until 1797 represented the closest realization of the Second Manifesto's promise for self-governance, but disparities emerged between the goals of the colonization project and the reality of imperial administration in the

\footnotetext{
${ }^{58} \mathrm{Ibid}, 211-213$.
} 
borderlands. In 1797 the Emperor Peter I, son of Catherine II, decreed the authority of the Second Kontora of Oversight of Foreigners for management of the colonies and all future immigration projects. Despite renewed government oversight, complications arose in the nineteenth century around the restrictions caused by the colonists' debt burden and questions about the division of land.$^{59}$

The pressures of a growing population along with the new financial burden required a revision of land ownership and usage in the colonies. Agrarian law at the time of the colonies' establishment divided according to each male citizen, but under the new authority of the imperial director of economy each household received an equal amount of thirty desyatina of land. Though the government attempted to reduce conflict and eliminate adjustments of land plots with this revision in policy, the amendment highlighted several emerging complications in the colonies including an increase in population density as the new debt burden prevented colonists from obtaining passports to move about the region. Colonists who did have the means to leave their villages tended to stay due to the cultural and linguistic isolation of the colonies. In addition, several families often lived under one roof since most lacked the financial means to construct separate homes. ${ }^{60}$ By 1858 the Volga Germans numbered over two hundred thousand and their settlements spread across Saratov and Samara provinces ${ }^{61}$ Reconfiguration of the land system preceded the establishment of a new wave of Volga colonies to support the

\footnotetext{
${ }^{59}$ Ibid, 299-305.

${ }^{60}$ Ibid, 302-304; Scheuerman and Trafzer, The Volga Germans, 77.

${ }^{61}$ James W. Long, "From Frontier Outpost to Provincial Capital: Saratov, 1590-1860," in Politics and Society in Provincial Russia: Saratov, 1590-1917," ed. Rex A. Wade and Scott J. Seregny (Columbus: Ohio State University Press, 1989), 26.
} 
large population and in the mid-1800s the government designated land for additional daughter colonies on the dry Wiesenseite, the meadow side across the Volga River from the original mother colonies of the hilly Bergseite. ${ }^{62}$

The increased population of the Volga region and the addition of new daughter colonies occurred during a period of social, political, and economic tension in the Russian Empire with the introduction of the intellectual-social Slavophile movement and its rejection of westernization. ${ }^{63}$ In 1861 the government issued a decree to free twentyfive million serfs. Countless popular organizations and revolts surfaced across the empire as social agitation threatened to overrun the goals of the autocracy. ${ }^{64}$ Local civic councils called zemstvos redefined previously "ethnic" colonial territory to reduce isolation and foster peasant enlightenment. ${ }^{65}$ Concurrent with the peasant revolution the Emperor Alexander II issued legal reforms for modernization in line with the doctrine of Russification, a nationalist assimilation campaign. Foremost among these reforms is the edict known as the 1871 Ukase and its key amendment released in 1874.

The Ukase established a new legal framework to unify the population of the modern Russian state, but the change constituted a regression to the colonists as it dissolved the framework around their privileged status. The edict terminated the Saratov Office for the Guardianship of Foreign Settlers and abolished the kolonisty, the special

${ }^{62}$ Scheuerman and Trafzer, The Volga Germans, 77; Scheuerman, Pilgrims on the Earth, 53; For a map of the Volga German colonies, see Figure 2 in Appendix A, p. 92.

${ }^{63}$ Williams, The Czar's Germans, 161.

${ }^{64}$ Scheuerman and Trafzer, The Volga Germans, 92; Alan Kimball, "Conspiracy and Circumstance in Saratov, 1859-1864, in Politics and Society in Provincial Russia: Saratov, 1590-1917," ed. Rex A. Wade and Scott J. Seregny (Columbus: Ohio State University Press, 1989), 48.

${ }^{65}$ Long, "From Frontier Outpost to Provincial Capital," 141. 
legal identity of colonists. The act legally and socially reclassified the colonists as poselianin-sobstvennik, land-holding Russian peasants, and it mandated the use of the Russian language in administration of the colonies. ${ }^{66}$

In 1874 the government announced a law for universal military conscription in order to align the populace into a single Russian class - an event often cited in Volga German narrative as the deciding factor in the group's emigration out of Russia. An analysis of this amendment fine-tunes the popular idea that the Volga Germans left Russia due to a strong cultural objection to military conscription and reveals a more nuanced reality. The 1871 Ukase granted colonists the right to leave Russia within ten years and required only limited debt repayment, but no colonists emigrated until after 1874 with the launch of universal military conscription. However, the small number of colonists who emigrated immediately after the introduction of military conscription does not reflect the degree to which this event is emphasized in traditional Volga German narrative as only two percent of the colonial population left Russia between 1874 and 1881 when conscription required an average of five hundred young single men per year. The primary wave of Volga German emigration occurred after 1904 when twenty to twenty-five percent of male colonists, most of whom belonged to the reserve forces, faced the call to serve in the Russo-Japanese War. The scholar James W. Long describes the unpopularity of the war and the community's reaction to the broad mobilization of reserve forces as "erroneously" conflated with total rejection of military conscription. ${ }^{67}$

\footnotetext{
${ }^{66}$ Scheuerman and Trafzer, The Volga Germans, 93; Long, "From Frontier Outpost to Provincial Capital," 142.

${ }^{67}$ Ibid, 139, 151-153.
} 
Traditional Volga German narrative holds that government mismanagement of the colonies and the oppressive forces of Russian assimilation threatened core community values of autonomy and freedom from military service, yet the historical record paints a more complex picture in which government intervention remained necessary for the early survival of the colonists and threats to their autonomous status came only with the dissolution of imperial administration during the modernization of the state. The violation of the Second Manifesto's promise for self-governance nevertheless looms large in Volga German memory where Empress Catherine is continually benevolent and other government officials are unresponsive to the colonists' plight. A Volga German song entitled "Des Schoene Garden" highlights the romanticization of Empress Catherine and her special benevolence for the German settlers in community memory:

There was a beautiful large garden, Few trees stood in it.

A great gardener

Diligently took care of it.

She wanted it more beautiful,

She fetched trees from afar.

Russia is the large garden, And the Germans who gathered Upon the call of the empress Are the trees of the foreign land, Both sides of the Volga bank. ${ }^{68}$

Nostalgia and nature often feature as dual themes in Volga German folk songs and poems, and the spirit of remembrance is either peaceful or sorrowful. Volga German poet

${ }^{68}$ Bev Krein, "German Colonists in Russia." Germans From Russia Heritage Collection, last modified October 27, 2017, https://library.ndsu.edu/grhc/research/scholarly/meetings_conventions/krein.html. 
Peter Sinner uses this pairing to express sorrow in his 1927 poem entitled

"Herbstgedanken," Autumn Thoughts:

A leaf, taken from the mother bough, is given over to weather, storm and wind. It flies, only to come to rest until it moulders away, covered with snow...

You return, o leaf, to earth; and to make distance fields fertile is the misfortune of my people.

Your destiny, oh little dying leaf, is to go up in ashes; and so I would like to see you, oh weary leaf, sink into your own forest. ${ }^{69}$

Volga German nostalgia always harkens back to a romantic past. Community narrative posits that when the first Volga German immigrants settled on the Great Plains in the U.S. - an environment reminiscent of the Russian steppe - the social, political, and economic conditions of the New World quickly posed a threat to Old World life.

This examination of the historical record reveals that the Germans originally took up settlement in Russia based on guarantees for autonomous governance, religious freedom, exemption from military service, and the opportunity to participate in an economic project sponsored by the crown with limited repayment required, yet the government rescinded a majority of these promises a century later in a series of legal reforms to transform the feudal empire into a modern state. The reality of the colonial project proved more complex than both the settlers and the Russian diplomats expected as necessary government intervention violated core provisions of the Second Manifesto, but neither the colonists nor the imperial government anticipated the expansive Russification reforms that nullified the framework around the colonists' privileged status

${ }^{69}$ Peter Sinner, Germans in the Land of the Volga, trans. Dona Reeves-Marquardt (Lincoln, Neb: American Historical Society of Germans from Russia, 1989), 55. 
in the nineteenth century. As policies in Russia radically changed, some colonists looked elsewhere for a promising life. They set their sights on the U.S., which promoted religious and political freedom and offered settlers economic opportunities with the 1862 Homestead Act:

Any person who is the head of a family, or who has arrived at the age of twenty-one years, and is a citizen of the United States, or who shall have filed his declaration of intention to become such, as required by the naturalization laws of the United States, and who has never borne arms against the United States government or given aid and comfort to its enemies, shall, from and after the first January, eighteen hundred and sixty-three, be entitled to enter one quarter section or a less quantity of unappropriated public lands. ${ }^{70}$

The Volga Germans, who gained significant farming experience through a century of primarily agricultural work on the Russian steppe, settled on public lands in the U.S. West where they performed the first iteration of their identity as German-Russian immigrants.

Unique research challenges arise in this area of Volga German history due to differences in the availability of archival records that document the settlers in Russia and in the U.S. Pleve utilizes Russian government documents to establish a clear overview of early Volga German colonial history through the settlers' own easily identifiable category in the legal framework of the imperial colonization project, but colonists who immigrated to the U.S. no longer possessed a specific category of identity. Volga Germans in the U.S. are featured in both German and Russian immigrant records and familiarity with their

\footnotetext{
${ }^{70}$ Library of Congress, "An Act to secure Homesteads to actual Settlers on the Public Domain," A Century of Lawmaking for a New Nation: U.S. Congressional Documents and Debates, 1774 - 1875 (Statutes at Large, 37th Congress, 2nd Session), 392.
} 
history is often required in order to identify them within the archives. The foremost clue that indicates a Volga German archival finding is the attribution of Russian nationality and German language in census records. However, this method raises further questions around the distinction of German-Russian immigrants of divergent origins. While all Volga Germans are German-Russians, not all German-Russians lived in the Volga colonies as some lived in Russian cities or belonged to the Black Sea colonies.

Despite significant archival challenges in the study of German-Russian immigrants in the U.S., several books and articles produced by scholarly descendants of these immigrants offer compelling accounts of this history including Emma S. Haynes' German Russians on the Volga and in the United States; Richard Sallet's RussianGerman Settlements in the United States; and Timothy J. Kloberdanz's "Symbols of German-Russian Ethnic Identity on the Northern Plains.." ${ }^{\text {"1 }}$ Additionally, many GermanRussian families collect extensive heritage materials that are accessible through organizations such as the American Historical Society of Germans from Russia (AHSGR) in Lincoln, Nebraska and the Germans from Russia Heritage Collection (GRHC) at North Dakota State University in Fargo. The research process for analysis of German-Russian history in the U.S. involves cross-referencing traditional community narratives, published works, and heritage materials with available archival sources such

\footnotetext{
${ }^{71}$ Emma S. Haynes, German Russians on the Volga and in the United States (Lincoln, Neb: American Historical Society of Germans from Russia, 1996), originally submitted as the author's MA thesis, University of Colorado, 1927; Richard Sallet, Russian-German Settlements in the United States (Fargo: North Dakota Institute for Regional Studies, 1974); Timothy J. Kloberdanz, "Symbols of German-Russian Ethnic Identity on the Northern Plains," Great Plains Quarterly 8 (Winter 1988).
} 
as census lists and newspaper articles. The post-Russia Volga German narrative ultimately remains a mosaic of pieces for the historian to compose.

In community memory the first Volga Germans to immigrate to the U.S. are thought to be Johann Adam and Matthias Repp, brothers who remained closely connected to their community in Russia and recruited their brethren to join them in the New World. ${ }^{72}$ The brothers lived in an upper Volga colony originally founded in 1767 called Jagodnaja Poljana, Berry Meadow. ${ }^{73}$ The brothers settled on a homestead in Kansas in 1855 , but due to unrest surrounding the Civil War they returned to Russia to locate their families. Little else is known about the brothers or their experiences in the U.S., but it is said that Johann Adam encouraged his family along with two hundred other colonists to join him in the return to Kansas in $1876 .^{74}$

The first documented wave of German-Russian immigration to the U.S. occurred among the German Mennonite colonists who established an initial transnational connection to the U.S. Midwest that formed the basis of subsequent Volga German migration. The Mennonites, whose strict minority-sect religion specifically rejected military service, lived in colonies near the Black Sea in southern Russia. In 1872 a petition sent from the Mennonite colonists to a U.S. consul inquired about the subject of immigration. The consul replied with information about the Northern Pacific Railroad, a project that offered immigrants plots of land in the West and employment in railroad

\footnotetext{
${ }^{72}$ Scheuerman and Trafzer, The Volga Germans, 79.

73 "Yagodnaya Polyana," Center for Volga German Studies, last modified November 19, 2015, http://cvgs.cuportland.edu/settlements/mother_colonies/colony_yagodnaya_polyana.cfm. ${ }^{74}$ Scheuerman and Trafzer, The Volga Germans, 79.
} 
construction. In the same year twenty-one Mennonite families from the Black Sea region immigrated to Ohio and Dakota Territory. On July 1, 1874 the first group of fourteen Catholic and Protestant Volga Germans set sail from Hamburg aboard the S. S. Schiller en route to the U.S. ${ }^{75}$ They arrived in Nebraska where they connected with a group of Black Sea Mennonites who migrated there from a previous settlement in Dakota Territory. ${ }^{76}$

Kansas and Nebraska comprised the focal points of early German-Russian life in the U.S. as the settlers organized according to the familiar social models of their colonies in Russia. They settled in groups based on their religious affiliations and the margins of their communities grew conspicuous to other local inhabitants. ${ }^{77}$ A 1907 article in the Nebraska State Journal states that German-Russian settlers in Lincoln maintained distinct community boundaries and demonstrated strong cultural customs: "In the north and west of Lincoln there are about 2,000 German-Russians. The settlements which they inhabit have few other nationalities in them. The people live a life that is distinctly their own... Here they retain many of the manners and customs of their forefathers.” A 1914 article from the Lincoln Journal Star notes that inhabitants of Lincoln "playfully alluded to" the German-Russian community as "Little St. Petersburg." "78 The general population remained confused about the ethnic and national origins of the German-Russian immigrants, who they often classified as Russians despite their German dialect.

\footnotetext{
${ }^{75}$ Ibid, 79, 95 .

${ }^{76}$ Weikum, "Oregon Germans That Came From Russia," 10.

${ }^{77}$ Kloberdanz, "Symbols of German-Russian Ethnic Identity on the Northern Plains," 5.

78 “Lincoln's German Russians," Nebraska State Journal, 3 February 1907, https://www.newspapers.com; "German-Russian Colony Evidence of City's Growth," Lincoln Journal Star, 23 October 1914, https://www.newspapers.com.
} 
The German-Russians' identity breached familiar immigrant categories from their first arrival on the Great Plains. They dressed as Russian peasants in sheepskin coats, black or colorful flowered shawls, and high felt boots, yet they spoke an old form of regional German with small additions of Russian words and phrases. While their German language plainly differentiated them in Russia, their dialect did not clearly identify them in the Midwest with the region's significant population of Reichsdeutsche, Germans from Germany. ${ }^{79}$

Although their dialect did not identify them to the general population, the German-Russian immigrants nevertheless utilized language as a cultural symbol to facilitate solidarity in their community, create a sense of belonging, and maintain transnational connections during the period of settlement in the U.S. Midwest. Language helped to mitigate the differences that existed among German-Russians who settled in the U.S. Some emigrated from the Black Sea colonies and others from the Volga colonies; some identified as Catholic and others belonged to Protestant denominations ranging from Lutheran and Reformed to Moravian Brethren. The German-Russians' common language connected their communities in the Great Plains and formed the basis of a unifying symbol, the Dakota Freie Presse. The German-language newspaper, established in 1874 in Yankton, Dakota Territory, provided a nondenominational link between German-Russian settlers of various colonial and religious affiliations. The publication featured discussions on the background of the German-Russians, reported on family connections, and provided information about local opportunities and resources. A 1914

\footnotetext{
${ }^{79}$ Kloberdanz, "Symbols of German-Russian Ethnic Identity on the Northern Plains," 5-6; Kinbacher, "Life in the Russian Bottoms," 27.
} 
article in the Buffalo Enquirer quotes the editor of the Dakota Freie Presse at that time, J. F. Paul Gross, in a statement that the newspaper comprised " the recognized organ of the German Russian American." ${ }^{\prime 80}$ The publication fostered a communal spirit based in shared language and transnational connections to bond various German-Russian settlements of the Midwest under a common identity.

The collective spirit that linked German-Russians through the Dakota Freie Presse is also evident at the individual settlement level where communal operation remained a vestige of colonial life. Community members forged transnational connections between their "new" U.S. colonies and their "old" Russian ones by writing letters and sponsoring the immigration of their family members and neighbors. They consulted as a group when an individual wished to purchase a farm, and when unsuccessful farmers sold their land and temporarily took jobs in railroad construction until they gained the ability to purchase land better suited for farming - particularly in northern Colorado and the Pacific Northwest—often a small community transplanted itself on the individual's new land ${ }^{81}$ While some German-Russians assimilated into the larger Reichsdeutsche population of the Midwest, many others maintained enclaves with strong linguistic and cultural links to their home colonies even as Germans comprised the largest immigrant group in the nation from 1861 to $1890{ }^{82}$

\footnotetext{
80 “Would Not Suit Viereck," Buffalo Enquirer, 30 July 1917, https://www.newspapers.com.

${ }^{81}$ Tony Waters, "Towards a Theory of Ethnic Identity and Migration: The Formation of Ethnic Enclaves by Migrant Germans in Russia and North America," International Migration Review 29, no. 2 (Summer 1995), 534-535.

${ }^{82}$ Bade, "From Emigration to Immigration," 511.
} 
The immigration of approximately five and a half million Germans to the U.S. from 1816 to 1914 occurred in the age of mass global migration with the expansion of the global political economy. ${ }^{83}$ Social and familial networks formed transnationally and lay parallel to economic and industrial networks that grew globally as the major forces of migration. ${ }^{84}$ The homesteads where many immigrants settled in the U.S. West did not exist in the isolation of the frontier as Turner's theory suggests, but rather in direct connection with imperial aims and within the broader global economic context.

The U.S. imperialist doctrine of Manifest Destiny, a framework for the justification of westward expansion, established the rhetoric that informed legislation around migration and settlement as evidenced in the Homestead Act of 1862. The law granted large plots of land to immigrants who wished to become U.S. citizens and required that they cultivate the land for five years to achieve ownership. Immigrants also acquired land along the paths of the railroads through subsidized deals between the railroad companies and the government, and settlers who obtained work in railroad construction enjoyed the benefit of discounted railroad tickets as further incentive to travel west. ${ }^{85}$ Transportation companies heavily linked to institutions in the eastern U.S. capitalized on the era of mass migration to increase passenger service on the railways and

\footnotetext{
${ }^{83}$ McKeown, "Global Migration, 1846-1940," 155-157; Samuel M. Otterstrom and Carville Earle, "The Settlement of the United States from 1790 to 1990: Divergent Rates of Growth and the End of the Frontier," Journal of Interdisciplinary History 33, no. 1 (Summer 2002), 166-167.

${ }^{84}$ Suzanne M. Sinke, "Crossing National Borders: Locating the United States in Migration History," OAH Magazine of History 19, no. 3 (May 2005), 59.

${ }^{85}$ Scheuerman, Pilgrims on the Earth, 97.
} 
to ensure profits from the shipment of industrial and agricultural commodities produced by settlers in the West. ${ }^{86}$

The development of promotional partnerships between state governments and railroad companies to recruit immigrants to settle in the West is exemplified in a promotional report created by the Oregon State Board of Immigration and the Oregon Railway and Navigation Company. Published in a range of different languages, the 1881 report advertises a newly opened railroad line to Portland and endorses the natural conditions of the Northwest as suitable for settlers. It declares, "The Pacific States possess natural advantages far superior to those of any of the Eastern, Western, or Southern States... They are, indeed, among the most favored lands on the face of the globe, and certain to develop into great and prosperous commonwealths." The report extolls the high soil quality in Oregon, an attractive prospect for many immigrants of farming background: "Western Oregon is unquestionably the finest farming country in the United States...The leading staple of Oregon is wheat, which is noted for its superior quality and large yield, and commands a high price." The report defines the ideal Pacific Northwest settler and calls on immigrants with certain industrious traits:

"Persons accustomed to ordinary and mechanical labor, and who unite frugal habits with persevering industry, will run the least risk in emigrating to Oregon; but individuals unwilling to work, or unaccustomed to live by their wits, are not wanted in Oregon... Success may be achieved by capable men, prepared for years of patience and self denial." ${ }^{, 27}$

\footnotetext{
${ }^{86}$ Pomeroy, "Toward a Reorientation of Western History," 581; Scheuerman and Trafzer, The Volga Germans, 118.

${ }^{87}$ Oregon State Board of Immigration, Oregon: Facts regarding its climate, soil, mineral and agricultural resources, means of communication, commerce and industry, laws, etc., etc., for general information (Boston: Oregon State Board of Immigration, 1877), 1, 17, 43.
} 
The conditions of high agricultural productivity and the modernization of transportation and industry in the U.S. combined with local and global forces of migration to set the stage for the Kansas and Nebraska Volga Germans' migration from the Midwest to the Pacific Northwest.

The revocation of the Volga Germans' privileged colonial status in Russia compelled the impulse for community preservation that informed their social organization in the Midwest. The rise of a new unified German-Russian identity among the immigrants served to bridge differences in colonial origin and religion that otherwise set them apart. Settlers often maintained transnational ties to the Russian colonies and kinship compelled many colonists to join their friends and family members in the U.S. The performance of German-Russian identity in the Midwest laid the groundwork for the Volga German practice of nostalgia as a strategy to maintain community cohesion in the absence of other clear markers of identity. 


\section{Chapter III}

\section{Every Beginning Has an End: Assimilation in Albina}

This chapter analyzes the ways in which Portland's Volga Germans took action to establish a local community identity within the larger German-Russian transnational network even as traditional markers of their culture including language, dress, religion, and agricultural lifestyle faded away with assimilation in the twentieth century. I utilize materials provided by a local Volga German descendant, Steve Schreiber, in addition to newspaper articles and census records to propose that the Portland Volga Germans' possession and loss of a privileged colonial status in Russia compelled the reassertion of a unique identity that ultimately manifests as nostalgia for a shared past.

Though the Volga Germans who settled in Albina in 1881 comprised the first German-Russian settlers in the Pacific Northwest, no scholarly books or articles currently focus on this history. The Albina settlement is briefly mentioned in several scholarly works that provide valuable context for this history including Richard Sallet's RussianGerman Settlements in the United States published by the North Dakota Institute for Regional Studies and Richard D. Scheuerman and Clifford E. Trafzer's The Volga Germans: Pioneers of the Northwest published by the University Press of Idaho, but a thorough scholarly analysis of the Albina settlement remains to be written. The vast majority of information available about the settlement and development of the Albina community is found in the work of Schreiber, whose research and extensive collection of primary documents and heritage materials is accessible on his websites The Volga 
Germans in Portland and Norka, Russia ${ }^{88}$ As both a local community member and a specialist of Volga German studies broadly, Schreiber provides essential evidence for any study of the community's history in Portland.

The original settlers of the Albina Volga German community migrated from the Midwest where difficult environmental conditions threatened their livelihood, according to traditional narrative. As the Black Sea German-Russian descendant Mary Koellermeier Weikum writes in a 1977 article for the Bulletin, "times were hard" for settlers of the Midwest as the "weather was bad" and conditions remained "not conducive to rearing a family." ${ }^{89}$ Tornadoes and severe weather endangered settlers, and crops failed in Kansas amidst a grasshopper plague in the late 1870s that destroyed fields just as the Midwest experienced a drought. ${ }^{90}$

Historical evidence supports the point that the settlers faced difficult conditions on the Great Plains in some years. An 1888 article in the Emporia, Kansas newspaper the Evening News refers to "seasons of drought, so often occurring, and so injurious to our summer crops," while another article published in 1887 in the Kansas newspaper the Winchester Argus declares, "ALMOST TOO LATE. The Great Drought Fully Broken.” It reports a break in the drought affecting the Midwest and characterizes corn and potato crops as "generally badly damaged." A locust plague is referenced in an 1877 article from the Weekly Commonwealth of Topeka, Kansas. The article reports on a field of rye stripped by locusts "attacking the young and tender heads as fast as they appear." The

\footnotetext{
${ }^{88}$ Steve Schreiber, The Volga Germans in Portland, https://www.volgagermansportland.info/; Schreiber, Norka, Russia, https://www.norkarussia.info/.

${ }^{89}$ Weikum, "Oregon Germans That Came From Russia," 8.

${ }^{90}$ Scheuerman and Trafzer, The Volga Germans, 117.
} 
article also notes "rumors" in nearby counties about "fields being destroyed." 91 Unfavorable conditions in the Great Plains emerged just as transportation companies recruited immigrants to build railroad links to the Pacific Northwest in an economic project that bolstered territorial expansion of the U.S. to the Pacific Coast.

Transportation companies collaborated with the U.S. government to develop the far West in order to produce more commodities and grow profits from increased shipments and rail passenger service. In 1875 the Oregon Commissioner of Immigration, a Bavarian-born journalist and businessman named Henry Villard, opened agencies in Nebraska and Kansas to offer immigrants reduced travel rates to the Pacific Northwest if they agreed to perform railroad labor for transportation companies or purchase farmlands from them. By 1877 Villard gained control of the Northwestern transportation network through his presidency of the Oregon and California Railroad, the Oregon Central Railroad, and the Oregon Steamship Company that operated between San Francisco, California and Portland, Oregon. ${ }^{92}$

In the same year the U.S. government ordered a survey of travel routes in the West. The Brevet Brigadier-General James F. Rusling, who authored the report, characterizes Portland as the "first city of importance north of San Francisco, and the brain of our northwest coast." He notes Portland's position as the headquarters of powerful transportation companies including the "great Oregon Steam Navigation

\footnotetext{
91 "How Drought Benefits the Soil," Evening News, 3 February 1888, https://www.newspapers.com; "Almost Too Late: The Drought Fully Broken: Refreshing Showers," Winchester Argus, 18 August 1887, https://www.newspapers.com; "Capitol Notes," Weekly Commonwealth, 05 July 1887, https://www.newspapers.com.

${ }^{92}$ Scheuerman and Trafzer, The Volga Germans, 117, 122.
} 
Company," an entity that controlled steamboats on the Columbia and Snake Rivers and connected "all the rich trade of the Columbia and its far-reaching tributaries, that tap Idaho, Montana, and even British America itself." Rusling describes Portland as the nineteenth century gateway to "thousands of miles of territory and trade, in all directions," a vision dependent on an infrastructure built with immigrant labor. ${ }^{93}$

Developers established a railroad town called Albina on the northeast bank of the Willamette River across from Portland in 1873 as part of a project to connect the Willamette Valley and Sacramento, California. An 1874 recession delayed the project until another set of developers purchased Albina in 1879 and established its industrial infrastructure. Dominated by the Oregon Railroad and Navigation Company, Albina's property values and population grew quickly and the town stood as an example of the powerful business interests converging in Oregon with the completion of the transcontinental railroad link in $1883 .^{94}$ Albina's rapid growth as a railroad company town is evidenced in an 1888 article from the Morning Oregonian. The column challenges any who doubt that "Albina's population will be more than fifteen-thousand within four years" and further asserts, "the state of Oregon is fast filling up and will

\footnotetext{
${ }^{93}$ James F. Rusling, The Great West and Pacific Coast; or, fifteen thousand miles by stage-coach, ambulance, horse-back, railroad, and steamer-across the continent and along the Pacific Slope-through the Rocky Mountains, down the Columbia River, over the Sierra Nevadas-among Indians, Mormons, miners and Mexicans, report compiled for the U.S. Government (New York: Sheldon \& Company, 1877), 265.

${ }^{94}$ Steve Schreiber, "A Short History of Albina," The Volga Germans in Portland, last modified February 16, 2018, https://www.volgagermansportland.info/a-short-history-ofalbina.html; Roy Roos, "Albina area (Portland)," Oregon Encyclopedia, last modified December 17, 2017, http://www.oregonencyclopedia.org/articles/albina_area_portland_/\#.V0CkbpMrJ8c.
} 
double her population in ten years. ${ }^{995}$ In much the same way that their ancestors in the Holy Roman Empire responded to recruiters' efforts to induce migration to the Russian Empire, some German-Russians of the Midwest responded positively to the incentives offered by transportation developers who hoped to utilize immigrants to develop Oregon. Evidence suggests that three Kansas Volga German parties from several daughter colonies of Norka and Jagodnaja Poljana comprised the first group of German-Russians to migrate to the Pacific Northwest in 1881. The first of the three parties sailed to the U.S. on the S.S. Ohio and settled in Kansas in 1875. A small second party boarded the S.S. Montreal and joined the first party in Kansas in early 1876. A third larger party of at least two hundred Volga Germans traveled aboard the S.S. Mosel and settled in Kansas in late 1876. The three parties of common origin formed a new single Kansas colony in Rush and Barton Counties. In 1881 the Kansas colony took advantage of reduced immigrant fares to travel on the Union Pacific Railroad to San Francisco, California where they set sail for Portland aboard a vessel owned by the Oregon Steamship Company. The group settled in Lower Albina that year, and the men took labor jobs at the lumber mill and constructed the Albina fill for the Oregon Railway and Navigation Company. ${ }^{96}$

The second group of Volga Germans to immigrate to the Pacific Northwest came from the Russian colonies of Kolb, Frank, Messer, and Walter and they settled in Hitchcock County, Nebraska, before they migrated to Washington Territory in 1882. In

95 “Oh! This Busy World,” Morning Oregonian, 9 May 1888, https://www.newspapers.com.

${ }^{96}$ Steve Schreiber, "Migration to Portland," The Volga Germans in Portland, last modified February 16, 2018, http://www.volgagermansportland.info/migration-toportland.html; Scheuerman and Trafzer, The Volga Germans, 131. 
1880 the Nebraska colony wrote to a railroad immigration agent for the Oregon Railway and Navigation Company to inquire about the availability of reduced travel fare and the quality of farmlands in Washington Territory. The colony received a response in 1882 that affirmed their hopes to settle in the Pacific Northwest and they boarded the Union Pacific Railroad from North Platte, Nebraska to Ogden, Utah. They continued the journey from Utah to Washington Territory along the California and Oregon Trails in wagons. Along the way, some among the group found temporary labor work on the unfinished railroad line that connected Wyoming to the Pacific Northwest. When they reached eastern Oregon, a few members of the group diverted to join the Albina settlement while the rest continued the journey to Walla Walla, Washington Territory.

In 1882 some members of the Walla Walla settlement traveled to Ritzville in Washington Territory where the businessman Phillip Ritz employed them to work on his land while he developed a plan with railroad officials to recruit immigrants to settle the Palouse, a rural area east of Ritzville formed from rich fertile silt. In that year a small contingent of Albina Volga Germans traveled by wagon to a section of the Palouse near Endicott in Whitman County where the men found construction work on the Northern Pacific Railroad line. A strong connection grew between eastern Washington and the Midwest as more German-Russians joined the Palouse colony in Whitman County by $1883 .^{97}$

In the early years of settlement the Albina Volga German community contained twenty families and comprised the area from Northeast Morris Street in the north to Northeast Tillamook Street in the south, and from Northeast Union Avenue- now Martin

${ }^{97}$ Scheuerman and Trafzer, The Volga Germans, 104, 131-140, 147. 
Luther King Boulevard - in the west to Northeast Seventh Avenue in the east. Over the next years the community began to take a new shape with the continual migration of Volga Germans to the area. An 1889 article from the Morning Astorian reports on the arrival of "seventeen German Russian families" who traveled from Dakota Territory to Albina. Another group of approximately fifteen families arrived in $1890 .{ }^{98}$ As the city grew, it expanded to the boundaries of Northeast Alberta Street to the north, North Russell Street to the south, North Mississippi Avenue in the west, and Northeast Fifteenth Avenue in the east. ${ }^{99}$

A business district emerged in Albina along Northeast Union Avenue from Fremont Street to Shaver Street. Popular shops included the grocery and meat markets Repp Brothers, Hilderman's, and Krumbein's. ${ }^{100}$ Some members of the community who specialized in craftsmanship built homes. Others fashioned goods for Weimer's Hardware and Furniture and the Doernbecher Furniture Company. ${ }^{101}$ A large number of Volga German men known as scavengers worked in the independent garbage collecting business. A 1911 article in the Oregon Daily Journal reports "104 licensed scavengers" in the city, and census records reveal many Russian-born German speakers of scavenger

\footnotetext{
98 "Clipped and Condensed: News Items From all Over the Northwest," Morning Astorian, 26 November 1889, https://www.newspapers.com; Steve Schreiber, The Volga Germans in Portland, "Little Russia," https://www.volgagermansportland.info/littlerussia.html.

${ }^{99}$ Marie Krieger, "The Portland Community of Russian Germans," Journal of the American Historical Society of Germans from Russia 10, no. 3 (Fall 1987), 33; For a map of Portland, see Figure 3 in Appendix A, p. 93.

${ }^{100}$ Ibid, 34-35; Polk's Portland City Directory, vol. 1939, LXXIV (Portland: R. L. Polk \& Co., 1939), 1150-1151.

${ }^{101}$ Karl Klooster, "Round the Roses: Notes and Anecdotes," This Week Magazine (October 28, 1987), 1.
} 
occupation. Conrad Hohnstein, whose birthdate is listed as approximately 1877 in Russia, immigrated in 1906, lived at Northeast Mallory Avenue, and is listed in the 1910 U.S. Federal Census as a scavenger by occupation; George Blum, born in about 1879 in Russia, immigrated in 1900, lived on Northeast Rodney Avenue, and worked as a scavenger; John Hinkle, born in approximately 1882 in Russia, immigrated in 1907, resided at Northeast Twelfth Avenue, and also worked as a scavenger. The 1910 Census continues in this fashion for many pages as dozens of German names organized by Russian birthplace list the words "scavenger" and "wagon" for occupation and industry. $^{102}$

Census records demonstrate the vague space that the Volga Germans occupied between the "German" and "Russian" immigrant categories, and Portlanders typically sidestepped the confusion by referring to the community as Little Russia. A 1921 article in the Oregon Daily Journal reports on a library that served the "'Little Russia' of the Alberta district" in Albina. A Volga German descendant named Marie Krieger, one of the most prominent community members in the Pacific Northwest who collected and translated an abundance of Volga German heritage materials, refers to the Albina settlement as "Little Russia" in her 1987 article, "The Portland Community of Volga Germans" for the Journal of the American Historical Society of Germans from Russia. In a 1987 column by Karl Klooster in This Week Magazine the journalist describes how he "incurred the wrath" of Volga Germans "as far away as Arizona" when he attributed the

\footnotetext{
102 "Fly Is Menace to Public's Health; Swat Him Hard: House Pest Killed More American Soldiers During Spanish War Than Bullets of the Enemy; How to Fight Insect," Oregon Daily Journal, 4 June 1911, https://www.newspapers.com; U.S. Census Bureau, 1910 United States Federal Census, https://www .ancestry.com.
} 
name "Little Russia" to South Portland's Russian Jewish community rather than the "close-knit community across the river in Albina."103

The term Little Russia is also observed in the Midwest where the general population used the same name to refer to German-Russian communities. A 1905 article in the Spokane Press with special correspondence from Hays, Kansas reports that Ellis County "might as well be called 'Little Russia"” as three-quarters of its twelve thousand inhabitants immigrated from Russia and found that "the farm life is almost the same as that on the steppes." The Topeka State Journal of 1911 features an announcement that reads, “'Little Russia' People Raise $\$ 500$ to Send Friends” and reports on community efforts to support Jacob Applehans and Adam Artzer, who "left Saratow, Russia" in the prior year. Another article about the local German-Russian community in the Topeka Daily Capital of 1915 mentions a "Russian blacksmith" named George Schmidt who attended a "wedding in Little Russia." A 1902 article in the Nebraska State Journal reports on floods in Topeka that displaced "inhabitants of 'Little Russia."” Nebraska's own Little Russia is referenced in a 1906 article from the Omaha Daily Bee that observes, "It is probable Little Russia will again be flooded as it was three years ago." Thus the name Little Russia not only identifies Albina in historical memory, but also connects it to the national network of German-Russian communities in the U.S. ${ }^{104}$

103 “Know Your Portland,” Oregon Daily Journal, 2 February 1921, https://www.newspapers.com; Krieger, "The Portland Community of Russian Germans," 34; Klooster, "Notes and Anecdotes," 1.

104 "Why Russian Farmers in Kansas Flopped to the Republicans," Spokane Press, 11 September 1905, https://www.newspapers.com; "North Side News," Topeka State Journal, 9 June 1911, https://www.newspapers.com; “A Day's Town News," Topeka Daily Capital, 6 November 1915, https://www.newspapers.com; "Lincoln Gets Drenching," Omaha Daily Bee, 2 July 1906, https://www.newspapers.com. 
Just as the name Little Russia links Albina to the wider German-Russian presence in the U.S., the appearance of the German Congregational Church in Albina by the end of the nineteenth century united local Volga Germans with other community members across the U.S. A Prussian missionary of the American Congregational Church established the first German Congregational Church in 1873 in Sutton, Nebraska. News of the church spread to the Black Sea Germans of Dakota Territory and by 1874 the church organized several parishes into a Nebraska-Dakota District. Soon afterward a Volga German preacher active in the Ritzville, Endicott, and Albina settlements established the first German Congregational parishes in the Pacific Northwest. While some German-Russians in the U.S. remained Lutheran, Reformed, Brethren, or Catholic, the German Congregational Church grew into a popular alternative with its almost entirely German-Russian leadership and membership. ${ }^{105}$

The German Congregational Church represented an institution through which German-Russians organized principles of community life and demonstrated solidarity. As a 1913 article from the Oshkosh Northwestern of Wisconsin reports, German Russians in that city "asked permission to organize a church of their own" so that they would be “certain of freedom of worship." Referenced as the "Russian German Congregational Church," the Oshkosh congregation grew to two hundred and twenty members within a year and maintained the necessity "to hold services in their native tongue."106 Use of the

\footnotetext{
${ }^{105}$ Sallet, Russian-German Settlements in the United States, 90; Steve Schreiber, "First German Congregational Ebenezer Church," The Volga Germans in Portland, last modified February 15, 2018, http://www.volgagermansportland.info/ebenezer-germancongregational-church.html.

106 "Lay a Cornerstone: Building of New Russian German Congregational Church Formally Dedicated Sunday, Professor Meske of Chicago Theological Seminary
} 
traditional language remained a central factor in German-Russians' desire to join the church and acted as the most powerful symbol of solidarity amongst members. Other denominations with significant German-Russian membership typically offered religious services in English to retain the youth, but many German-Russians - particularly those of pietistic minority sects including the evangelical Brethren—objected to the turn away from their traditional dialect. In addition to the use of the traditional language German Congregational Churches featured fellowship-style worship, and the high social status of the preachers evoked memories of religious social structure in the Russian colonies. ${ }^{107}$

The introduction of the German Congregational Church to the Albina settlement heralded the reorganization of Volga German life around the church. The First German Congregational Ebenezer Church, established in 1892 at Northeast Seventh Avenue and Northeast Stanton Street, opened in December with approximately two-dozen members under the leadership of the Reverend Johannes Koch, a prominent Brethren member and schoolteacher from the colony of Kolb in Russia. By February 1893 church membership swelled to over one hundred people. In a letter dated February 6, 1893 Reverend Koch writes, "We have not had a single evening without a meeting since Christmas." 108 As the earliest German Congregationalist Church in the Portland area, records from the Ebenezer Church paint a vivid picture of Volga German transnational connections. The 1895 Ebenezer Church Registry lists the names of congregation members along with their location prior to settlement in Albina and their home colony in

Assisting -Chicago Man Gives Address in Evening," Oshkosh Northwestern, 3 March 1913, https://www.newspapers.com.

${ }^{107}$ Sallet, Russian-German Settlements in the United States, 90-92.

${ }^{108}$ Schreiber, "First German Congregational Ebenezer Church." 
Russia. The registry does not include background information for every name, but a comparison with genealogical records reveals that each traceable name in the registry comes from Norka except in one instance when a single church member is traced to the colony of Balzer. $^{109}$

Although the Ebenezer Church registry is not a complete index of Volga Germans who lived in Albina at the time, it is nevertheless representative of the population as the vast majority of local Volga Germans definitively trace their backgrounds to the colony of Norka. ${ }^{110}$ Klooster reports that in Albina "dozens of former neighbors once again lived and worked side by side" and it seemed as if Norka "had picked itself up and moved halfway around the world." "111 Norka colonists initially settled in the Midwest where they connected with German-Russian communities prior to migration to Albina, but as the Albina settlement firmly established itself the immigrants began to travel from Norka directly to the Portland area. An estimated five hundred Volga German families comprised the Albina segment by the 1930s; most belonged to Norka families that arrived in Portland between 1890 and 1905. ${ }^{112}$

The Ebenezer Church brought neighbors from Norka together again, but it lost many of its members in 1900 with the establishment of the Free Evangelical Brethren Church on December 3, 1900 at 763 Northeast Mallory Avenue. The Brethren Church

${ }^{109}$ See Appendix B, p. 88-92, for Table 1: Tracing Volga German Names in the Ebenezer Congregational Church Registry, Portland, Oregon, 1895.

${ }^{110}$ Many Norka colonists originally immigrated to Russia from Isenburg in the German kingdom. As a result, a large number Portland Volga Germans trace their lineage back hundreds of years to a place of common origin in the Holy Roman Empire.

${ }^{111}$ Klooster, "Notes and Anecdotes," 1.

112 "Portland, Multnomah Co., Oregon," Center for Volga German Studies, http://cvgs.cuportland.edu/immigration/united_states/oregon/portland.cfm; Klooster, "Notes and Anecdotes," 1. 
emerged when the Elder Brother Peter Yost broke away from the Ebenezer Church along with other members to create their own congregation. Membership grew from twenty-six original members in 1900 to ninety-six in 1907, at which point the congregation moved to a new structure at 3605 Northeast Mallory Avenue. With well over one hundred members in 1922, the congregation reorganized as the German Congregational Evangelical Brethren Church. Brother Yost, originally a Norka colonist, oversaw membership at the Brethren Church until 1927. ${ }^{113}$

In 1927 the Saint Nicholas Russian Orthodox Church bought the original 1900 structure that housed the Brethren Church and the German-Russian congregation relocated to a larger building at Northeast Garfield Avenue and Northeast Mason Street. The structure completed its transformation from Volga German to Russian with the addition of a Russian onion dome that still sits atop the structure today—-the work of a Volga German craftsman from Norka named Conrad Weber who lived next door to the church. The Russian Orthodox Church relocated in 1980 and today the structure stands as the Greater Saint Stephen Missionary Baptist Church. ${ }^{114}$ The disappearance of both the Volga German and Russian incarnations of the structure reflects the political climate of the twentieth century that compelled immigrants to shed markers of their identity under the conditions of World Wars I and II.

${ }^{113}$ Schreiber, "First German Congregational Ebenezer Church."

${ }^{114}$ Steve Schreiber, "Free Evangelical Brethren Church," The Volga Germans in Portland, last modified August 4, 2017, http://www.volgagermansportland.info/freeevangelical-brethren-church.html; Steve Schreiber, "How the Onion Dome Came to Be: A Volga German-Russian Partnership," The Volga Germans in Portland, last modified November 12, 2016. http://www.volgagermansportland.info/how-the-onion-dome-cameto-be-ndash-a-volga-german-and-russian-partnership.html. 
The anti-German climate that followed World War I and intensified during World War II pressured the Volga Germans to rapidly assimilate as church membership and widespread use of the traditional dialect diminished. A 2006 obituary for Marie Krieger in the Oregonian features an overview of Volga German history and notes that members of the community "deliberated concealed" their German-Russian heritage during the war years, a situation that grew increasingly complicated as communications halted between settlers in the U.S. and their extended families in Russia. ${ }^{115}$ Many of the Volga Germans who remained in Russia suffered grave consequences during World War I as an estimated one hundred and ninety thousand to two hundred thousand German colonists endured deportation to Siberia between 1915 and 1916. Up to one-half of the deported population did not survive. From 1920 to 1921 a severe drought struck the Volga and Caucasus regions and led to the great famine of 1921 to 1923 as harvests yielded only thirty-seven percent of typical production. Known as the Povolzhye, the famine intensified under a Bolshevik policy that required confiscation of grain and ultimately resulted in the deaths of approximately five million people. ${ }^{116}$

In 1921 the New York City-based Russian Commission of the Near East Relief Organization assembled a committee to evaluate the conditions of famine in Russia. The organization published the findings in An American Report on the Russian Famine the same year. The publication details "acute famine conditions" in "every Volga city" where "little or no food is displayed for sale in the markets," with "prohibitive" prices for the

115 "The Greater Portland Community of Germans from Russia Honors Marie (Trupp) Krieger, 1910-2006: Historian, Luminary, and Soul Mate of the Greater Pacific Northwest Community of Germans from Russia," Oregonian, 26 November 2006, 1. ${ }^{116}$ Steve Schreiber, "World War I," The Volga Germans in Portland, last modified November 5, 2017, http://www.volgagermansportland.info/world-war-i.html. 
scant quantity of bread available. Families reportedly ate their horses and consumed bark stripped from succulent bushes. The report concludes that the commissioners remained "profoundly convinced" that the "very serious" situation in Russia warranted the "consideration of the rest of the world.","117

Despite pressure in the U.S. to deemphasize both the German and Russian aspects of their multinational identity, the Volga Germans responded in earnest to the Russian famine when they heard of it through Die Welt-Post, a German-Russian newspaper based in Nebraska that operated from 1916 to 1970 . Beginning in 1921, letters published from community members' family and friends in Russia revealed dire conditions. ${ }^{118}$ In a letter dated April 25, 1921 and traced to the colony of Dönhof in Saratov, an unknown writer laments the situation in Russia:

Your father is also sick from hunger. Our wish is that you would come and get us... If you believe that one can still live in America, then do thus; because all hope of the people surviving here is lost; if no help comes very soon from Katharinenstadt then many will not live to see the new harvest. ${ }^{119}$

Upon hearing news of the crisis in Russia, Portland Volga Germans John W. Miller and George Repp — both of Norka families_-resolved to form a community aid society. Miller sent a letter to the American Relief Administration to ask for support on behalf of "approximately fifteen hundred people in Portland that came from German colonies

\footnotetext{
${ }^{117}$ Near East Relief Organization, An American Report on the Russian Famine: Findings of the Russian Commission of the Near East Relief (New York: The Nation, 1921), 8-9. 118 "Die Welt-Post," Center for Volga German Studies, last modified February 21, 2009, http://cvgs.cu-portland.edu/literature/Periodicals/welt_post.cfm.

119 “A Letter From Russia,” Die Welt-Post, 14 July 1921, 5, available at http://cvgs.cuportland.edu/literature/Periodicals/welt_post/19210714.cfm.
} 
located in Russia" and expressed a wish to "help get food into that stricken district.","20 The organization agreed to provide aid for the purpose of feeding children in Russia, and with this affirmation Miller and Repp organized a meeting at Zion Congregational Church in Albina on August 11, 1921. In the presence of approximately one hundred community members Miller and Repp established the Volga Relief Society. Within days the group sent letters to German Congregational churches across North America to engage other Volga German communities in a national aid campaign. Lutheran and Evangelical churches with large Volga German congregations heard the news and joined the effort. Within days the Volga Relief Society partnered with the American Relief Society to send Repp to Russia as a delegate to oversee the delivery of supplies to the Volga region. ${ }^{121}$

Portland Volga Germans traveled to German-Russian communities around the U.S. to organize regional branches of the Volga Relief Society while Repp supervised the aid effort in Russia. Forty thousand children in the Volga region received consistent feedings from the relief organization by February of $1922 .{ }^{122}$ In a letter dated the same year, a representative traveling in Russia with the American Committee for Relief of Russian Children reports back to the organization that the American Relief Administration provided "according to Russian and American statistics both, ninety-five

\footnotetext{
${ }^{120}$ John W. Miller, quoted in a letter to the American Relief Administration in Scheuerman and Trafzer, The Volga Germans, 200.

${ }^{121}$ Emma Schwabenland Haynes, A History of the Volga Relief Society (Lincoln, Neb.: American Historical Society of Germans from Russia, 1982), 34; Steve Schreiber, "The Volga Relief Society," The Volga Germans in Portland, last modified February 15, 2018, http://www.volgagermansportland.info/the-volga-relief-society.html.

${ }^{122}$ Scheuerman and Trafzer, The Volga Germans, 202.
} 
percent" of the relief in Russia that served "ten million people." ${ }^{, 23}$ In total the Volga Relief Society raised an estimated five hundred and fifty thousand dollars worth of food and provisions to help inhabitants of the Volga region between 1921 and $1922 .{ }^{124}$ The Volga Relief Society remains a symbol of the communal spirit that characterizes the Volga Germans and connects them globally. Even as social tension surrounded their identity in the U.S. under the conditions of World Wars I and II, the Volga Germans of Albina nevertheless engaged the German-Russian network to aid their transnational community.

Despite the solidarity that propelled aid efforts in the 1920s, the Volga Germans of Albina dispersed and assimilated through the next decades of the twentieth century. As Marie Krieger writes in her 1987 article, the Volga Germans dispersed in the shuffle of an "Albina exodus" as new populations arrived to work in the nearby shipyards.

Neighborhood cohesion declined along with church membership as Volga Germans sought "English speaking churches or none at all." Yet some Portland Volga Germans still "clung tenaciously to their mother tongue" through prayer group meetings until the 1980s "when most of the veteran members had been laid to rest." As Krieger reflects, “Aller Anfang hat eine Ende,” or every beginning has an end. ${ }^{125}$

The unwritten history of the Portland Volga Germans is ultimately attributable to circumstances that diminished the visibility of the Albina community in comparison to more isolated German-Russian settlements. The traditional Volga German way of life

${ }^{123}$ Geo. Stuart, Jr. to Capt. Paxton Hibben, October 10, 1922, in An American Report on the Russian Famine: Findings of the Russian Commission of the Near East Relief (New York: The Nation, 1921), 23.

${ }^{124}$ Scheuerman and Trafzer, The Volga Germans, 199-203.

${ }^{125}$ Krieger, "The Portland Community of Russian Germans," 35-36. 
centers on communal agriculture, but the immigrants who settled in Albina at the beckoning of transportation and development companies quickly took up industrial jobs and other wage work. In contrast, German-Russians who settled in rural eastern Washington remained identifiable for longer due to greater geographic isolation and retention of the farming lifestyle. Although Albina Volga Germans are recognizable in census lists of the late nineteenth and early twentieth centuries due to documentation of their Russian nationality and German language, U.S.-born descendants are not identifiable according to immigration or language classifications. The Little Russia designation often pinned on German-Russian neighborhoods by those external to the community highlights the way in which a lack of understanding about the Volga Germans' multinational origins erased their public identity and heightened the internal group desire to self-identify. The German Congregational Church once represented a shared space for German-Russian performance of community identity, but the social and political pressure for assimilation resulted in diminished membership in the second half of the twentieth century. Volga German descendants today call on nostalgia to enact renditions of identity that transcend the borders of nations and the boundaries of belonging. 


\section{Chapter IV}

\section{We Are Also Bound Together: Nostalgia for a Shared Past}

This chapter features a small selection of interviews conducted in Portland with several members of the local Volga German community to explore the ways in which oral histories offer valuable information about groups unrecognized in the archival record. Given that the shortage of historical evidence poses a significant challenge to indepth analysis of the Volga German settlement in Portland, these oral histories help to address archival omissions and highlight the complexity of the largely undocumented history of this group in Portland. The interview participants each possess varying perspectives and experiences that do not establish any facts about Volga Germans as a whole group. Rather, these individual accounts display the multi-faceted dimensions of identity. ${ }^{126}$

For many Volga Germans the motivation to emigrate out of Russia stemmed from conditions of political unrest and the loss of freedoms in the late nineteenth and early twentieth centuries. Marilyn Schleining Schultz, born in the Portland Volga German community in 1937, explains the political agitation in early twentieth-century Russia that motivated her grandfather to immigrate to Portland where his sister lived in the neighborhood known as Little Russia.

Let me go back to when my grandfather came to Portland. That was in 1906 . He had been a soldier in the Tsar's army, and of course the early uprisings in Russia

\footnotetext{
${ }^{126}$ Oral history interviews conducted at the Center for Volga German Studies in Portland, Oregon between November 2016 and December 2017. Videos archived by Steve Schreiber in "Stories," The Volga Germans in Portland, last modified March 1, 2018, https://www.volgagermansportland.info/stories.html. An additional interview conducted via email with Steve Schreiber in February 2018 is also featured in this chapter.
} 
were occurring in 1905,1906 . And as a member of the Tsar's army he was targeted by the Bolsheviks as an enemy of the people. So, in the summer of 1906 he and his wife and their young son, who was just a baby, and that was my oldest uncle, decided they would leave. My grandfather's sister had come to Portland with her husband a year or two before and settled in the same neighborhood as many, many other Volga Germans. They were from the village of Norka, and so they came, um, by ship, of course, to Boston - when I was in New York years ago I thought they might have come into Ellis Island and I searched for their records there and there was nothing. But it turns out they came into Boston and then they took the train from Boston across the country. They came directly then to Portland. Um, at that time the German neighborhood was called Little Russia, and it was from about Seventh to Fifteenth and from Fremont to Prescott.

Roy Conrad Derring, a Volga German descendant born in 1939 whose father emigrated from Russia to Northeast Portland in 1912, refers to a family photo as he describes the difficult conditions endured by his father's remaining family members in Russia.

They were very poor as well. I mean, you can tell, and the thing is my grandfather wasn't in this picture because he, prior to this picture, um, that was taken, he froze to death on a sleigh that was coming back in the winter time from another village. He was a meat cutter. And so, they lost their father and for a woman to lose her husband is like losing a leg or an arm... [My father's two older brothers] were in the military, from 1914 to 1917 , and the only thing that saved my uncle Adam from the firing squad was because he was a prisoner of war, so, the war was over, and the revolution had already taken place, so when they came back they were indoctrinated and not treated very well. And at that time all the livestock was taken away from the Germans. All the farming equipment was taken away. All the seed grain for planting more crops was taken away. And that was one of the worst parts. That was a systematic thing that I strongly feel was, um, to starve these people to-starve them, which came about where they had the famines of 1921.

Letters remained a powerful symbol of transnational connection as they provided a link between dispersed community members. By the turn of the century the exchange of letters between Albina settlers and their friends and family in Russia stimulated a new 
wave of immigration. Derring observes that letters played a significant role in his family's decision to immigrate to the U.S.

The family was receiving letters from America from [my father's] oldest sister, Louisa, and her husband, uh, Henry Blum, and at that time they were marriedthey had married in Russia and then they came to America. Also, I believe it was around 1904 when they came. And then his oldest brother who was ten years older already had a family in Russia and they immigrated as well. So they had an - they were established here, and then they were receiving letters in Russia from them, and um, my father was just chomping at the bit. He wanted to go to "America, America."

Derring points out that the onset of the Russian Revolution, an event that closely followed the largest wave of Volga German immigration to Albina at the turn of the twentieth century, represents a time of hardship in Volga German memory as the exchange of letters halted and many community members in the U.S. lost contact with their friends and family in Russia.

These were very hard, bad times, and not only that but when my father was here and his sister and her family and my uncle and his family, there was no longer communication with Russia. You couldn't send letters back and forth. I think itI can't remember when exactly that stopped but during the revolution it certainly interrupted all communication. So, my father didn't know what happened to his mother, he didn't know what happened to his brother Peter, his sister Anna, and what happened to the two brothers. And it was learned later that, uh, the brother Johannes faced the firing squad - returning veteran. Um, and, there was a story that my father told me he had heard that he had a chance to get away, but he didn't want to desert his friends, his comrades that he was in the military with.

The exchange of letters resumed later in the twentieth century, but new difficulties arose as community members in the U.S. could no longer locate their friends and relatives in Russia. Under the leadership of Joseph Stalin the United Soviet Socialist Republic initiated a policy of mass deportation in 1941 to relocate ethnic minorities including Volga Germans, along with other social groups deemed unfit for Soviet life, into 
controlled settlements of exile located primarily in Siberia and Central Asia. ${ }^{127}$ Derring recounts how the local Volga German network helped his father to locate his deported sister in Russia after communication resumed.

We're talking about over fifty years had passed with no communication. Not knowing what exactly happened. Knowing there were deaths but not the circumstances. My father, through someone who had a barber shop not far from here up on Ainsworth and Thirtieth, um, the building's still there, I think it's a little restaurant or something like that, I'm not sure exactly, but this barber who was of German from Russia extraction, uh, was able to help my father, uh, to find out how he could get in touch with his sister in Russia, where in Russia or even that he knew that he could find her. So the barber told my father to-here's a man who owns a locksmith shop on Union Avenue which is now MLK [Martin Luther King Jr. Boulevard ${ }^{128}$ ], um, that, to go see this man and he can help you. So my father went there... And so my father did get my aunt's address... They were inmy aunt was in Siberia. My aunt Anna Katrina. So they maintained this back and forth. And I remember being with my father at the post office downtown where he was sending a letter off, and then he got a letter back, he got several letters back, and he got a letter back that - "don't send money," because he was sending maybe ten or twenty dollar bills or whatever, because it would be confiscated.

In addition to letters, language served as another transnational symbol that united community members. While the Volga Germans' old regional form of German with adopted Russian words and phrases helped to clearly identify them in Russia, in the latenineteenth and early twentieth centuries identification of the Volga Germans in the U.S. derived from the combination of German language and Russian nationality. In the early years of the Portland Volga German settlement the use of the traditional dialect remained common, as Schultz explains.

\footnotetext{
${ }^{127}$ Steve Schreiber, "Deportation 1941,” Norka, Russia, https://www.norkarussia.info/deportation-1941.html

${ }^{128}$ The city of Portland changed the name of Union Avenue to Martin Luther King Jr. Boulevard in 1989.
} 
In the old German neighborhood everybody still spoke German, and they cooked German foods, and it was, it was a very different atmosphere. On the street where I grew up people were of every nationality and, you know, it was a much bigger mix... I looked at the, um, 1920s census for Thirteenth [Avenue]. And you go down the list and it says, um, country of origin-Russia, Russia, Russia, Russia, all the way down the line. And then it said, um, I think it says native tongue or language-German, German, German, German. You know, it was amazing. And most of those people, I believe, were also from Norka, so they were the same village and they just all kind of moved over and, and were very comfortable in that setting. Um, my grandfather never learned English-I mean he knew a few words, but he really could not carry on a conversation in English... Speaking to my grandfather, um, my father and my uncles always spoke in German. Um, old man Danewolf had the grocery store up on the corner, and if I remember right he spoke only German. If I went in there to get something I had to point to it. I don't think he spoke English. Um, all of the adults - I think that's fair-all of the adults there on Thirteenth spoke German. Um, my dad did not learn English until he went to grade school, and, and he went to Sabin [Elementary School], and I believe he was seven years old.

Harold Kammerzell, a Volga German descendant born in Portland in 1934, corroborates

the prevalence of the traditional dialect among Albina residents in the early years.

The people in the area all retained the language, the German language. And so, for us young guys, we had to communicate with the elders in the native language. And it was spoken - at our home it was spoken quite a bit around the table. Uh, in fact when I was in kindergarten, the teacher said you must speak more English, 'cause she could-I was mixing the English and the German together. And she said no, you have to speak English. But I delivered groceries in this area, and so working with the older women in the neighborhood, you know, they all spoke German to me and I had to communicate back.

Harold Kammerzell's wife Loretta, who was born in Portland in 1936, recalls that her

family used the traditional dialect only in certain circumstances.

In my home they spoke mostly English, but when they didn't want us kids to know what they were talking about, they spoke in German. But I could understand everything they were saying. I just didn't speak it quite as well or as often, but I could sure tell what they were saying. 
Steve Schreiber, a Volga German descendant born in Portland in 1956 who participated in an interview via email, remembers the use of the traditional dialect among the older generations and at church services.

Discussion about life in the "old country" was done in German and we kids couldn't understand enough of the dialect... Parts of our church services were still in German when I was younger, and the older folks conversed in the dialect. Some songs were sung in German.

Derring's experience as the son of immigrants from two different countries affected his relationship to some aspects of Volga German culture including exposure to the traditional language. His mother emigrated from Norway and he encountered his Norwegian heritage more frequently than his Volga German heritage as a child. Although Derring's family did not speak German at home, he encountered the dialect in his father's social circles.

We saw our Norwegian family relatives, aunts and uncles, and uh, and I would hear my mother speak in Norwegian with my grandfather. And so, and he would come and visit quite often. But I guess I felt like I identified with that because I was able to interact with it. But I didn't have it with my German side. I had it with my father because my father told me stories and the stories were like in here [refers to photos] of his growing up in Russia and then coming to America. Uh, so I didn't really have that -I'd go around with him to visit with other immigrant Germans and I would hear them speak in the language back and forth... It didn't seem to matter so much if they were from Germany or if they were from, uh, the Volga, from Russia. Uh, it was that they connected because of the language. The language, they connected because they spoke German. We had neighbors from Germany and um, so my father always spoke with them and they spoke with him and it was, uh, a real connection for them.

The language barrier between Volga Germans and non-German speaking inhabitants of Portland affected the selection of jobs available to the immigrants, who gave up agricultural work upon their settlement in industrial Albina. Many Portland 
Volga Germans worked in the garbage hauling business. Harold Kammerzell suggests

that the popularity of garbage hauling among community members is attributable to the

fact that it did not require English fluency.

When they came to this country, in the nine-late eighteen hundreds, early nineteen hundreds up to 1910,1920 , these people, you know, they couldn't speak English very well. And although they came to this country and they were craftsmen - there was some, there was a lot of good ability amongst them - but because of the communication part, you know, they had to take - find lesser work. And they actually, um, most of them started the refuse business for the city of Portland. And, uh, one time I looked at the register. We had over six - no, three hundred and sixty-some families that were in the business.

Schultz also attributes her grandfather's work in the garbage hauling business to the challenges posed by the language barrier.

My grandfather never learned English-I mean he knew a few words, but he really could not carry on a conversation in English. Um, when he came, uh-now the 1920 census lists his occupation as scavenger. And he was a garbage man. And so, he, um, he was one of the first members-I don't know if he was a charter member, but he was a very early member-in 1916 of the Garbage Men's Union in Portland. And of course, I think they all were Germans from Russia. So, um, he started collecting garbage with a horse and wagon, and, and that long garage was like a barn for the horse and for the wagon. And then of course he switched over to a truck, and then several trucks, and then he had some commercial routes, and by his standards I think he became very successful... And so my grandfather, he could pick up garbage, you know, without having to learn the language.

Harold Kammerzell notes that in addition to their involvement in the garbage hauling business some Portland Volga Germans joined manufacturing and industrial occupations in order to overcome the language barrier.

Our families all had businesses in the area, mainly refuse hauling, um, but there were several major manufacturers that other German families worked in, such as Doernbecher [Manufacturing], B. P. John [Furniture Corporation], M. \& M. [Woodworking], Nikolai Sash and Door, and so forth. It was a very, uh, tight area, 
and it had its own shops such as butchers, grocery, hardware, dry goods, and we all-everyone patronized those, and we pretty much stayed within the neighborhood... Again, because of their language, language barrier, a lot of them went-I shouldn't say a lot, but a number of them went to work in the railroad, like the Union Pacific and the Northern Pacific. Uh, in the railroad shops, maintenance shops, and down in the Albina district. And uh, of course that was all within walking distance from the neighborhood. So, there was an advantage there. But a lot of them-because they were very good at woodworking, cabinet making, carpentry, uh, real detailed work - woodwork.

Derring recounts his father's employment with other German-speaking immigrants at local businesses like Doernbecher Manufacturing Company, a furniture business established by a German immigrant from Bavaria.

He was at Doernbecher's, yes. Doernbecher was a German... B. P. John's, my father worked at B. P. John's. My father also worked, I remember as a kid, like five years old, going to downtown Portland where he worked right on Fifth near Burnside, and it was called Stadler Fixture Works, and there were other Germans there. So, they spoke German a lot because they were in the, that business together. And I think, um-I discovered later that, um, they all, the Germans from Russia that were here also worked on railroads.

Schultz also notes that many Volga Germans worked for Doernbecher and others opened their own businesses to serve the community.

Doernbecher was an old German man who hired lots of German boys, and, um, and so my father and my uncles, just about everybody, worked for a time at Doernbecher... There were some who were merchants. There were the Repp brothers who had the market on what was then Union Avenue, um, and there was a hardware-furniture-variety store just a couple of doors down from there that was owned by a Volga German-I can't remember, was it Weiner's? Weimer! Yes.

Derring, who occasionally accompanied his father to local German taverns, observes that the taverns offered a place for his father to display symbols of his steady employment. 
These symbols represented a point of pride for his father who remembered his family's

poverty in Russia.

A lot of the culture was in the taverns down there... It was fun going to the taverns with [my father] because it was lively. I got to go play the jukebox, and I- he referred to me as his bodyguard. And my father would be around-here's all the garbage men. Mostly garbage men in the taverns. And they had their little allowance to go have a beer. And my father, who was-he would always dress up when he went down there. He was in his double-breasted suit. He would be fully dressed. He was quite a sharp dresser, and uh, he would have his diamond rings on and his jewelry. And here he'd come in and here are all the garbage men in their garbage men uniforms, and uh, they'd love to see my dad come because they'd say, there's Coonie. Coonie is a nickname for Conrad. Coonie, or they'd say Kuh-nee, in the dialect it sounds different. But um, so he would always buy beers, you know, set them up for everybody because he didn't want to be like the poor boy from Norka. And he came out of a poor existence because no father around anymore, and then the older ones leaving, and so it was pretty grim circumstances facing the whole family, and the fact that he got out and he was able to get good employment and uh, buy the food he wanted... In German he would use the phrase all the time, "Arbeit macht das Leben süss." Work makes life sweet.

Some Volga German immigrants maintained the special occupations they previously practiced in Russia. After her immigration to Albina, Loretta Kammerzell's grandmother continued her work as one of the Braucherei, the white magic healers who provided treatment in the absence of medical doctors in the colonies. ${ }^{129}$

My grandmother was the doctor, midwife, everything, for the German people, and they all seemed to come there. There was another doctor named Dr. Uhle that took a lot of the German people. And um, but Grandma was the one that they came to mostly. And she did like chiropractic-type work. But all of this was because she was a natural healer. God gave her this special gift-she could hardly speak any English, and yet she just had a touch where she could heal. And I honestly saw people that had broken bones that she set and healed. I saw the man across the street had chopped - he was chopping wood, and he accidentally cut off his thumb. Totally cut it off. And he carried it over on a bread wrapper, ran

${ }^{129}$ Steve Schreiber, "Folk Medicine," The Volga Germans in Portland, https://www.volgagermansportland.info/folk-medicine.html 
across the street, and I was there at Grandma's, saw this happen. And I watched her, 'cause I used to sneak up the stairs and peek into that room and watch her. It just amazed me. And she would mold it. Her fingers were just like this, and she set that thumb on there and it totally healed back.

Loretta Kammerzell's grandmother upheld her traditional folk medicine practice, but she also took up new community-oriented pursuits in the U.S. She joined a local Volga

German Ladies Aid organization alongside other immigrant women in the neighborhood.

I can show you a picture of the Ladies Aid, is what I would call it. I don't know what they called it in German, but this is probably when I was young or just before my time, so you know how old [refers to photo]. But this is a group of the women that got together probably once a week for Ladies Aid meeting, and I'm sure they had some projects I'm not sure about. But my grandmother's in this picture.

In addition to their participation in community endeavors many Volga German

women worked in the home. They typically raised children, maintained the household, and prepared food. Schultz describes the ways in which women managed a community schedule and carried out tasks.

The women in the community had a schedule, um, you know, so they'd wash on one day, they'd iron on another day, they'd bake on another day, um, and it seems like Friday must have been baking day because, uh, we would go-my father and I-to my grandparents' house, and the prize was always a big - well, it seemed big to me then - a big round loaf of rye bread that my grandmother had made... I don't know of any of the women there that worked outside the home. Um, they were pretty traditional, um, you know, most of them had children to take care of, and then they had grandchildren to take care of, and, so, um, I think their lives were not easy - and again, during that time period, the Depression and then the war, everybody was canning, everybody was raising vegetables, and all of that of course fell to the women to do. Um, and in none of these houses did we have central heat, so you had to have somebody who chopped the wood for the fires, for the stoves, and, um, and sometimes that fell upon the women. 
Harold Kammerzell remembers that his family traveled north to rural Washington to

procure fresh baking ingredients for the women of the community.

We had a Volga German couple that lived in Ridgefield, Washington, which at that time was a little distance from the neighborhood. And my grandparents on my mother's side would go out there once a week to get fresh cream, eggs, butter, milk, uh, to bring back to the neighborhood women for their baking. They usually did this on a Friday morning, uh, and I got to ride with them a couple of times to go over there and come back. And then my brother and I had the job of delivering that throughout the neighborhood.

As Loretta Kammerzell relays, many Volga German women prepared traditional foods

from their culture including special meats, cheeses, and breads.

Oh, we had so many wonderful things. Most families had German sausage. There usually were several kinds, and uh, I just remember a meat-type thing that was like a headcheese, it was called Stugen. And it was an ungodly grey color. It wasn't very appetizing looking. But we all seemed to like it... First of all we had German rye bread. And it was a light rye that they used, not a dark rye. And, um, that was a weekly thing. Probably some women baked more than once a week. And then they made what we called Riewwelkuchen, that's one name, and it was nothing but a bread, just a white bread, with these crumb-um, what would we call that? A butter, sugary crumb topping. And then we also had, they'd use the white bread dough, and you would roll it out, very thin, cut it into squares approximately this big, and you'd fill it with usually hamburger that you'd browned and cabbage that you steamed down, and that was your filling. And then you'd bring the points up, pinch them down, flip them over on a sheet, and bake them. And so that was our either Friday night or Saturday night dinner every week for a lot of people... Oh, Grebbel. Grebbel would be like a doughnut, a deep-fried doughnut, but they would cut them in a rectangle with two slits and you -it was a knack to learn how to twist those, drop them into the hot oil, and fry them. And that was one of our big desserts.

Among the traditional dishes, Harold Kammerzell remembers a unique soup familiar to neighborhood children.

We had an unusual soup called Schnitzsuppe. It was a dried fruit soup, you know... What was so funny is about half of the kids in the neighborhood, you 
know, if they knew they were having Schnitzsuppe they'd run home. The other half, find out they're having Schnitzsuppe, and run away! They didn't like it.

Loretta Kammerzell also recalls the soup made from dried fruit boiled in sweetened cream.

You first boil that, and then after the fruit has softened then you add sweetening Mom always used molasses, a little bit of molasses and cream - and you eat it hot. The Scandinavians eat it cold. But, um, the Germans always had it warm or hot... Our family always had the Grebbel with the Schnitzsuppe. A double treat.

Derring notes that bread carried special importance for his family as a staple during impoverished times in Russia.

[My father] would always shop in the markets and come back home with sacks full of, you know, meat and bread and it was like a sin if you didn't have it - if you didn't have bread when you were having dinner that was a sin. You know, you had to have bread because bread was - took him back to here [refers to photo of his family in Russia] and bread was always the filler. If you were hungry you had to have bread. So, there was more than just eating bread-it was, it was the staff of life.

In addition to eating their traditional foods some Volga Germans also retained

religious traditions. Harold Kammerzell, a member of the Second German

Congregational Church, recalls the importance of the church in the local community.

The church was the center of the community, so I was raised in the German Congregational Church... We had, uh, we always said grace at every meal. We had prayer before bed. But everyone in the neighborhood pretty much did that. There were very few families that I can recall that didn't, you know, but as I said earlier the church was the center. And in the neighborhood, there were about four, five churches. Uh, what I do remember, it might seem a little funny, was before the war-you must remember I'm kind of a young guy - but there was a policeman named Barney that patrolled the German ethnic neighborhood, and uh, if any of the young boys got into trouble, he didn't haul them in or anything like that. 'Cause he knew the elders of the various churches, so he just went to the elders and said that guy, you need to reckon with. 
Loretta Kammerzell, who also grew up as a member of the German Congregational

Church, agrees with Harold that the church comprised the center of community life in Albina.

I find that my family, also, their life revolved around the church. That was our faith, but it also was our social life. It seemed like this is mostly what we did.

Schreiber notes that although many Portland Volga Germans joined the German

Congregational Church, some remained with the Lutheran, Reformed, Brethren, or

Catholic denominations to which they previously belonged in Russia.

I think the majority of [my parents' and grandparents'] social group was family and friends from our church who were also Volga Germans. The church was in many ways the social center of the community as well as the spiritual. We attended the Second German Congregational Church [later the Evangelical Congregational Church]. My father's family was part of this congregation. My mother's family belonged to the St. Paul's Evangelical and Reformed Church, but I only visited there on rare occasion or perhaps for a funeral.

Schultz observes that some Volga German immigrants upheld strong religious customs,

but others engaged religion less after settling in the U.S.

This grandmother was very religious [refers to photo]. She went to church several times a week, and it was Ebenezer Congregational Church, um, that's the one that I remember best, and that's the one that had the funeral services, um, for both my grandparents... You know, going back to Russia, um, I think that was, that was one thing that was very, very important to the villages and to the communities there. Um, when they came here, they still had their churches, and-but I think probably many of them were less religious than they had been in Russia.

The diminished emphasis on religion and the traditional dialect with the social and political pressures of World War II meant that many Portland Volga German descendants 
rapidly assimilated in the second half of the twentieth century. Schreiber recounts the process by which younger generations of Portland Volga Germans took up American identities.

My understanding is the community here in Portland assimilated more quickly than in rural areas where the old culture lasted a bit longer. After the Second World War, the assimilation process was well under way. The younger generations were marrying outside the ethnic group and no longer spoke the old dialect. This caused some tension with the older generation who wanted to keep things the same. I suppose it is a process that most ethnic groups go through as they adapt to life in America. I don't know of anyone in my family who wished that our ancestors had stayed in Russia.

Derring observes that he and many of his Volga German peers did not understand themselves according to any ethnic identity in their youth. Rather, they identified foremost as Americans.

At Jefferson [High School] all these kids with German last names, and yet none of us - none, I was never approached, I never approached anyone - it wasn't even in the consciousness of their last names being German. No one came up to me and said oh, are you of German extraction? Volga German extraction, or descent? And uh, I would never have thought of approaching them that way. What we were, what we really were, and I really strongly feel this, we were all American kids, doing all American cultural things.

Much like Derring, Schreiber also did not conceive of himself as an ethnic Volga German in his youth. As part of the assimilated post-World War II generation, his family origins remained unclear to him for many years.

I had no idea that I was part of a Volga German ethnic group until I was in my late 20 s or early 30s. I never heard the term "Volga German" when I was growing up. I did hear people use the term "Our People" but I wasn't really sure what that meant at the time... The part about living in Russia was a mystery until I was older. I used to ask my parents where our family lived in Germany and they told me their parents were from Russia. I thought they were confused and meant "Prussia!" Why in the world would Germans be living in Russia? 
The establishment of German-Russian ethnic organizations including the American Historical Society of Germans from Russia (AHSGR) in northern Colorado in 1968 and the Germans from Russia Heritage Society (GRHS) in North Dakota in 1971 ushered in an era of heritage revival among German-Russian descendants in the U.S. As the older generations that grew up with the traditional language and customs passed away near the end of the twentieth century, some among the younger generations undertook projects to document the culture. Derring remembers the first time he conceived of his father's heritage as ethnic in the 1980s at which point he grew active in Volga German heritage work.

I didn't know an awful lot about, uh, where my father came from, or for that matter where my mother came from... I didn't really get interested until I found out while I was watching TV - since then my father had passed away about eight years ago in 1981 and this was 1988 in the summer, and on television there was a, I think it was called neighbor fair, or neighbor food fair, neighbor fair, and it was, um, down at the waterfront. And there were all these ethnic groups that had booths. And they were also having performances by different places and crafts and things. And I was, just happened to have the television on and watching that, and it came up to the Volga German booth - what? And I just, that's what sparked me. And I was so curious. A Volga German booth, you know, I had never heard of anything like that. Uh, something that got my interest, and my father's Volga German, and so I looked in the phone book and I found the, uh, the church, the one on Fremont, and Seventh? Or not Seventh... Ninth, yeah. And I called the church up, and they referred me to, I think it was Cliff Haberman and Heimbuck? John Heimbuck. Those two. And I got ahold of them and that got me to where the meetings were held, and I joined, and I was very enthused and got into it. And uh, started digging up little photographs that I re-photographed and had printed.

Similar to Derring, Schreiber also gained an interest in his family background after his mother's death concurrent to the period of Volga German heritage revival and the availability of Russian records as the U.S.S.R. dissolved. 
It wasn't until my mother died in 1994 that I really developed my interest in family history. My mother had documented what she knew about the family and had joined an organization called the American Historical Society of Germans from Russia. As I began looking through what she had collected, a sort of "secret world" opened up and for the first time I began putting the pieces together about my grandparents and their ancestors. I was fortunate to be tutored by some of the older members of the Oregon Chapter of AHSGR when I first became interested in my family history. People like Marie Trupp Krieger and Bill Burbach added greatly to my knowledge about the Volga Germans and freely shared their photos and information. I was also fortunate that the timing of my research coincided with the opening of the archives in Russia. Information, such as census lists and church records that we thought had been destroyed was discovered and we continue to find more information. It was an exciting time. Many of us can now trace our ancestry back to the places of origin in modern Germany and other parts of Western Europe. I've connected with branches of my family that are living in Russia, Kazakhstan, and Germany. I'm still learning more twenty years later. The fun part of genealogy is finding connections to living people that I wouldn't have otherwise met. I made a trip to Russia in 2006 with a cousin who lived in Norka and was part of Stalin's deportation of the Volga Germans in 1941. He had not been back to his home village since that time. It was a very emotional experience and one that I will never forget. The famines and deportation were never discussed in my family when I was growing up.

Schreiber met significant obstacles during his research as Volga Germans do not fit into a clear archival category like many other immigrants.

When I first started researching my family, I found virtually nothing on this topic at the established history organizations in Portland. Over many years, I've worked on piecing the story of the Volga Germans in Portland together.

Despite the archival difficulties that continue to pose a challenge to researchers, Schreiber nevertheless carried out many in-depth research projects about Volga German history and culture. He created the websites The Volga Germans in Portland and Norka, Russia, served on the board of the Oregon Chapter of the AHSGR, and helped establish Concordia University's Center for Volga German Studies [CVGS], a large collection of 
heritage materials that serves as a hub for local community members who wish to research their family histories.

I think it started as an intriguing family mystery. At first, I was focused on genealogy and started to piece together how I was related to so many people. My father was one of four children and my mother was one of thirteen children. It seemed like I was related to everyone when I was growing up. It all started to come into focus as I documented the family connections. Later, I became interested in the history, culture, traditions and music of the Volga Germans. I've done a good deal of reading on the topic and have two websites that I maintain. I served on the AHSGR Oregon Chapter board for about twenty years and also helped found the Center for Volga German Studies at Concordia University. I guess you could say that I'm in fairly deep at this point. It's important to me because I've learned so much about my family and about myself. Many of my childhood mysteries were solved and now make sense to me. I learned not to judge my parents, but to accept that they were also shaped by their parents, grandparents, et cetera. Our history does shape the present and future. I've also learned through DNA analysis how people around the world are connected, not just Volga Germans, but all of us. Even though my ancestry is one hundred percent Volga German, I can now see the evidence of how I am related to people all over the world, many of which have no Volga German ancestry. We all have our own important stories to tell, but we are also bound together in a much larger story of human development and migration.

These interviews demonstrate that the oral history method brings to the fore variations in community members' individual experiences and perceptions of shared identity to provide greater depth to historical analysis as compared to the use of text documents alone. Although these oral histories convey only the personal experiences and perspectives of a few individuals, this information nonetheless helps us to understand the function of identity in the process of migration and settlement. The community members featured here indicate that they came to an understanding about the importance of their heritage both to themselves individually and in regard to their experiences of a shared past. They reflect on the ways in which letters, language, church membership, social 
networks, and professions tied them to a shared identity in spite of migrations across great distances. However, subsequent generations of descendants experienced greater difficulty in the maintenance of those same ties due to estrangement from family and friends in Russia after the revolution and as traditional cultural practices gave way to the pressures of assimilation in the burgeoning city of Portland.

This thesis highlights the scope of the complexity unearthed when migration and colonization are considered in a global perspective. The Volga Germans' construction of a separate identity mitigated their fluctuating status as both insiders and outsiders of two expanding empires seldom held in comparison. Both Russia and the U.S. deployed internal colonization to secure territory acquired through continental expansion where similar missions to elevate civilization justified the conquest of indigenous peoples and the settlement of immigrants on frontiers considered to be uninhabited. ${ }^{130}$ This analysis of a group's migration and settlement in two comparable empires reveals inconsistencies in legal and social categories of belonging within and across boundaries as the Volga Germans transformed from government-sponsored recruits to refugees without a state.

The Volga Germans' privileged position in the framework of imperial Russia's colonization project initially differentiated them from other ethnic enclaves in eastern Europe including the displaced Poles, but the dissolution of their legal status in the nineteenth century and their objection to the draft of Russian reserve forces drew the Volga Germans into the early twentieth-century wave of migration when many eastern

\footnotetext{
${ }^{130}$ Steven Sabol, "The Touch of Civilization": Comparing American and Russian Internal Colonization (Boulder: University Press of Colorado, 2017), 3-7.
} 
Europeans immigrated to North America. ${ }^{131}$ Their settlement in the U.S. West where global forces converged disproves Turner's argument that settlement of the frontier ceased in 1890. On the contrary, territorial expansion and industrialization fueled the growth of western cities into the twentieth century and the completion of transcontinental railroad links in turn facilitated more migration. These systems influenced the growth of Portland and other western cities as points of connection between entities nationally and internationally. ${ }^{132}$

The Volga Germans who remained in Russia endured deportation to Siberia and Central Asia where they became refugees in the Soviet state. While some deported Volga Germans permanently remained in their locations of exile, many immigrated back to Germany beginning in 1987. Yet the Volga Germans' return to Germany did not constitute a return to the homeland so much as a search for asylum. Many German citizens viewed the post-Soviet Volga Germans as Russians and in the early 1990s the German government sponsored a program to encourage ethnic Germans to remain in the former Soviet Union despite the loss of their original colonies of settlement. ${ }^{133}$ For many Volga Germans in Russia, Central Asia, and Europe, the story of their migration and settlement remains unresolved - yet the impulse to engage a spirit of community

\footnotetext{
${ }^{131}$ Roger Daniels, Coming to America: A History of Immigration and Ethnicity in American Life (New York: HarperPerennial, 1991), 214-215.

${ }^{132}$ Richard White, "Western History," in The New American History: Revised and Expanded Edition, ed. Eric Foner (Philadelphia: Temple University Press, 1997), 4; James Belich, Replenishing the Earth: The Settler Revolution and the Rise of the Angloworld (Oxford: Oxford University Press, 2009), 1-4.

${ }^{133}$ Steve Schreiber, "Loss of the Volga Homeland, Assimilation and Emigration," Norka, Russia, last modified February 3, 2018, https://www.norkarussia.info/cultural-loss-19572006.html; Steven Erlanger, "Germany Pays to Keep Ethnic Germans in Russia," New York Times, 9 May 1993.
} 
ultimately connects group members dispersed internationally as part of the global migration story.

The Volga Germans' self-constructed group identity served historically as a tool with which to forge their own category of belonging in an era of mass global migration. The persistence of Volga German identity among community members today demonstrates its function as a framework to help descendants understand their complex past as settlers of uncertain status in two empires. Thus, even as the forty-two million individuals of German descent in the U.S. comprise the single largest ethnic group in the nation, the Volga Germans nevertheless continue to define themselves as a distinct multinational ethnic community. 


\section{Bibliography}

Primary Sources-Archival Collections:

Ethnology Collection, Mss 1521. Oregon Historical Society Research Library. Portland, OR.

Oregon Population: Foreign Born in Oregon, Germans. Vertical file, Oregon Historical Society Research Library. Portland, OR.

Oregon Population: Foreign Born in Oregon, Russians. Vertical file, Oregon Historical Society Research Library. Portland, OR.

U.S. Bureau of the Census. Census information for 1900, 1910, 1920. All in Record Group 29; National Archives, Washington, D.C. National Archives Microfilm Publication.

\section{Primary Sources-Government Documents:}

Library of Congress. "An Act to secure Homesteads to actual Settlers on the Public Domain." A Century of Lawmaking for a New Nation: U.S. Congressional Documents and Debates, 1774 - 1875. Statutes at Large, 37th Congress, 2nd Session.

Near East Relief Organization. An American Report on the Russian Famine: Findings of the Russian Commission of the Near East Relief. New York: The Nation, 1921.

Oregon State Board of Immigration. Oregon: Facts regarding its climate, soil, mineral and agricultural resources, means of communication, commerce and industry, laws, etc., etc., for general information. Boston: Oregon State Board of Immigration, 1877.

Rusling, James F. The Great West and Pacific Coast; or, fifteen thousand miles by stagecoach, ambulance, horse-back, railroad, and steamer-across the continent and along the Pacific Slope-through the Rocky Mountains, down the Columbia River, over the Sierra Nevadas-among Indians, Mormons, miners and Mexicans. Report compiled for the U.S. Government. New York: Sheldon \& Company, 1877. 


$$
\text { Primary Sources-Books: }
$$

Fadlān, Ahmad Ibn. Mission to the Volga. Translated by James Montgomery. New York City: NYU Press, 2017.

Polk's Portland City Directory Vol. 1939, LXXIV. Portland: R. L. Polk \& Co., 1939. Reeder, Roberta, editor and translator. Russian Folk Lyrics, Bloomington: Indiana University Press, 1993.

Sinner, Peter. Germans in the Land of the Volga. Translated by Dona Reeves-Marquardt. Lincoln, Neb: American Historical Society of Germans from Russia, 1989.

Turner, Frederick Jackson. The Frontier in American History. New York: Henry Holt \& Company, 1920.

Wolga Gesangbuch: der deutschen evangelischen Kolonien an den Wolga. Chicago: Wolga Book Co., 1916.

$$
\text { Primary Sources - Newspapers: }
$$

“A Day’s Town News.” Topeka Daily Capital, 6 November 1915.

“A Letter From Russia.” Die Welt-Post, 14 July 1921, 5.

"Almost Too Late: The Drought Fully Broken: Refreshing Showers." Winchester Argus, 18 August 1887.

“Capitol Notes," Weekly Commonwealth, 5 July 1887.

"Clipped and Condensed: News Items From all Over the Northwest." Morning Astorian, 26 November 1889.

Erlanger, Steven. "Germany Pays to Keep Ethnic Germans in Russia," New York Times, 9 May 1993.

"Fly Is Menace to Public's Health; Swat Him Hard: House Pest Killed More American Soldiers During Spanish War Than Bullets of the Enemy; How to Fight Insect." Oregon Daily Journal, 4 June 1911.

“German-Russian Colony Evidence of City's Growth.” Lincoln Journal Star, 23 October 1914.

"How Drought Benefits the Soil.” Evening News, 3 February 1888. 
"Know Your Portland." Oregon Daily Journal, 2 February 1921.

"Lay a Cornerstone: Building of New Russian German Congregational Church Formally Dedicated Sunday, Professor Meske of Chicago Theological Seminary Assisting -Chicago Man Gives Address in Evening." Oshkosh Northwestern, 3 March 1913.

“Lincoln’s German Russians.” Nebraska State Journal, 3 February 1907.

“Lincoln Gets Drenching.” Omaha Daily Bee, 2 July 1906.

“North Side News.” Topeka State Journal, 9 June 1911.

“Oh! This Busy World.” Morning Oregonian, 9 May 1888.

"The Greater Portland Community of Germans from Russia Honors Marie (Trupp) Krieger, 1910-2006: Historian, Luminary, and Soul Mate of the Greater Pacific Northwest Community of Germans from Russia." Oregonian, 26 November 2006.

"Why Russian Farmers in Kansas Flopped to the Republicans." Spokane Press, 11 September 1905.

“Would Not Suit Viereck.” Buffalo Enquirer, 30 July 1917.

$$
\text { Secondary Sources-Books: }
$$

Belich, James. Replenishing the Earth: The Settler Revolution and the Rise of the Angloworld. Oxford: Oxford University Press, 2009.

Daniels, Roger. Coming to America: A History of Immigration and Ethnicity in American Life. New York: HarperPerennial, 1991.

Dietz, Jacob E. History of the Volga German Colonists. Edited by I. R. Pleve and E. R. Yerina. Moscow: Gotika Press, 1997.

Foner, Eric, editor. The New American History: Revised and Expanded Edition. Philadelphia: Temple University Press, 1997.

Golden, Peter B. Central Asia in World History. New York: Oxford University Press, 2011.

Haynes, Emma Schwabenland. A History of the Volga Relief Society. Lincoln, Neb.: 
American Historical Society of Germans from Russia, 1982.

Haynes, Emma Schwabenland. German Russians on the Volga and in the United States. Lincoln, Neb: American Historical Society of Germans from Russia, 1996.

Originally submitted as the author's MA thesis, University of Colorado, 1927.

Hughes, Lindsey. Russia in the Age of Peter the Great. New Haven: Yale University Press, 1998.

Itzkowitz, Norman. Ottoman Empire and Islamic Tradition. Chicago: University of Chicago Press, 1972.

Koch, Fred C. The Volga Germans: In Russia and the Americas, from 1763 to the Present. University Park, PA: Pennsylvania State University Press, 1977.

Mai, Brent Alan and Dona B. Reeves-Marquardt. German Migration to the Russian Volga (1764-1767): Origins and Destinations. Lincoln, Neb.: American Historical Society of Germans from Russia, 2003.

Markova, Ivana, editor. Trust and Democratic Transition in Post-Communist Europe. New York: Oxford University Press, 2004.

Moskos, Charles C. and John Whiteclay Chambers, editors. The New Conscientious Objection: From Sacred to Secular Resistance. New York: Oxford University Press, 1993.

Pleve, Igor R. The German Colonies on the Volga: The Second Half of the Eighteenth Century. Translated by Richard R. Rye. Lincoln, Neb.: American Historical Society of Germans from Russia, 2001.

Sabol, Steven. "The Touch of Civilization”: Comparing American and Russian Internal Colonization. Boulder: University Press of Colorado, 2017.

Sallet, Richard. Russian-German Settlements in the United States. Fargo: North Dakota Institute for Regional Studies, 1974.

Scheuerman, Richard D., and Clifford E. Trafzer. The Volga Germans: Pioneers of the Northwest. Moscow, Idaho: University of Idaho Press, 1980.

Scheuerman, Richard D. Pilgrims on the Earth: A German Russian Chronicle. Fairfield, WA: Ye Galleon Press, 1974.

Wade, Rex A. and Scott J. Seregny, editors. Politics and Society in Provincial Russia: Saratov, 1590-1917. Columbus: Ohio State University Press, 1989. 
Williams, Hattie Plum. The Czar's Germans: With Particular Reference to the Volga Germans. Edited by Emma S. Haynes, Phillip B. Legler, and Gerda S. Walker. Lincoln, Nebraska: American Historical Society of Germans from Russia, 1975.

Secondary Sources-Articles:

Adas, Michael. "Imperialism and Colonialism in Comparative Perspective." International History Review 20, no. 2 (June 1998).

Roos, Roy. "Albina area (Portland)." Oregon Encyclopedia. Web article. Last modified December 17, 2017. https://oregonencyclopedia.org/

Bade, Klaus J. "From Emigration to Immigration: The German Experience in the Nineteenth and Twentieth Centuries." Central European History 28, 4 (1995).

Brubaker, Rogers. "Migration, Membership, and the Modern Nation-State: Internal and External Dimensions of the Politics of Belonging." Journal of Interdisciplinary History 41, no. 1 (Summer 2010).

Greene, Jack P. "Colonial History and National History: Reflections on a Continuing Problem." William and Mary Quarterly 64, no. 2 (Third Series, April 2007).

Kinbacher, Kurt E. "Life in the Russian Bottoms: Community Building and Identity Transformation among Germans from Russia in Lincoln, Nebraska, 1876 to 1926." Journal of American Ethnic History 26, no. 2 (Winter 2007).

Kloberdanz, Timothy J. "The Volga Germans in Old Russia and in Western North America: Their Changing World View." Anthropological Quarterly 48, no. 4 (1975).

Klooster, Karl. "Round the Roses: Notes and Anecdotes.” This Week Magazine, October $28,1987$.

Kramer, Paul A. "Power and Connection: Imperial Histories of the United States in the World.” American Historical Review 116, no. 5 (December 2011).

Krieger, Marie. "The Portland Community of Russian Germans." Journal of the American Historical Society of Germans from Russia 10, no. 3 (Fall 1987).

McKeown, Adam. "Global Migration, 1846-1940.” Journal of World History 15, no. 2 (June 2004). 
Nickell, Amber N. “Cultivating 'Roots': Towards a Diasporically Imagined Transnational Community, the American Historical Society of Germans from Russia, 1968-1978." Traversea: Journal of Transatlantic History 2 (2012).

Otterstrom, Samuel M. and Carville Earle. "The Settlement of the United States from 1790 to 1990: Divergent Rates of Growth and the End of the Frontier." Journal of Interdisciplinary History 33, no. 1 (Summer 2002).

Pomeroy, Earl. "Toward a Reorientation of Western History: Continuity and Environment," Mississippi Valley Historical Review 41, no. 4 (March 1955).

Sinke, Suzanne M. "Crossing National Borders: Locating the United States in Migration History." OAH Magazine of History 19, no. 3 (May 2005).

Waters, Tony. "Towards a Theory of Ethnic Identity and Migration: The Formation of Ethnic Enclaves by Migrant Germans in Russia and North America." International Migration Review 29, no. 2 (Summer 1995).

Weikum, Mary Koellermeier. "Oregon Germans That Came From Russia.” The Bulletin, March 9, 1977.

Secondary Sources - Websites:

Center for Volga German Studies. Last modified January 10, 2018. http://cvgs.cu-portland.edu/

Germans From Russia Heritage Collection. Last modified February 23, 2018. https://library.ndsu.edu/grhc/

Schreiber, Steve. Norka, Russia. Last modified February 18, 2018. https://www.norkarussia.info/

Schreiber, Steve. The Volga Germans in Portland. Last modified March 2, 2018. https://www.volgagermansportland.info/ 


\section{Appendix A: Maps}

Figure 1. Map of the Volga Region in Russia ${ }^{134}$

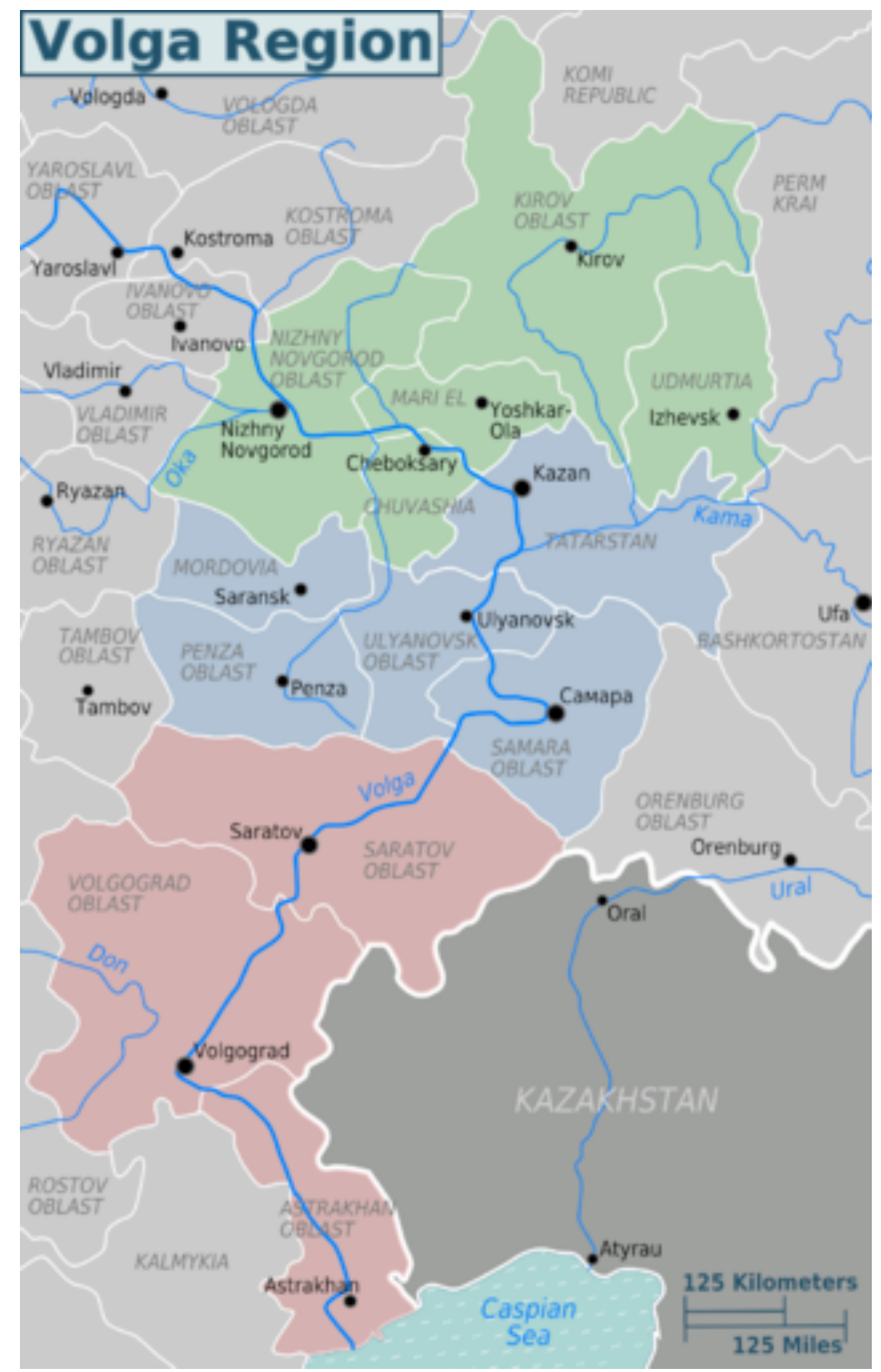

${ }^{134}$ Peter Fitzgerald. "Volga Region.” Wikimedia Commons, accessed February 28, 2018, available through creative commons licensing, https://commons.wikimedia.org/wiki/File:Volga_regions_map2.png. 
Figure 2. Map of the Volga German Colonies ${ }^{135}$
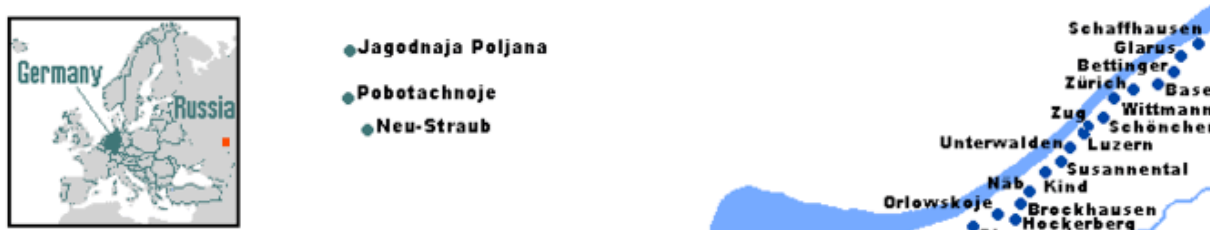

Glarusen

ettinger:

Basel

zug. Wittmann

Unterwaldeno Luzern

Nab. Kind Sannental

Broek

ausen

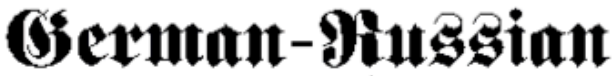 Volyn Hren}

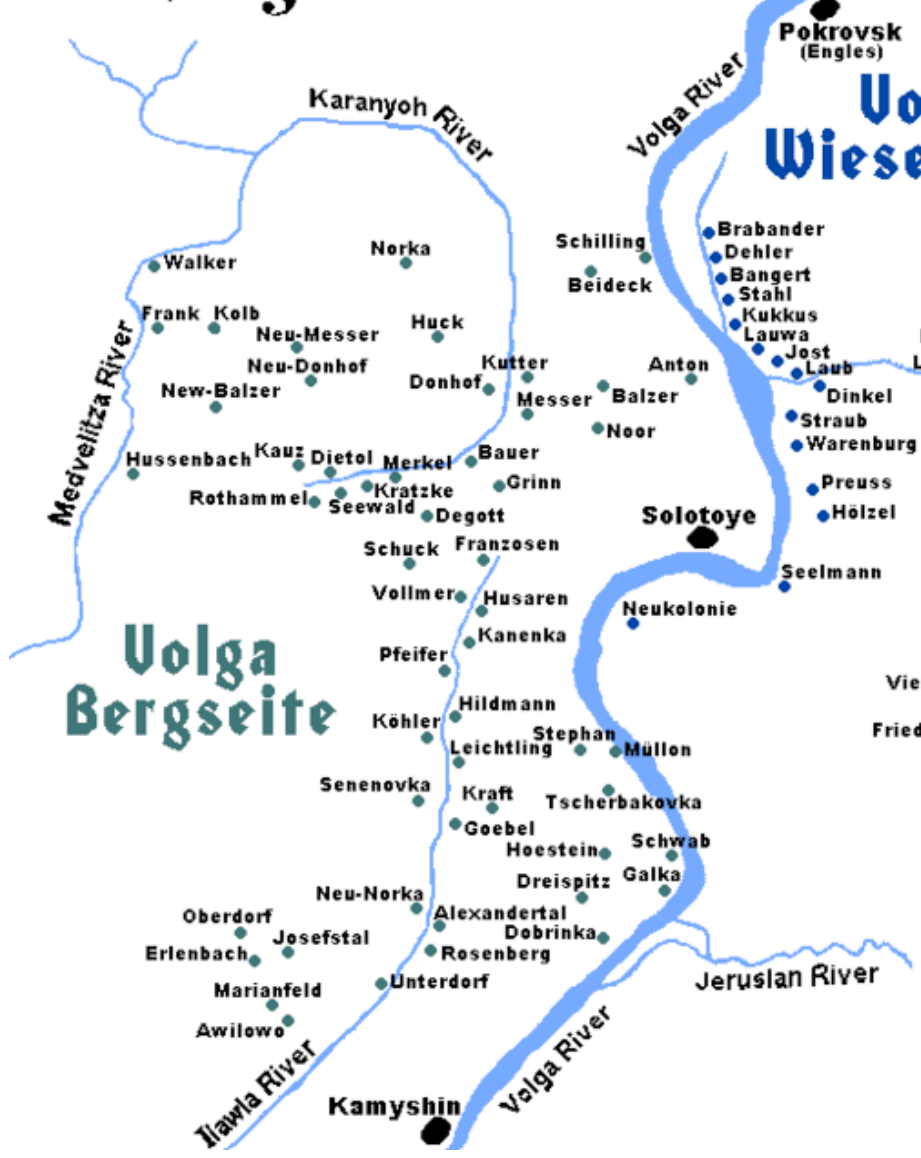
Rosenheim Eaulskoje Enders Philipp Steld Beckerdort

Krasnojaro Schwed Stah $^{\circ}$ Schulz Reinhardto Urbach Schafer Rohleder Grafo Herzog vsk Marientalo 101 Louis, Fresental Neu-Boaro

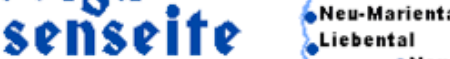
Alexanderhoh Neu-Obernonjou Weizenfeld Gnadendeur -Urbach Wol Rosenfeld $\mathrm{Nan}_{\mathrm{C}} \mathrm{er}$ Neu-Laub

aiv Nedemtal $\because$ Ostenfeld

Fresenheim orloff

Lindenau Hohysanderh

Rosental
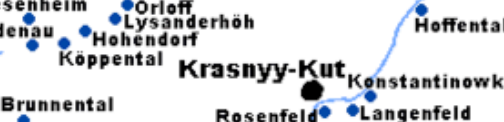

Rosenfeld ${ }^{\circ} \bullet$ Langenfeld

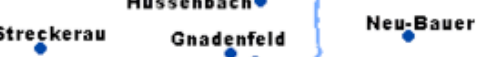

Marięnberg Neu-Beideck Eckheim
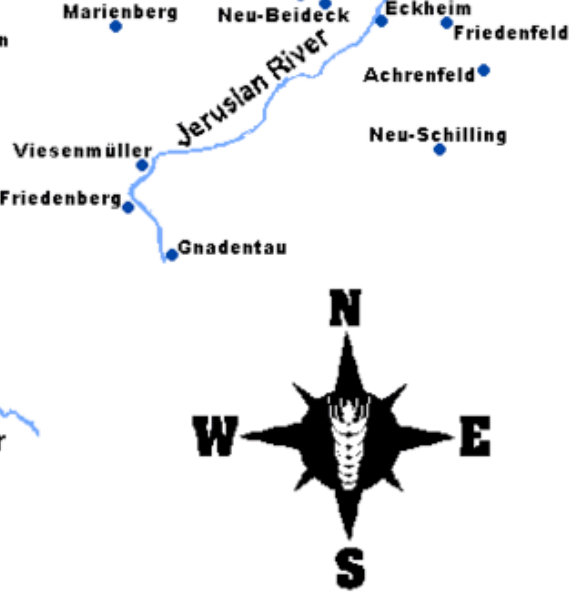

135 "Volga German Colonies in Russia," Wikimedia Commons, accessed February 28, 2018, available through the public domain, https://commons.wikimedia.org/wiki/File:Volga_German_area.gif. 
Figure 3. Map of Portland Neighborhoods ${ }^{136}$

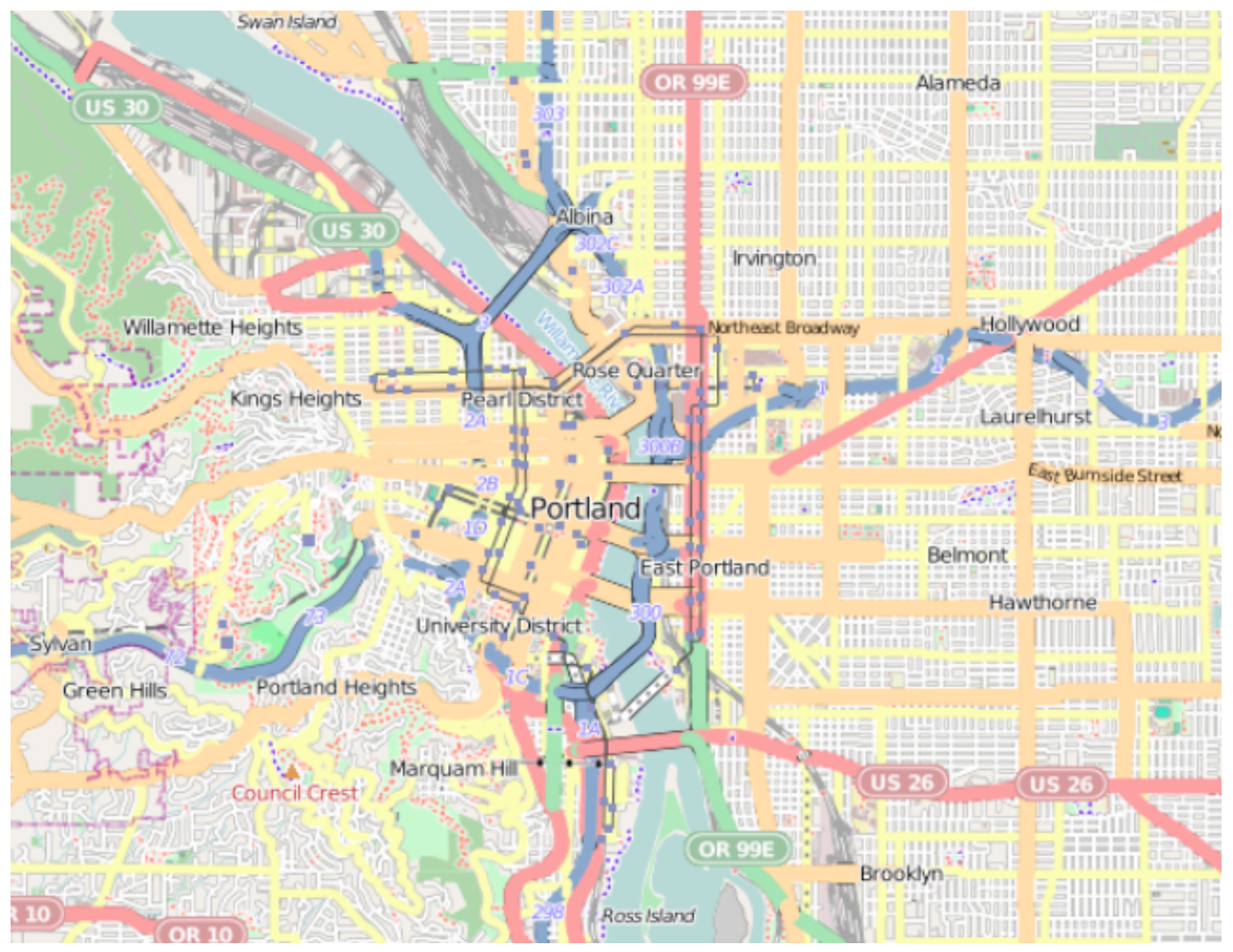

136 "Map of Portland, Oregon, showing neighborhoods and suburbs," Wikimedia Commons, accessed February 28, 2018, available through creative commons licensing, https://commons.wikimedia.org/wiki/File:Portland,_OR,_street_map.png; see Albina located north of Portland on the east side of the Willamette River. 


\section{Appendix B: Tables}

Table 1. Tracing Volga German Names

in the Ebenezer Congregational Church Registry,

Portland, Oregon, $1895^{137}$

This table traces the family backgrounds of individuals who signed their names in the 1895 Ebenezer Congregational Church Registry to demonstrate the strong transnational

link between Volga Germans in Albina, Oregon and Norka, Russia. Some Norka colonists settled in the Midwest before their migration to Albina and others migrated directly from Norka to Albina. The information in this table is derived from crossreferencing the names in the 1895 Registry with U.S. census data, Russian census data, and Volga German genealogy charts.

\begin{tabular}{|c|c|c|c|c|c|}
\hline $\begin{array}{c}\text { Name as } \\
\text { Recorded in } \\
\text { 1895 Registry }\end{array}$ & $\begin{array}{l}\text { U.S. Location } \\
\text { Prior to } \\
\text { Albina }\end{array}$ & $\begin{array}{c}\text { Home } \\
\text { Colony in } \\
\text { Russia }\end{array}$ & $\begin{array}{l}\text { Relative(s) in } \\
\text { Norka Colony } \\
\text { Census, } \mathbf{1 8 5 7}\end{array}$ & $\begin{array}{l}\text { Ancestor(s) in } \\
\text { Norka Colony } \\
\text { Census, } 1767\end{array}$ & $\begin{array}{l}\text { Place of } \\
\text { Origin in } \\
\text { Western } \\
\text { Europe }\end{array}$ \\
\hline $\begin{array}{c}\text { Johannes } \\
\text { Müller (Miller) }\end{array}$ & $\begin{array}{c}\text { Nebraska, } \\
1887\end{array}$ & Norka & -- & $\begin{array}{c}\text { Ernst Wilhelm } \\
\text { Müller }\end{array}$ & $\begin{array}{l}\text { Offenbach, } \\
\text { Isenburg, } \\
\text { Hesse }\end{array}$ \\
\hline $\begin{array}{l}\text { Johannes } \\
\text { Krieger }\end{array}$ & $\begin{array}{c}\text { Sutton, } \\
\text { Nebraska, } \\
1887\end{array}$ & Norka & $\begin{array}{c}\text { Johannes } \\
\text { Krieger }\end{array}$ & $\begin{array}{l}\text { Conrad } \\
\text { Krieger }\end{array}$ & $\begin{array}{c}\text { Queckborn, } \\
\text { Darmstadt, } \\
\text { Hesse }\end{array}$ \\
\hline \multirow{2}{*}{$\begin{array}{l}\text { Adam Jost } \\
\text { (Yost) }\end{array}$} & \multirow[t]{2}{*}{ U.S., 1892} & \multirow[t]{2}{*}{ Norka } & Johannes Yost & \multirow[t]{2}{*}{ Johannes Yost } & \multirow{2}{*}{$\begin{array}{c}\text { Isenburg- } \\
\text { Darmstadt, } \\
\text { Hesse }\end{array}$} \\
\hline & & & Conrad Yost & & \\
\hline \multirow{2}{*}{$\begin{array}{l}\text { Johannes } \\
\text { Bauer }\end{array}$} & \multirow[t]{2}{*}{--} & \multirow[t]{2}{*}{ Norka } & Philipp Bauer & \multirow{2}{*}{$\begin{array}{c}\text { Johann Tomas } \\
\text { Bauer }\end{array}$} & \multirow{2}{*}{$\begin{array}{c}\text { Isenburg- } \\
\text { Darmstadt, } \\
\text { Hesse }\end{array}$} \\
\hline & & & $\begin{array}{c}\text { Heinrich Peter } \\
\text { Bauer }\end{array}$ & & \\
\hline $\begin{array}{c}\text { Heinrich } \\
\text { Aschenbrenner }\end{array}$ & $\begin{array}{c}\text { Sutton, } \\
\text { Nebraska, } \\
1886\end{array}$ & Norka & $\begin{array}{c}\text { Johannes } \\
\text { Aschenbrenner }\end{array}$ & $\begin{array}{c}\text { Johannes } \\
\text { Aschenbrenner }\end{array}$ & $\begin{array}{c}\text { Darmstadt, } \\
\text { Hesse }\end{array}$ \\
\hline
\end{tabular}

${ }^{137}$ Names in parentheses are documented alternate spellings of an individual's name; * indicates instances in which records are awaiting translation (applies to individuals born after the 1857 census); -- indicates no information is available or the field does not apply. Table compiled by the author in cross-reference with the following records: "Ebenezer Family Registry," Ebenezer Congregational Church and Congregation, 1895, trans. Joanne Greene Krieger et al. (Portland: 1999); U.S. Census Bureau, https://www.ancestry.com; family pedigree charts provided by Steve Schreiber from the Norka Database genealogy collection. 


\begin{tabular}{|c|c|c|c|c|c|}
\hline $\begin{array}{c}\text { Johannes } \\
\text { Giebelhaus }\end{array}$ & $\begin{array}{c}\text { Lincoln, } \\
\text { Nebraska, } \\
1890\end{array}$ & Norka & $\begin{array}{c}\text { Conrad } \\
\text { Giebelhaus }\end{array}$ & $\begin{array}{c}\text { Johannes } \\
\text { Giebelhaus }\end{array}$ & $\begin{array}{c}\text { Isenburg- } \\
\text { Darmstadt, } \\
\text { Hesse }\end{array}$ \\
\hline $\begin{array}{c}\text { Konrad Trüber } \\
\text { (Conrad } \\
\text { Truber or } \\
\text { Treber) }\end{array}$ & -- & Norka & $\begin{array}{l}\text { Heinrich } \\
\text { Trüber }\end{array}$ & Martin Truber & $\begin{array}{c}\text { Isenburg- } \\
\text { Darmstadt, } \\
\text { Hesse }\end{array}$ \\
\hline $\begin{array}{c}\text { Johann Georg } \\
\text { Hahn }\end{array}$ & Nebraska & Norka & $*$ & $*$ & $*$ \\
\hline $\begin{array}{l}\text { Heinrich Peter } \\
\text { Scheideman } \\
\text { (Scheidemann) }\end{array}$ & -- & Norka & $\begin{array}{c}\text { Martin } \\
\text { Scheidemann }\end{array}$ & $\begin{array}{c}\text { Johannes } \\
\text { Scheidemann }\end{array}$ & Hesse \\
\hline Heinrich Repp & U.S., 1891 & Norka & Peter Repp & $\begin{array}{c}\text { Johann Conrad } \\
\text { Repp }\end{array}$ & $\begin{array}{c}\text { Isenburg- } \\
\text { Darmstadt, } \\
\text { Hesse }\end{array}$ \\
\hline Peter Repp & $\begin{array}{c}\text { Sutton, } \\
\text { Nebraska, } \\
1886\end{array}$ & Norka & Heinrich Repp & $\begin{array}{c}\text { Johann Conrad } \\
\text { Repp }\end{array}$ & $\begin{array}{c}\text { Isenburg- } \\
\text { Darmstadt, } \\
\text { Hesse }\end{array}$ \\
\hline $\begin{array}{l}\text { Heinrich Peter } \\
\text { Jost (Yost) }\end{array}$ & -- & Norka & Conrad Yost & Georg Yost & $\begin{array}{c}\text { Büdingen, } \\
\text { Isenburg- } \\
\text { Darmstadt, } \\
\text { Hesse }\end{array}$ \\
\hline $\begin{array}{l}\text { Conrad Jost } \\
\text { (Yost) }\end{array}$ & $\begin{array}{c}\text { Lincoln, } \\
\text { Nebraska, } \\
1890\end{array}$ & Norka & -- & Georg Yost & $\begin{array}{c}\text { Büdingen, } \\
\text { Isenburg- } \\
\text { Darmstadt, } \\
\text { Hesse }\end{array}$ \\
\hline $\begin{array}{l}\text { Peter Weigand } \\
\text { (Weigant) }\end{array}$ & -- & Norka & $*$ & $*$ & $*$ \\
\hline $\begin{array}{l}\text { Heinrich } \\
\text { Albert }\end{array}$ & $\begin{array}{c}\text { Sutton, } \\
\text { Nebraska, } \\
1890\end{array}$ & Norka & Adam Albert & Carl Albert & $\begin{array}{c}\text { Isenburg- } \\
\text { Darmstadt, } \\
\text { Hesse }\end{array}$ \\
\hline
\end{tabular}




\begin{tabular}{|c|c|c|c|c|c|}
\hline $\begin{array}{c}\text { Johannes } \\
\text { Spadi (Spady) }\end{array}$ & -- & Norka & Ludwig Spady & $\begin{array}{c}\text { Johann Conrad } \\
\text { Spady }\end{array}$ & $\begin{array}{l}\text { Afterroth, } \\
\text { Austria }\end{array}$ \\
\hline $\begin{array}{l}\text { Heinrich Kniss } \\
\quad \text { (Kneiss) }\end{array}$ & -- & Norka & $\begin{array}{c}\text { Johannes } \\
\text { Kneiss }\end{array}$ & Georg Kneiss & Hesse \\
\hline $\begin{array}{l}\text { Caspar Hinkel } \\
\text { (Hinkle) }\end{array}$ & -- & Norka & $\begin{array}{c}\text { Johannes } \\
\text { Hinkel }\end{array}$ & $\begin{array}{l}\text { Georg Ernst } \\
\text { Hinkel }\end{array}$ & $\begin{array}{c}\text { Büdingen, } \\
\text { Isenburg- } \\
\text { Darmstadt, } \\
\text { Hesse }\end{array}$ \\
\hline Ludwig Sauer & Kansas, 1887 & Norka & $\begin{array}{c}\text { Johannes } \\
\text { Sauer }\end{array}$ & $\begin{array}{l}\text { Johannes } \\
\text { Sauer }\end{array}$ & $\begin{array}{c}\text { Isenburg- } \\
\text { Darmstadt, } \\
\text { Hesse }\end{array}$ \\
\hline $\begin{array}{c}\text { Johannes Leel } \\
\text { (Lehl) }\end{array}$ & -- & Norka & * & * & * \\
\hline Georg Repp & -- & $*$ & $*$ & $*$ & $*$ \\
\hline $\begin{array}{c}\text { Johannes } \\
\text { Goebel (Göbel } \\
\text { or Gabel) }\end{array}$ & U.S., 1890 & Norka & $\begin{array}{c}\text { Heinrich } \\
\text { Göbel }\end{array}$ & $\begin{array}{l}\text { (unknown) } \\
\text { Göbel }\end{array}$ & Hesse \\
\hline $\begin{array}{c}\text { Peter Henkel } \\
\text { (Hinkel) }\end{array}$ & -- & * & * & * & * \\
\hline $\begin{array}{l}\text { Heinrich Yost } \\
\text { (Heinrich Peter } \\
\text { Yost; Peter } \\
\text { Yost) }\end{array}$ & -- & Norka & $\begin{array}{c}\text { Friedrich Yost } \\
\text { Conrad Yost } \\
\text { Heinrich Yost }\end{array}$ & Georg Yost & $\begin{array}{l}\text { Büdingen, } \\
\text { Isenburg- } \\
\text { Darmstadt }\end{array}$ \\
\hline Heinrich Koch & -- & Norka & * & * & * \\
\hline
\end{tabular}




\begin{tabular}{|c|c|c|c|c|c|}
\hline Wilhelm Lindt & -- & $*$ & $*$ & $*$ & $*$ \\
\hline $\begin{array}{l}\text { Jacob Müller } \\
\text { (Miller) }\end{array}$ & -- & Balzer & $*$ & $*$ & $*$ \\
\hline Peter Schmidt & -- & $*$ & $*$ & $*$ & $*$ \\
\hline Peter Schnell & -- & Norka & $\begin{array}{l}\text { Ludwig } \\
\text { Schnell }\end{array}$ & $\begin{array}{l}\text { Johann } \\
\text { Heinrich } \\
\text { Schnell }\end{array}$ & $\begin{array}{c}\text { Isenburg- } \\
\text { Darmstadt, } \\
\text { Hesse }\end{array}$ \\
\hline $\begin{array}{c}\text { Johannes } \\
\text { Schwarz } \\
\text { (Schwartz) }\end{array}$ & -- & Norka & $\begin{array}{c}\text { Jacob } \\
\text { Schwartz }\end{array}$ & $\begin{array}{c}\text { Johannes } \\
\text { Traugot } \\
\text { (Traugold) } \\
\text { Schwartz }\end{array}$ & Saxony \\
\hline $\begin{array}{l}\text { Johannes } \\
\text { Schleicher } \\
\text { (Schleiger, } \\
\text { Schleuger) }\end{array}$ & -- & $*$ & $*$ & $*$ & $*$ \\
\hline $\begin{array}{l}\text { Friedrich } \\
\text { Sänger } \\
\text { (Singer) }\end{array}$ & -- & $*$ & $*$ & $*$ & $*$ \\
\hline Heinrich Wolf & -- & $*$ & $*$ & $*$ & $*$ \\
\hline $\begin{array}{l}\text { Heinrich } \\
\text { Hölzer } \\
\text { (Helzer, } \\
\text { Helser) }\end{array}$ & -- & Norka & Georg Hölzer & $\begin{array}{c}\text { Johann Conrad } \\
\text { Hölzer }\end{array}$ & Hesse \\
\hline $\begin{array}{c}\text { Johannes } \\
\text { Kniss }\end{array}$ & -- & Norka & $*$ & $*$ & $*$ \\
\hline
\end{tabular}




\begin{tabular}{|c|c|c|c|c|c|}
\hline $\begin{array}{c}\text { Heinrich } \\
\text { Wacker } \\
\text { (Walker) }\end{array}$ & -- & Norka & $*$ & $*$ & $*$ \\
& & & & & \\
\hline
\end{tabular}




\section{Appendix C: Interview Transcripts}

Marilyn Schleining Schultz (MSS)

Interviewed by Heather Viets (HV)

Steve Schreiber in Attendance

November 16, 2016

The Center for Volga German Studies

Concordia University, Portland, Or.

Transcribed by Heather Viets

Reviewed by Steve Schreiber

Revised by Heather Viets

HV: I'm Heather Viets, I'm a graduate student at Portland State University History Department and I'm doing my thesis on the Portland community of Volga Germans.

MSS: I'm Marilyn Schleining Schultz, and I am a descendant of Volga Germans.

HV: And we're at the Center for Volga German Studies at Concordia University. Okay, so I'd like to just ask you some general questions about your experience growing up in the community, and feel free to talk about anything that you feel is important. We don't have to stick to my questions. Can you tell me a little bit about your family background?

MSS: Let me go back to when my grandfather came to Portland. That was in 1906 . He had been a soldier in the Tsar's army, and of course the early uprisings in Russia were occurring in 1905, 1906. And as a member of the Tsar's army he was, he was targeted by the Bolsheviks as an enemy of the people. So, in the summer of 1906 he and his wife and their young son, who was just a baby, and that was my oldest uncle, decided they would leave. My grandfather's sister had come to Portland with her husband a year or two before and settled in the same neighborhood as many, many other Volga Germans. They were from the village of Norka, and so they came, um, by ship, of course, to Boston - when I was in New York years ago I thought they might have come into Ellis Island and I searched for their records there and there was nothing. But it turns out they came into Boston and then they took the train from Boston across the country. They came directly then to Portland. Um, at that time the German neighborhood was called Little Russia, and it was from about Seventh to Fifteenth and from Fremont to Prescott. And my, um, my family initially lived on Thirteenth, between Beech and whatever the street north of Beech is. When they arrived of course they didn't have any housing, so they stayed with my great aunt and her husband, and then sometime within the next year my grandfather bought property that was 
immediately north of his brother-in-law's there on Thirteenth. So ultimately, I think they owned five lots, five buildable lots on Thirteenth, on the west side of the street there. And, um, and in the next year my grandfather built a little house, and this is what it looks like today, and it was only about eight-hundred square feet, and they lived in that house until they had five children, in eight-hundred square feet, and my father said they used to sleep in shifts and there would be three people to a bed. And my grandfather built what they called the Big House and that's what that looks like [refers to photo]. It has been gentrified, um, it did not look like that when I was a child. It was much plainer. But this house-and then there's the lot in between that has what are now the garages, and then the little house. And then my grandfather bought this house that's next in line from his brother in law [refers to photo]. So, he just owned most of that block on that side. Um, and family lived in all these houses for year and years. When this became a rental house one of my cousins rented that for a while. And my oldest uncle - as I mentioned actually came from Russia - he and his wife actually lived in this house for years and years and years. And then in the early Sixties they decided they needed a nicer, fancier house and so they had one built right over here on Twenty-Third and Holman. So, they didn't get very far away, but it's a nice ranch style house and, um, and they were the ones who always had the Christmas parties. Um, this house had a basement with a bar and, um, anything you would need for entertaining. And so, they always hosted the Christmas parties there. And then when they built the house on Holman then the parties shifted to Holman. Um, and when they moved out of this house then another uncle and his family - actually, Jerry Schleining's parents - moved in here, and so this is where Jerry lived growing up and when he was in high school. And so, you know, this was the Schleining compound, if you will. Um, my parents did not ever live on Thirteenth. My mother was not a German from Russia. She was half German and half Danish, but not Volga German. And her family owned grocery stores, um, consecutively on Alberta. And, um, and they started with a very small little shop, and gradually got bigger and bigger, and finally had a big store on I think about Twenty-Fourth and Alberta-I don't remember the cross street for sure. Um, and they were in competition with Safeway, and they managed to force Safeway out because all the neighbor people shopped at their store, and they gave credit, and I don't think Safeway did, so that may have had something to do with it. But anyway, my parents, when they married, moved into a house on Borthwick, um, just the third house north of Fremont on Borthwick. And that was owned by my grandfather. Now, during the Depression, my grandfather, because he did not trust the government, having lived in Russia and knowing what an uprising does, um, never put his money in banks. And so, his money was all in a box under the bed, and so when the Depression hit, and people were losing their homes for lack of the ability to pay their property taxes, he went in and was able to pay the property taxes, and for that little bit of money was able to buy a house. And so, by the end of the Depression, he owned I think ten or twelve houses in the north and northeast area there. They were all pretty close by, so he could keep an eye on 
them. So, we lived in one of my grandfather's houses and we were there until I was in the fourth grade, and then we moved out to Rose City Park. Um, but I always felt like I didn't really quite belong with my cousins because we didn't live on Thirteenth or Twelfth where some of them lived. We were about ten blocks away, you know, but that seemed like a really big distance because the culture was different. In the old German neighborhood everybody still spoke German, and they cooked German foods, and it was, it was a very different atmosphere. On the street where I grew up people were of every nationality and, you know, it was a much bigger mix. When I was doing research for my book, um, I looked at the, um, 1920s census for Thirteenth. And you go down the list and it says, um, country of origin-Russia, Russia, Russia, Russia, all the way down the line. And then it said, um, I think it says native tongue or language German, German, German, German. You know, it was amazing. And most of those people, I believe, were also from Norka, so they were the same village and they just all kind of moved over and, and were very comfortable in that setting. Um, my grandfather never learned English - I mean he knew a few words, but he really could not carry on a conversation in English. Um, when he came, uh-now the 1920 census lists his occupation as scavenger. And he was a garbage man. And so, he, um, he was one of the first members - I don't know if he was a charter member, but he was a very early member-in 1916 of the Garbage Men's Union in Portland. And of course, I think they all were Germans from Russia. So, um, he started collecting garbage with a horse and wagon, and, and that long garage was like a barn for the horse and for the wagon. And then of course he switched over to a truck, and then several trucks, and then he had some commercial routes, and by his standards I think he became very successful. Um, one of my uncles did far better, and he went to Southern California in the early Fifties and started garbage routes there. And at one time he had a huge section of Los Angeles, uh, and he was very successful. Uncle Ad. Unfortunately, I did not benefit from his success. And so my grandfather, he could pick up garbage, you know, without having to learn the language, but he was also very good at handling money. And that's how he had, um, the money to buy all those houses and he was, he was a strict bill collector, so-well, I have rattled on.

HV: I'm happy to hear about all of that. That's really interesting. Um, can you tell me a little bit about your early years growing up in Albina and your upbringing?

MSS: I was born in 1937, and that was really the height of the Depression. And I think we were desperately poor, although people around us were also poor, and so you didn't really know, I didn't understand fully until I went to Grant High School years later and all of a sudden, the girls were wearing twenty-five-dollar Pendleton skirts, and my mother would have been appalled if I spent ten dollars for a dress. So, um, there, we were poor, and very thrifty, and my parents worked hard. Um, my mother, um, was very creative about ways to make money-I'm the second of four children in my family. And, so, when we were all small my 
mother didn't have a regular job, um, but she told about during - after my older sister was born, um, at the school that was just two doors away, Boise School, um, they had the women who were making, uh, all of the hand-crafted objects for Timberline Lodge and this, during the Depression, was part of the - what was it called? It wasn't the WPA, was it? The WPA. And so, they were making blankets and all kinds of things, and there wasn't a restaurant close by, and so my mother decided that she could serve lunch to these people. And so, she set up some tables on a little back screened porch, and also had the dining room with I think a couple of card tables, and so she would serve about twenty women every day for lunch, and then whatever food was leftover we had for dinner. So, you know, she was clever that way. And during World War II of course we had a victory garden, and so we raised some of our own food. By that time my maternal grandparents had sold their last store and bought a farm out at Clatskanie. And so, we got food from the farm. I'm sure we ate better than a lot of people. And of course, so much was rationed during the war, like butter and meat, and anyway. So, um, growing up I wore hand-me-down clothes from my older sister and also from the two girls next door, and it just never occurred to me that most people did not wear hand me down clothes. I was trying to think the other day if there were thrift shops then, and I don't recall that there were. There must have been a Goodwill. We certainly did not frequent any store where you had to hand over real money. We just mostly made do. The furniture that we had, I think it was all mostly second hand that people had given. Sometimes there would be things that my grandfather would get from the garbage route, you know, that people were throwing away. And, my dad had gone to Benson High School, and was kind of a jack of all trades. He could fix just about anything. He knew carpentry, he knew a little electricity, he knew motors, and so he was able to fix things. Um, my mother did a lot of canning. We had a dirt basement, but there were shelves down there with all the canned goods. So, you know, we did okay, but it was always a struggle. And, and I remember in asking $\mathrm{f} r$ things sometimes my mother would say, we'll see. And she didn't want to tell me no, but she knew she couldn't tell me yes. So, it was always, we'll see. And that kind of came to me as no. Even when I was in high school and, um, when I was a senior and getting ready for the prom, I made my own prom dress. But after I had already bought the material my mom said, you know, I think we can buy you a prom dress. And I thought, where did that come from? I wore the one I made. I did not buy a prom dress. So, growing up, I played with paper dolls a lot. Um, paper dolls were relatively cheap and there was a variety store over on Mississippi Avenue. You're familiar with Mississippi, with all the restaurants and bars - it was not like that then. There was the old Rio Theatre, and I think for a dime kids could see a show on Saturday afternoon. So that was popular. Um, on Mississippi Avenue we had the first soft ice cream store that I can remember, and it was called the Siberian. And it was magic because they would hold the cone under this machine and it would just pour out into the cone and they'd give a little twist, you know, and I thought that was the greatest treat in the world. So, it was always a struggle, you know, do I go to the movie, 
do I have ice cream, or do I buy more paper dolls? Um, oh dear, what else? My folks, for their entertainment, they did a lot of card games. They would meet, um, other couples, they'd come to our house or we'd go to their house, and the adults would be playing. I don't think they played things as complicated as bridge, or as sophisticated as bridge, but they had all these card games that they would play. Um, and yes, sometimes it was with aunts and uncles and sometimes it was with my dad's cousins, and sometimes it was just friends. Sometimes it was friends of my dad from Benson High School. When he first left Benson - and I'm not sure that he ever graduated, I tried to find that out and this is something my mother never would have spoken about, um, because my mother thought she was special, um, but I think he did not graduate, I think he dropped out and went to work, and at that time there was the Doernbecher furniture company. And Doernbecher was an old German man who hired lots of German boys, and, um, and so my father and my uncles, just about everybody, worked for a time at Doernbecher. And then in the late Twenties I think when Mr. Doernbecher died he gave money to start the Doernbecher Children's Hospital. But he was, he was just an old German who was making furniture, and it was, it was, um, it was hard furniture - it was tables and chairs and beds, and cabinets. Um, and it was in Sullivan's Gulch, the manufacturing company. So, it was, you know, very close.

HV: What kinds of traditions or practices were common in the community when you were growing up?

MSS: I'm thinking. I don't know so much about customs and practices. The women in the community had a schedule, um, you know, so they'd wash on one day, they'd iron on another day, they'd bake on another day, um, and it seems like Friday must have been baking day because, uh, we would go-my father and Ito my grandparents' house, and the prize was always a big - well, it seemed big to me then - a big round loaf of rye bread that my grandmother had made. Now, it wasn't my real grandmother. This is a picture of her. This was my step grandmother. Um, and my real grandmother died in the early Twenties with the birth of her eighth child. And the baby survived only a short time thereafter. But my grandfather had all these kids and needed help. And this lady had five or six children and her husband had died. So, they married and here is this huge house of children. And at that time, at the big house they built on some rooms on the back of it that it didn't originally have so there'd be more bedrooms, so in the back here they built on some more bedrooms [refers to photo]. You know, because - and she is the real grandmother of Harold Kammerzell, so-she's my step-grandmother, his real grandmother. Um, so there, there are all these connections. When I was going to Grant High School and I took German, um, here were all these kids whose families were from the neighborhood, and at the time I didn't think that much about it - I mean, you know, it's kind of just the way things were. Of course, kids from German families would study German. Why not? But, um, so, customs. Um... This grandmother was very religious [refers to 
photo]. She went to church several times a week, and it was Ebenezer Congregational Church, um, that's the one that I remember best, and that's the one that had the funeral services, um, for both my grandparents. Um, but she, she was far more religious than my grandfather was. He was, he was a businessman. But, um, and I think she was a little more old-school than he was, and because she was religious, it was like - well, if something happens it's God's will. And so she, she didn't have the confidence that somebody today would, would have and say, no, no, you have self direction and self will. But she was, um, she was a very good housekeeper, and cook, and baker. Um, she was not popular with my father's older brothers. Um, and, and I really don't know why. And especially when they lived next door. But when she needed something done she'd call my father and that's when we'd get to go, and we'd get the bread.

HS: I'd like to hear a little bit more about religion and whether that was a significant part of the Volga German community.

MSS: I'm sure it was. Um, you know, going back to Russia, um, I think that was, that was one thing that was very, very important to the villages and to the communities there. Um, when they came here, they still had their churches, andbut I think probably many of them were less religious than they had been in Russia.

HV: This next question we touched on a little bit earlier when you spoke about the garbage collecting services and Doernbecher, but I was wondering what kind of jobs were commonly held by people in the Volga German community?

MSS: There were some who were merchants. There were the Repp brothers who had the market on what was then Union Avenue, um, and there was a hardware-furniturevariety store just a couple of doors down from there that was owned by a Volga German - I can't remember, was it Weiner's? Weimer! Yes. Um, and so, I'm sure that there were some crafts people, um, George Arndt had a landscaping business. Um, what did Whitey Sauer do? I don't know. Most of my family were garbage men. Um, all of my uncles, um, my dad was not, but all of my uncles were garbage men.

HV: Can you talk a little bit about the role of language in the community and whether the old dialect was spoken in your family or in families that you knew?

MSS: Speaking to my grandfather, um, my father and my uncles always spoke in German. Um, old man Danewolf had the grocery store up on the corner, and if I remember right he spoke only German. If I went in there to get something I had to point to it. I don't think he spoke English. Um, all of the adults - I think that's fair - all of the adults there on Thirteenth spoke German. Um, my dad did not learn English until he went to grade school, and, and he went to Sabin, and I 
believe he was seven years old, um, and that was the compulsory age when you had to start school. So, you know, the, um, the community did not embrace education as we would wish they had. Um, but he was kept out-a seven-year-old can do all kinds of tasks - and, and so the kids were working, they weren't playing when they weren't going to school. Um, and then when they got to be eleven or twelve years old they were old enough to drive a truck. And, of course those were the days when you had to stop at every place and somebody had to get out and get the can, and physically, you know, carry it to the truck, empty it into the truck, and my mother knew all of that, and she said to my father you are never going to be a garbage man, because she was just afraid that it would ruin his health. And, um, so we were kind of the outliers. Um, she also did not like the fact that the Germans drank a lot of beer. Um, and so my father - we never had beer at home. But for the Christmas parties and times when he'd get together with his brothers he would drink a beer or two, but never to excess or he would incur my mother's wrath.

HV: I'd like to hear a little bit more about the role of women in the community. I know you mentioned that there was a certain schedule that a lot of the women seemed to follow with baking and things like that, but I'd like to hear more about it.

MSS: I don't know of any of the women there that worked outside the home. Um, they were pretty traditional, um, you know, most of them had children to take care of, and then they had grandchildren to take care of, and, so, um, I think their lives were not easy - and again, during that time period, the Depression and then the war, everybody was canning, everybody was raising vegetables, and all of that of course fell to the women to do. Um, and in none of these houses did we have central heat, so you had to have somebody who chopped the wood for the fires, for the stoves, and, um, and sometimes that fell upon the women.

HV: Those are all the questions I have but I'd like to know if there's anything else you want to talk about or anything we didn't get to that you think is important to mention.

MSS: No, not that I can think of. I think I've rattled on.

HV: I was very interested to hear everything you had to say, so thank you so much.

MSS: You're very welcome. 
Harold and Loretta Kammerzell (HK, LK)

Interviewed by Heather Viets (HV)

Steve Schreiber in attendance

November 28, 2016

Center for Volga German Studies

Concordia University, Portland, Or.

Transcribed by Heather Viets

Reviewed by Steve Schreiber

Revised by Heather Viets

HV: I'm Heather Viets. I'm a graduate student at the Portland State History Department.

HK: I am Harold Kammerzell, an individual that was born in the ethnic neighborhood of Northeast Portland.

LK: I'm Loretta Kammerzell, and I did not live in the area. I lived nearby, but my parents came from the area.

HV: And we're at the Center for Volga German Studies. So, to start off can you tell me a little bit about your family backgrounds?

HK: Yes, I'm a second generation, born here in Portland, in the, like I said, in the ethnic neighborhood. And, um, went to the schools in those areas, like Sabin and Highland, and of course, uh, the church was the center of the community, so I was raised in the German Congregational Church. Um, and our families all had businesses in the area, mainly refuse hauling, um, but there were several major manufacturers that other German families worked in, such as Doernbecher, B. P. John [Furniture Corporation], M. \& M. [Woodworking], Nikolai Sash and Door, and so forth. It was a very, uh, tight area, and it had its own shops such as butchers, grocery, hardware, dry goods, and we all-everyone patronized those, and we pretty much stayed within the neighborhood until the start of the second war, and that kind of dispersed everyone due to the war efforts.

LK: I have to comment on the grocery stores that I remember. The reason they had these little neighborhood stores were because there were no Safeways or Fred Meyers or any of the big-box stores. So, it seemed like every little area of the German area had its own grocery store. There were a number of them.

HV: Loretta, can you tell me a little bit about your family background? You said you were from nearby the area? 
LK: Nearby. My grandparents lived in the German area. Mom did until-both Mom and Dad did until they married, and then they moved roughly two miles away. But Mom did take care of her parents so that she was there almost every day. So when it came summertime and there was no school I was there every day for a matter of hours while she did housework and helped in the kitchen, and just more or less took care of Grandma as she was quite crippled with arthritis.

HV: Can you both tell me a little bit about your early years growing up in the Volga German community?

HK: It was kind of different because, uh, the people in the area all retained the language, the German language. And so, for us young guys, we had to communicate with the elders in the native language. And it was spoken - at our home it was spoken quite a bit around the table. Uh, in fact when I was in kindergarten, the teacher said you must speak more English, 'cause she could-I was mixing the English and the German together. And she said no, you have to speak English. But I delivered groceries in this area, and so working with the older women in the neighborhood, you know, they all spoke German to me and I had to communicate back. And although I've lost a lot of my German I can still understand. But uh, I'm having a little trouble communicating now. I've been away from it so long.

LK: In my home they spoke mostly English, but when they didn't want us kids to know what they were talking about, they spoke in German. But I could understand everything they were saying. I just didn't speak it quite as well or as often, but I could sure tell what they were saying.

HV: What was your upbringing like?

HK: It was kind of strict, we, my parents were Christian - were very, uh, associated with the church. We had, uh, we always said grace at every meal. We had prayer before bed. But everyone in the neighborhood pretty much did that. There were very few families that I can recall that didn't, you know, but as I said earlier the church was the center. And in the neighborhood, there were about four, five churches. Uh, what I do remember, it might seem a little funny, was before the war-you must remember I'm kind of a young guy - but there was a policeman named Barney that patrolled the German ethnic neighborhood, and uh, if any of the young boys got into trouble, he didn't haul them in or anything like that. 'Cause he knew the elders of the various churches, so he just went to the elders and said that guy, you need to reckon with. And so, the people took care of business.

LK: I find that my family, also, their life revolved around the church. That was our faith, but it also was our social life. It seemed like this is mostly what we did. 
HV: And that was the German Congregational Church?

LK: Yes, it was. And something interesting, you might find, is that we all went to Sunday school, and we went to-Harold and I went to the same church. He says he remembers me when I was five years old, and then we started dating when I was in high school, and then married. So, he's known me for a long time.

HV: Wow!

HK: Doggone.

HV: Can you tell me a little bit about any traditions in your family, like any important holidays?

LK: That's a good one. We always had a huge Christmas program on Christmas Eve, and the whole Sunday school-actually the whole church was involved, because it was the time that the little Sunday school children all, um, had a piece to say or a part in this, and the regular Christmas carols were sung. I always remember how huge that Christmas tree looked. It just seemed huge. And then after the pieces were all spoken and the songs, the ushers went back, came out with white sacks that had an orange in it, nuts in it, and candies. And that was almost one of the most exciting parts of the evening. And then you got to go home and Santa Claus usually had come while you were gone. How he knew, I don't know. And then all the German foods came out. Oh, we had so many wonderful things. Most families had German sausage. There usually were several kinds, and uh, I just remember a meat-type thing that was like a headcheese, it was called Stugen. And it was an ungodly grey color. It wasn't very appetizing looking. But we all seemed to like it. And then it went with our Riewwelkuchen. You had to have that, and rye bread, maybe some cheeses, but it was just a feast. And you got to stay up 'til almost midnight or around that time, and that was exciting to me. Didn't have a bedtime. So that was what I thought of for one of the holidays.

HK: Ours was similar. Very similar.

LK: Can you tell about Easter time when we had confirmation?

HK: That was a big holiday, Easter, again. But Palm Sunday, the Sunday before Easter, the confirmation class was graduated in front of the entire congregation. And um, and usually there was big dinners at the various family homes of those graduates, and it was, uh, a very festive time. One other- aside from the church thing, one of the major events of the year was the garbage men's picnic!

LK: That was not involved with the church. 
HK: No, it was really separate. And uh, it was a big to-do. At Roamer's Rest was one of the areas and Blue Lake was another. And um, the big part of that was, you know, the garbage men, they were in all the German churches, I mean the families, 'cause there was so many Portland garbage men. And so, they had this annual picnic, and this huge group got together and uh, had a day of just having fun at the picnic.

HV: Can you talk a little bit more about the garbage hauling business and, um, why so many Volga Germans were in that line of work?

HK: When they came to this country, in the nine-late eighteen hundreds, early nineteen hundreds up to 1910, 1920, these people, you know, they couldn't speak English very well. And although they came to this country and they were craftsmen - there was some, there was a lot of good ability amongst them - but because of the communication part, you know, they had to take - find lesser work. And they actually, um, most of them started the refuse business for the city of Portland. And, uh, one time I looked at the register. We had over six - no, three hundred and sixty-some families that were in the business.

HV: What other kinds of jobs did people in the community have?

HK: Because of their language, language barrier, a lot of them went-I shouldn't say a lot, but a number of them went to work in the railroad, like the Union Pacific and the Northern Pacific. Uh, in the railroad shops, maintenance shops, and down in the Albina district. And uh, of course that was all within walking distance from the neighborhood. So, there was an advantage there. But a lot of them-because they were very good at woodworking, cabinet making, carpentry, uh, real detailed work - woodwork. You know, they found jobs like at Doernbecher Manufacturing, furniture manufacturing. And M. \& M. Woodworking.

LK: B. P. John's.

HK: B. P. John's, Nikolai Sash and Door. There were a number of large companies at that time where they also could find employment.

LK: That's where my father worked, before he got into the garbage business.

HK: Speak up. Your voice, they can't hear.

LK: My father worked in the furniture business from the time he was fourteen I believe. And then he eventually had a milk route where he went out to the outlying farms and picked up those big milk cans, hauled them to the, uh, dairies. From the farm to the- 
HK: Creamery.

LK: Creameries, yes. And then he went into the garbage business. He retired from that.

HV: Can you tell me a little bit about folk medicine and healing in the community?

LK: Yes, I can. My grandmother was the doctor, midwife, everything, for the German people, and they all seemed to come there. There was another doctor named Dr. Uhle that took a lot of the German people. And um, but Grandma was the one that they came to mostly. And she did like chiropractic-type work. But all of this was because she was a natural healer. God gave her this special gift-she could hardly speak any English, and yet she just had a touch where she could heal. And I honestly saw people that had broken bones that she set and healed. I saw the man across the street had chopped-he was chopping wood, and he accidentally cut off his thumb. Totally cut it off. And he carried it over on a bread wrapper, ran across the street, and I was there at Grandma's, saw this happen. And I watched her, "cause I used to sneak up the stairs and peek into that room and watch her. It just amazed me. And she would mold it. Her fingers were just like this, and she set that thumb on there and it totally healed back. My brother had his - as a baby he was about, oh, two years old maybe, riding on the back of my bike, got his heel caught in the spokes. I was going so slowly, just giving him a little ride, but it tore his heel off. It was just hanging by skin, and she just molded it back on. And I was told I'd better be babysitting him every day. He was to lay on a blanket out in the sunshine and let that heal. And Grandma had taken adhesive tape and somehow with gauze and that tape she made like a cast, and it just fit on him. And they'd take that off every day and he'd play on a blanket out in the sunshine. And I had to every day play with him and keep him there. And that healed, and he became a Marine, ran marathons, and you - that heel never has bothered him. You cannot see a scar. There's nothing there.

HV: Going back to religion a little bit and the church, um, can you tell me more about the role of the church in the community?

HK: From the standpoint of, politically? Or-

HV: No, just from your experiences. So, you said that it was kind of a community gathering spot. Do you want to talk about little bit more about that?

HK: The church we were raised in had, uh, a lot of functions. One was that during the war the elders of the church got together and said, you know, we need to do something for the young people here to keep them going, uh, occupied so they don't go astray. So, they started a band. They hired a musician, and he came in 
and he taught these kids - I have a photo of it - um, how to play instruments. Actually, I attended the very first session of his training. And he, uh, the first six, eight weeks, we didn't even touch an instrument. It was all bookwork, you know, notebook work we had to do, and learn about music. And then he brought instruments in and he tested everybody, you know. He gave you a choice, you know, he said what could you - what would you like to play? And uh, you would say, trumpet, trombone, whatever. And he would try you out and he would say no, you should try this instrument. And that's the way he trained. And a lot of these kids went on to-fantastic musicians, they were all, um, what I'd call leaders, instrument leaders, in the schools that they attended. And um, in my case I, uh, I went on to be first chair trumpeter at Benson Polytechnic. And I was also northwest, uh, honor guy, for trumpet playing in the Pacific Northwest, in awhat would you call it? Contest? And I made all-city band, all-city orchestra. And a lot of the kids that I grew up with that started in this class did the same, and the following - they were very good musicians. And then later on a different pastor came to the church and he started what he called a-he said I want to start a youth group, you know, just keep you together. Called the Alumni Association. And you had to graduate from confirmation, and then you got to go into this alumni group. And we conducted a lot of things - had picnics, we had, uh, gosh, all kinds of stuff, didn't we? I can't even remember.

LK: I have to correct you a little bit, because you didn't have to be from the confirmation group, but that is the nucleus of it. But there were some that didn't. But I would like to also comment about the music. I was not one that was in the band. Uh, at five years old I started taking piano lessons until I graduated from eighth grade, and I had continued to take until I was about fourteen, and then because I was so in love with music and evidently did quite well, my mother wanted me to take pipe organ. She had a thing for this - sound of music, and I really liked it. There was one program on the radio, and every time that came on with this pipe organ music I used to always go and just lay my ear against the radio so I could really hear it. So I started pipe organ lessons. And at the church that we went to I started playing full time, and I was seventeen, I was their organist, and I've been playing organ professionally ever since.

HV: Was there traditional Volga German music that you played, or what kind of music was it?

LK: Just the old hymns. That was mostly it.

HK: I'm not very knowledgeable about it, but there was a band, uh, kind of a oom-pahpah band. And there was a Starkel guy who, he played for dances, Saturday night dances. And there was a store on Union Avenue called Weimer's Hardware and Furniture, and upstairs they had kind of a dance hall. And the Starkels would play there, and other musicians. Hildebrandt was another guy I knew that played the 
fiddle, and her [Loretta's] uncle was an accordion player that played for dances in that same location. It was, uh - the hall was used for big wedding receptions. People then behaved themselves.

HV: Can you talk a little bit about women in the community? What kinds of things did women usually do?

LK: Way back, I can show you a picture of the Ladies Aid, is what I would call it. I don't know what they called it in German, but this is probably when I was young or just before my time, so you know how old [refers to photo]. But this is a group of the women that got together probably once a week for Ladies Aid meeting, and I'm sure they had some projects I'm not sure about. But my grandmother's in this picture, so.

HV: Was that a Volga German group specifically?

LK: Yes.

HK: Yes.

LK: This is probably just from our church. And each church had a group of women like this.

HV: Harold, do you have any thoughts about women in the community, or-

HK: They were always after me 'cause I couldn't behave myself. I can still see, picture them running after me shaking their hand.

LK: What I have to add to that though, is in that era women didn't ordinarily work outside the home. You were a housewife, you stayed home, and people usually didn't have cars to get places, so their life basically was keeping up the home, taking care of the children.

HV: $\quad$ Those are all my questions, but I was wondering if there's anything else that you'd like to talk about that I didn't bring up?

HK: The ornery stuff?

LK: You could tell about going to Seesa's farm. ${ }^{138}$

HK: We had a Volga German couple that lived in Ridgefield, Washington, which at

${ }^{138}$ The spelling of this name is unknown. 
that time was a little distance from the neighborhood. And my grandparents on my mother's side would go out there once a week to get fresh cream, eggs, butter, milk, uh, to bring back to the neighborhood women for their baking. They usually did this on a Friday morning, uh, and I got to ride with them a couple of times to go over there and come back. And then my brother and I had the job of delivering that throughout the neighborhood. And, uh, we did this for quite a while. In fact, my mother was so proud of us, going around this neighborhood to all these German women, and furnishing all the eggs and milk and cream, and um, she went and bought us overalls - the blue and striped overalls like the professional milkmen used to wear when they delivered milk through the neighborhood. And everything went well until one Saturday my brother and I got into an argument and we tipped over the wagon with the eggs and the milk and-and we got fired. We lost our job. But it was exciting because, mind you, we were delivering this stuff in the morning, Saturday morning, and that's when all these ladies were baking. And you know, by the time we got through with our route, uh, you know, we had cookies, we had Grebble, we had all kinds of goodies that the ladies were giving us. Uh, yeah, we didn't need lunch.

LK: Some of the names of these foods that you might be interested in is the women, when they would bake, would, um - first of all we had German rye bread. And it was a light rye that they used, not a dark rye. And, um, that was a weekly thing. Probably some women baked more than once a week. And then they made what we called Riewwelkuchen, that's one name, and it was nothing but a bread, just a white bread, with these crumb - um, what would we call that? A butter, sugary crumb topping. And then we also had, they'd use the white bread dough, and you would roll it out, very thin, cut it into squares approximately this big, and you'd fill it with usually hamburger that you'd browned and cabbage that you steamed down, and that was your filling. And then you'd bring the points up, pinch them down, flip them over on a sheet, and bake them. And so that was our either Friday night or Saturday night dinner every week for a lot of people. And, um, I can't think of any other-

HK: We had Grebbel.

LK: Grebbel would be like a doughnut, a deep-fried doughnut, but they would cut them in a rectangle with two slits and you-it was a knack to learn how to twist those, drop them into the hot oil, and fry them. And that was one of our big desserts.

HK: We had an unusual soup called Schnitzsuppe. It was a dried fruit soup, you know.

LK: Schnitz means cut.

HK: Cut, yeah. And it was dried fruit soup and it had cream- 
LK: You first boil that, and then after the fruit has softened then you add sweetening - Mom always used molasses, a little bit of molasses and cream - and you eat it hot. The Scandinavians eat it cold. But, um, the Germans always had it warm or hot.

HK: What was so funny is about half of the kids in the neighborhood, you know, if they knew they were having Schnitzsuppe they'd run home. The other half, find out they're having Schnitzsuppe, and run away! They didn't like it.

LK: Our family always had the Grebbel with the Schnitzsuppe. A double treat.

HV: Thanks so much for talk to me today. It was really nice to hear all your stories.

Loretta Kammerzell passed away on March 22, 2017. Her generous contributions to the Portland Volga German community are fondly remembered. 
Roy Derring (RD)

Interviewed by Heather Viets (HV)

Interviewed by Steve Schreiber (SS)

December 4, 2017

Center for Volga German Studies

Concordia University, Portland, Or.

Transcribed by Heather Viets

Reviewed by Steve Schreiber

Revised by Heather Viets

HV: We're here at the Concordia University Library in the Center for Volga German Studies. It's December Fourth, 2017. I'm Heather Viets.

SS: I'm Steve Schreiber.

RD: I'm Roy Conrad Derring.

HV: Roy, I'd like to ask you a few questions about your experience growing up in the Volga German community. Um, so first, can you tell me a little bit about your family background?

RD: My father was born in the Volga region of Russia, Volga German. Um, he immigrated here in 1912. My mother's from northern Norway, from a place called Kjerringøy, and uh, that's pretty much it for starters.

HV: Can you tell me a little bit about growing up in Albina in the Volga German community?

RD: I actually didn't grow up in Albina. There were other neighborhoods

$\mathrm{T}$ hat did have, uh, Volga German immigrants. I was actually born not far from here in Woodlawn [Northeast Portland], and still have the family house, since 1940.

HV: What kinds of traditions or practices were common in the community when you were growing up?

RD: We didn't attend Volga German churches, which there were, like, three churches?

SS: $\quad$ There were actually more than that over time. There were probably four primary churches, but there were a number of other churches that also had Volga German members. Sometimes they were mixed with other ethnic groups. Um, but there was actually a small Mennonite Baptist church just north of Fremont on 
Sixth, which was founded by a fellow from Norka. But it was kind of out of the mainstream of other churches.

RD: We visited neighbors. That was where I would hear German, the dialect they spoke in, and although my sisters and I - and I had four sisters, older sisters they didn't really know, learn any German. I heard a few phrases or words that my father spoke, but essentially, we were just all-American kids. And I didn't know an awful lot about, uh, where my father came from, or for that matter where my mother came from. But we were surrounded by more of the Norwegian relatives than the Germans - Volga German relatives.

SS: Roy, were you ever encouraged to learn German, or did you just pick it up by, by listening?

RD: I did take, um, freshman high school German, and that was about it. That got me going more. But then I pretty much picked it up and then I would hear my father say things, and then I was stationed in Germany in the army for two years, and, um, ironically in the same area-I didn't know it - but in the same area where Germans immigrated from Germany to Russia.

HV: Wow, that's really interesting.

SS: I'm just curious, when you were there in Germany did the dialect sound familiar to you or was it a little bit different or-

RD: No, in fact, I tried my dialect at um, at this, well, it was an on-base restaurant but it was run by Germans, and I tried my dialect and it was like they didn't quite get what I was saying. But I really, uh, didn't practice that much.

SS: Right.

RD: But I would understand, though, when I would hear it. But I think I was a little hesitant and self conscious that I was making grammatical errors, or, um, so since then I became better at that. I wasn't self conscious, and if I made grammatical errors, well, so what.

SS: It was a dialect that had evolved, you know, over two hundred years since our ancestors had left that part of Germany, so probably a little bit different than today.

HV: What kinds of jobs did people in the community usually have?

RD: A lot of them, including my father, worked in furniture, uh, furniture- 
SS: Manufacturing.

RD: Manufacturing, yes. And uh, my father was a wood finisher. After the cabinet makers would make the cabinets or the, uh, fixtures, he would spray them. He was, that was his job.

HV: Okay.

SS: Was he at Doernbecher's, or-

RD: He was at Doernbecher's, yes. Doernbecher was a German, and-were they Germans from Russia or just-

SS: $\quad$ No, I think directly from Germany, but they hired a lot of Volga Germans, as did B. P. John's.

RD: B. P. John's, my father worked at B. P. John's. My father also worked -I remember as a kid, like five years old, going to downtown Portland where he worked right on Fifth near Burnside, and it was called Stadler Fixture Works, and there were other Germans there. So, they spoke German a lot because they were in the, that business together. And I think, um-I discovered later that, um, they all, the Germans from Russia that were here also worked on railroads. Is that right?

SS: Yeah, a lot of them worked for the railroads, and as you know, a lot of them got into the garbage hauling business -

RD: Oh, absolutely-

SS: Heather and I were talking the other day about, um, the relationship between Volga Germans and Germans from Germany. Do you remember anything about that or hear stories about that? Did they get along okay together or not get along okay?

RD: No, I think they got along once they, you know, discovered they were German or when they, they would speak with each other, it didn't seem to matter so much if they were from Germany or if they were from, uh, the Volga, from Russia. Uh, it was that they connected because of the language. The language, they connected because they spoke German. We had neighbors from Germany and um, so my father always spoke with them and they spoke with him and it was, uh, a real connection for them.

HV: Those are all the questions I had, so Steve, if you have any- 
SS: Why did your dad decide to come to the U.S. and you know, were there relatives who were already here or what kind of spurred him as a young man to come to the U.S.A.?

RD: He was receiving letters, or the family was receiving letters from America from his oldest sister, Louisa, and her husband, uh, Henry Blum, and at that time they were married - they had married in Russia and then they came to America. Also, I believe it was around 1904 when they came. And then his oldest brother who was ten years older already had a family in Russia and they immigrated as well. So they had an - they were established here, and then they were receiving letters in Russia from them, and um, my father was just chomping at the bit. He wanted to go to "America, America." And uh, and I believe that my grandmother really wanted him to go. Uh, my grandmother, whose leg was amputated and who was very sick [refers to photo.] She looks like she's probably close to ninety but she was still in her fifties, and she's so pale you can't even see the features of her in the photograph. I really felt awful about that, and when my father would talk about missing his mother after he came over, he would kind of choke up and tear up, and you'd go to console him - but he didn't want, he didn't want to be consoled. He wanted-I mean, that was his thing to feel like he didn't want to be.

SS: $\quad$ How old was he when he came over?

RD: He was sixteen.

SS: $\quad$ Sixteen.

RD: In this photograph here he was already, um, well he could have been fourteen. He said because of this photograph he was standing on his tip-toes. He didn't want to look short. His brother was tall, but he was short. And I think he was-

SS: I think I remember doing that when I was younger too.

RD: Yeah. And I think he was hitting his sister in the side-everyone, their mouths are all turned down. I think, you know, when you had photographs taken at that time or you've even seen others from the Wild West or something, you had to look serious. They were so-

SS: I was told by one elderly Volga German woman once that, she said, wellphotographs or photography during those eras, you had to kind of stay still longer, so it's hard to even hold a smile. But even beyond that, kind of culturally, they thought it you smiled there was something wrong with you. So, you wanted to be more, kind of, serious. And there's still, I mean, cultures, like in Asia where if you smile they think you're a little bit goofy. They don't take you seriously, so you have to- 
RD: That's right. So, they had that somber, very serious look on their faces and they look - they were very poor as well. I mean, you can tell, and the thing is my grandfather wasn't in this picture because he, prior to this picture, um, that was taken, he froze to death on a sleigh that was coming back in the winter time from another village. He was a meat cutter. And so, they lost their father and for a woman to lose her husband is like losing a leg or an arm. Well, literally, my grandmother did lose a leg, and it was because she was diabetic. But um, so it was very difficult raising, I think it was six kids. And her two oldest, her, uh, oldest daughter and her oldest son, were married and they left. So, there was - the older ones weren't there to take care of the younger ones in the family. And the two old - these brothers - were in the military, from 1914 to 1917, and the only thing that saved my uncle Adam from the firing squad was because he was a prisoner of war, so, the war was over, and the revolution had already taken place, so when they came back they were indoctrinated and not treated very well. And at that time all the livestock was taken away from the Germans. All the farming equipment was taken away. All the seed grain for planting more crops was taken away. And that was one of the worst parts. That was a systematic thing that I strongly feel was, um, to starve these people to-starve them, which came about where they had the famines of 1921, was it-

SS: $\quad$ Early 1920s, and then again in the early 1930s.

RD: So, these were very hard, bad times, and not only that but when my father was here and his sister and her family and my uncle and his family, there was no longer communication with Russia. You couldn't send letters back and forth. I think it - I can't remember when exactly that stopped but during the revolution in certainly interrupted all communication. So, my father didn't know what happened to his mother, he didn't know what happened to his brother Peter, his sister Anna, and what happened to the two brothers. And it was learned later that, uh, the brother Johannes faced the firing squad-returning veteran. Um, and, there was a story that my father told me he had heard that he had a chance to get away, but he didn't want to dessert his friends, his comrades that he was in the military with. There could have been as many as seventeen of them. And uh, let's see.

SS: Was part of the reason that your dad came over, do you think, was to avoid going into the military? Because he kind of got out a couple of years before he would have been enlisted.

RD: Yeah, because the war in Europe didn't start 'til 1914, I believe. And at that time when my father immigrated it was 1912 . They were-I'm sure they really wanted - there were many reasons that they wanted to get him out and they would have needed my aunt to be there for my grandmother, and uh, Peter was there. I, I 
don't know, you know, exactly what his feelings or what his thoughts were about the whole thing. That his little brother got to go and he had to remain - why, why him? And uh, so it was - from the time that communications stopped until up in the-near 1970, I think it was 1969, so we're talking about over fifty years had passed with no communication. Not knowing what exactly happened. Knowing there were deaths but not the circumstances. My father, through someone who had a barber shop not far from here up on Ainsworth and Thirtieth, um, the building's still there, I think it's a little restaurant or something like that, I'm not sure exactly, but this barber who was of German from Russia extraction, uh, was able to help my father, uh, to find out how he could get in touch with his sister in Russia, where in Russia or even that he knew that he could find her. So the barber told my father to-here's a man who owns a locksmith shop on Union Avenue which is now MLK [Martin Luther King Jr. Boulevard], um, that, to go see this man and he can help you. So my father went there, and I remember hearing this at the time. And so I was happy that my father could find out, but I wasn't interested-I didn't have the desire - it wasn't in me yet to, to be involved with it. And so my father did get my aunt's address.

SS: That's amazing.

RD: I don't know how, but that man helped.

SS: Were they in Siberia, or-

RD: My aunt was in Siberia. My aunt Anna Katrina. So they maintained this back and forth. And I remember being with my father at the post office downtown where he was sending a letter off, and then he got a letter back, he got several letters back, and he got a letter back that_-“don't send money," because he was sending maybe ten or twenty dollar bills or whatever, because it would be confiscated. I don't know if she said it would be-just "don't send the money." Now, at the time I was very happy for my dad that he was getting this correspondence with his sister, yet I was still not involved. It just didn't really connect inside for me.

SS: What was the trigger for you? When did you get-

RD: I didn't really get interested until I found out while I was watching TV - since then my father had passed away about eight years ago in 1981 and this was 1988 in the summer, and on television there was a, I think it was called neighbor fair, or neighbor food fair, neighbor fair, and it was, um, down at the waterfront. And there were all these ethnic groups that had booths. And they were also having performances by different places and crafts and things. And I was, just happened to have the television on and watching that, and it came up to the Volga German booth - what? And I just, that's what sparked me. And I was so curious. A Volga German booth, you know, I had never heard of anything like that. Uh, something 
that got my interest, and my father's Volga German, and so I looked in the phone book and I found the, uh, the church, the one on Fremont, and Seventh? Or not Seventh-

SS: Probably Ninth.

RD: Ninth, yeah. And I called the church up, and they referred me to, I think it was Cliff Haberman and Heimbuck?

SS: John Heimbuck.

RD: John Heimbuck. Those two. And I got ahold of them and that got me to where the meetings were held, and I joined, and I was very enthused and got into it. And uh, started digging up little photographs that I re-photographed and had printed. And, uh, so I was looking for my father's - his bedroom was still like it was. It was funny "cause, well one funny part was that here he had a little box and I opened up the box and there were a couple of cookies that were still in there after all those years.

SS: Just a little stale.

RD: Yeah, a little stale. So, I was also looking through other stuff and I found part of his passport, and uh, some other things. His, some other thing, it could have been confirmation or something like that. And um, then I was looking for the letters that he got from his sister because I wanted the addresses, primarily so I could get in touch with, uh, I don't think she - she probably wasn't alive, but there would have been cousins who would have been pretty old, and it would be like second cousins maybe that I could get ahold of. But my father at that time, in later years, he was developing Alzheimer's, dementia. Um, so he had destroyed his letters. He threw them away. And I remembered them being there but then he-uh, didn't do it intentionally. It was just, he didn't know what they were anymore. And uh, yeah. So my interest really grew from back in that time.

SS: What are some traits that define Volga Germans? Because you've got Norwegian ancestry, you've got Volga German ancestry, so you can kind of compare the two.

RD: Yeah.

SS: What would you say are sort of, maybe unique things about the Volga German culture, traditions?

RD: The unique part I guess was the language, but that's really died out which is too bad. Uh, and, we were just like, when I was going to high school I saw all these names in the yearbooks that we had, uh, they called them Spectrums, and 
uh, everybody - there were so many people that had German last names because the Albina students went to Jefferson High School. Some on the other side of Fifteenth might have went to Grant. Some went to Benson, or some of the girls went to all-girls polytechnic school. One of my sisters went there, and another went to Commerce, which was a clerical school-

SS: It's now Cleveland.

RD: Yeah, Cleveland High School. And uh, so, uh, at Jefferson all these kids with German last names, and yet none of us - none, I was never approached, I never approached anyone - it wasn't even in the consciousness of their last names being German. No one came up to me and said oh, are you of German extraction? Volga German extraction, or descent? And uh, I would never have thought of approaching them that way. What we were, what we really were, and I really strongly feel this, we were all American kids, doing all American cultural things. And uh, in 1955, rock and roll was just happening, just beginning. Uh, not that we didn't listen to other stuff before that. But it was totally all-American, and we listened to the radio programs, the mysteries, the comedies, the variety shows, and it was like this magical radio that would spark your imagination. You had to imagine what they were doing, what they were saying. It was like reading a book, you know. So, it was - it was just, we were immersed in American culture. Now-

SS: Do you think that's in part because, like, you said your family sort of assimilated very quickly. So, after hundreds of years of being in Russia, where they actually chose not to assimilate, or they chose not to take on the Russian language or many of the Russian traditions - they very rapidly sort of gave up their Volga German identity - public identity - when they got here to the U.S.

RD: They did. And it was to their advantage, so they could progress, and every generation progressed on from then. It wasn't like they were stuck down, and it wasn't like they were living in a ghetto in Albina. They were, uh, functioning out of - now I would say that a lot immigrant women that were Volga German women who had families, who were stay at home, raising good families, they - a lot of them, well, older ones, maybe they came when they were already in their upper thirties or forties - um, they maintained more, I think, of the-

SS: $\quad$ They didn't assimilate as much.

RD: They didn't assimilate as much. Their assimilation was going to the grocery stores, maybe some businesses to buy some things, um-

SS: But those would have been sort of typical neighborhood Volga German businesses. 
RD: That's true. And uh, there were no real large stores, like supermarkets until about 1950. Wait. Actually -

SS: $\quad$ Fred Meyer.

RD: $\quad$ Yeah, Fred Meyer and Safeway were-

SS: $\quad$ Fred Meyer was on Union and Killingsworth?

RD: Killingsworth, for a long time. And I remember seeing Fred Meyer himself in the downtown Fred Meyer, which was on Fifth and, I don't know, it could have been Yamhill or Taylor.

SS: $\quad$ So why do you think people like you and I continue to be interested in this topic? What's your theory? Your father, you know, wanted to assimilate, my parents were pretty well assimilated because they were first generation born here. So, what's your theory - why are we so interested in it?

RD: I think we also have an identity. Or we had an identity crisis - I don't know if it's a crisis, but it was an identity. Because we were not just-let me see how I can phrase this. We were not just a, um, just Caucasians. We have identities, we have cultures, and I think it's that way with many people from Europe. We're not just Caucasians, we're Germans, French, Irish, Dutch, Scandinavian, Eastern European, and uh, I think people want it to be known that you're not just white or Caucasian, that you also have a culture that got you up to this point. You didn't just come out of nowhere. You have a background that led you up to where you are now. And so I think when a lot of - so many people did assimilate, and the language was lost, they were trying to get it back and you don't completely get it. We love America and we love the American culture and what it has afforded us being here. That's why people all over the world want to come to America. So, and-

SS: I think I know the answer to this question, but if you had to sort of rank your identity - we have kind of at least three different identities. We're American, but we have this Russian kind of connection for several hundred years, and then we have a German connection even further back. I mean, if you're identifying yourself, what's the ranking or how do you kind of see yourself in terms of those three different cultures?

RD: It's funny because I was around Norwegian culture more.

SS: Right, you've got four. 
RD: My sisters were more, you know, into the Norwegian side because we saw our Norwegian family relatives, aunts and uncles, and uh, and I would hear my mother speak in Norwegian with my grandfather. And so, and he would come and visit quite often. But I guess I felt like I identified with that because I was able to interact with it. But I didn't have it with my German side. I had it with my father because my father told me stories and the stories were like in here [refers to photos] of his growing up in Russia and then coming to America. Uh, so I didn't really have that - I'd go around with him to visit with other immigrant Germans and I would hear them speak in the language back and forth.

SS: Were they mostly conversing it that dialect?

RD: Oh yeah, and of course they'd pick up American words to because, uh, so it'd be a little sprinkling of English mixed in with the German and it was kind of different because-

SS: I think they call it Dinglish-Deutsch and English.

RD: I was never in large groups of Volga Germans, and my father was - we didn't live in the concentrated area of Albina. I think my, my father would go there every week, he'd go there but he'd escape from there-

SS: That was kind of his cultural fix, if you will.

RD: He'd go there, and a lot of the culture was in the taverns down there.

SS: He went down to share a beer with his comrades.

RD: Yes, and I'd tag along with him so I'd hear all this, and um, but I had no one to speak with because it was-everybody, all the kids that were born here were speaking English, you know. Um, so, but it was fun going to the taverns with him because it was lively. I got to go play the jukebox, and I-he referred to me as his bodyguard. And my father would be around-here's all the garbage men. Mostly garbage men in the taverns. And they had their little allowance to go have a beer. And my father, who was-he would always dress up when he went down there. He was in his double-breasted suit. He would be fully dressed. He was quite a sharp dresser, and uh, he would have his diamond rings on and his jewelry. And here he'd come in and here are all the garbage men in their garbage men uniforms, and uh, they'd love to see my dad come because they'd say, there's Coonie. Coonie is a nickname for Conrad. Coonie, or they'd say Kuh-nee, in the dialect it sounds different. But um, so he would always buy beers, you know, set them up for everybody because he didn't want to be like the poor boy from Norka. And he came out of a poor existence because no father around anymore, and then the older ones leaving, and so it was pretty grim circumstances facing 
the whole family, and the fact that he got out and he was able to get good employment and uh, buy the food he wanted-he would always shop in the markets and come back home with sacks full of, you know, meat and bread and it was like a sin if you didn't have it - if you didn't have bread when you were having dinner that was a sin. You know, you had to have bread because bread was - took him back to here [refers to photo] and bread was always the filler. If you were hungry you had to have bread. So, there was more than just eating bread - it was, it was the staff of life. Um, so-

SS: $\quad$ He was kind of showing that he'd made it. He was buy food and nice clothes and he'd buy a drink for his friends. He was living the American dream.

RD: That's right. And in German he would use the phrase all the time, "Arbeit macht das Leben süss." Work makes life sweet. And so, the work ethnic among Germans generally, culturally, was - the work ethnic was there. And so-

SS: If you worked hard you could improve yourself.

RD: Yeah.

SS: I think that was all the questions that I had. So, thanks, Roy, for being willing to do this and talk with us and share your stories.

HV: Thank you so much.

RD: My pleasure. Thank you very much. 
Steve Schreiber (SS)

Interviewed by Heather Viets (HV)

February 19, 2018

Written interview via Email

Reviewed by Steve Schreiber

Revised by Heather Viets

HV: Tell me about yourself and your connection to the Volga Germans.

SS: I was born in Portland in 1956, the youngest child of Fred Schreiber and Esther Smith (Schmidt). I was brought into the world by Dr. Uhle, who served the entire Volga German community in those days. In my early years, we lived in the eastern section of the Volga German neighborhood at 4037 Northeast Thirteenth (between Shaver and Mason). My paternal grandparents lived down the street from us and there were many aunts, uncles, and cousins living nearby. I attended Sabin Elementary School. During the turbulent 1960s, there was a good deal of tension in Northeast Portland that created anxiety and some fear. My parents and grandparents moved out to the Gresham area along with many other people in the old settlement. I finished my elementary school education at Lynch Terrace and then attended Centennial High School. After high school, I attended Oregon State University and became the first person in my immediate family to graduate from college. After college, I worked for a CPA firm in Portland, then for the Port of Portland for over thirty years. At the Port, I served as both the Chief Financial Officer and the Director of Aviation with responsibilities for four airports, including PDX. I married Roz Hinchliff (of English and Irish descent) in 1989 and we have two children, Will and Lizzie.

HV: Who were grandparents?

SS: $\quad$ All four of my grandparents were Volga Germans who were born in Russia. My mother's parents, Johannes and Anna Margaretha Schmidt, lived in the colony Brunnental (Spring Valley) and arrived in Quebec in 1907. They immediately came to Portland by rail. My father's parents came to America separately. My paternal grandmother, Elisabeth Döring, departed the colony of Norka with her parents, Heinrich and Dorothea Döring, late in 1903 and arrived in Philadelphia on January 4, 1904. My paternal grandfather, Gottfried Schreiber arrived in June 1908 traveling on his own. Gottfried had two older brothers who had come to Portland one year earlier. My grandmother was about ten years younger. They met in Portland were married in 1918.

HV: Why did your grandparent come to the U.S.A.?

SS: I wish that I would have asked them that question while they were still living. 
Based on stories and some documentation the reasons seem to be as follows:

1) Poor harvests in the early 1900s led to food shortages and hard times in Russia.

2) The population was growing and there wasn't enough land for everyone to farm.

3) There were early indications of a potential overthrow of the Czarist government of Nicholas II.

4) The Russian government had taken away many of the privileges granted to the Germans by Catherine II in the 1760s including exemption from military service and the right to have their own language and schools.

5) Positive reports from family and friends who had come to America beginning in 1875 encouraged migration.

6) Some pastors, such as Rev. Wilhelm Stärkel (who served the Norka parish and had connections to Brunnental through the Brethren movement), encouraged their parishioners to go to America.

HV: Did you grow up identifying as a Volga German? If not, when did you become aware of your ancestry?

SS: I had no idea that I was part of a Volga German ethnic group until I was in my late 20 s or early 30s. I never heard the term "Volga German" when I was growing up. I did hear people use the term "Our People" but I wasn't really sure what that meant at the time. Discussion about life in the "old country" was done in German and we kids couldn't understand enough of the dialect. I was fully aware that we were German. Parts of our church services were still in German when I was younger, and the older folks conversed in the dialect. Some songs were sung in German. The part about living in Russia was a mystery until I was older. I used to ask my parents where our family lived in Germany and they told me their parents were from Russia. I thought they were confused and meant "Prussia!" Why in the world would Germans be living in Russia? It wasn't until my mother died in 1994 that I really developed my interest in family history. My mother had documented what she knew about the family and had joined an organization called the American Historical Society of Germans from Russia. As I began looking through what she had collected, a sort of "secret world" opened up and for the first time I began putting the pieces together about my grandparents and their ancestors. I was fortunate to be tutored by some of the older members of the Oregon Chapter of AHSGR when I first became interested in my family history. People like Marie Trupp Krieger and Bill Burbach added greatly to my knowledge about the Volga Germans and freely shared their photos and information. I was also fortunate that the timing of my research coincided with the opening of the archives in Russia. Information, such as census lists and church records that we thought had been destroyed was discovered and we continue to find more information. It was an exciting time. Many of us can now trace our ancestry back to the places of origin in modern Germany and other parts of Western Europe. I've connected with branches of my family that are living in Russia, Kazakhstan, and Germany. I'm 
still learning more twenty years later. The fun part of genealogy is finding connections to living people that I wouldn't have otherwise met. I made a trip to Russia in 2006 with a cousin who lived in Norka and was part of Stalin's deportation of the Volga Germans in 1941. He had not been back to his home village since that time. It was a very emotional experience and one that I will never forget. The famines and deportation were never discussed in my family when I was growing up.

HV: Did your parents and grandparents associate with other Volga Germans?

SS: $\quad$ Yes, I think the majority of their social group was family and friends from our church who were also Volga Germans. The church was in many ways the social center of the community as well as the spiritual. We attended the Second German Congregational Church (later the Evangelical Congregational Church). My father's family was part of this congregation. My mother's family belonged to the St. Paul's Evangelical and Reformed Church, but I only visited there on rare occasion or perhaps for a funeral.

HV: How did the Volga German community evolve over time?

SS: $\quad$ As you know, the first group of VGs who were living in Kansas arrived in 1881. A second small group that had first settled in Nebraska arrived in Albina the following year. Migration increased around 1891 and continued up until the First World War. There were about five hundred families living in Portland by 1920 according to Richard Sallet. By that time, they had built their own churches, stores and businesses. Many worked in local businesses that became mainstays of the economy. Of course, they dominated they garbage collection business for decades! These people were a positive factor in the growth of Portland. Of course, there are now thousands of people of Volga German descent living in the Portland area, but they aren't really distinguishable as a unique group. My understanding is the community here in Portland assimilated more quickly than in rural areas where the old culture lasted a bit longer. After the Second World War, the assimilation process was well under way. The younger generations were marrying outside the ethnic group and no longer spoke the old dialect. This caused some tension with the older generation who wanted to keep things the same. I suppose it is a process that most ethnic groups go through as they adapt to life in America. I don't know of anyone in my family who wished that our ancestors had stayed in Russia.

HV: What typical Volga German values were passed along to you?

SS: They were mostly humble people. We were taught to not take ourselves too seriously or be a "show-off." Honesty, integrity and loyalty were highly valued. Cleanliness was another strong trait. Everything had to be kept clean and in good 
working order. They were frugal people - reusing and recycling everything before it became fashionable. They would never buy something they could make or grow. Borrowing money was somewhat frowned upon, except when buying a house or car. If you did have a debt, you always paid it on time or sooner. We were taught to work hard from an early age. Being responsible for ourselves was also important. Being a "burden" to someone else was to be avoided at all costs. People could sometimes have a gruff veneer, but they were always willing to help if you needed it. They valued family and made sure that their children felt secure and protected. Overall, I think they had a sense of balance that is sometimes lacking today. They appreciated what they had and didn't worry about what they didn't have. I think many of these values were ingrained in me and have served me well in life.

HV: Why is your Volga German ancestry of interest to you?

SS: I think it started as an intriguing family mystery. At first, I was focused on genealogy and started to piece together how I was related to so many people. My father was one of four children and my mother was one of thirteen children. It seemed like I was related to everyone when I was growing up. It all started to come into focus as I documented the family connections. Later, I became interested in the history, culture, traditions and music of the Volga Germans. I've done a good deal of reading on the topic and have two websites that I maintain. I served on the AHSGR Oregon Chapter board for about twenty years and also helped found the Center for Volga German Studies at Concordia University. I guess you could say that I'm in fairly deep at this point. It's important to me because I've learned so much about my family and about myself. Many of my childhood mysteries were solved and now make sense to me. I learned not to judge my parents, but to accept that they were also shaped by their parents, grandparents, et cetera. Our history does shape the present and future. I've also learned through DNA analysis how people around the world are connected, not just Volga Germans, but all of us. Even though my ancestry is one hundred percent Volga German, I can now see the evidence of how I am related to people all over the world, many of which have no Volga German ancestry. We all have our own important stories to tell, but we are also bound together in a much larger story of human development and migration.

$\mathrm{HV}$ : Is there anything else you'd like to add?

SS: $\quad$ Yes, I'm very pleased that you chose to study the Volga German community in Portland as the subject of your Master's thesis. When I first started researching my family, I found virtually nothing on this topic at the established history organizations in Portland. Over many years, I've worked on piecing the story of the Volga Germans in Portland together, but it's important to have a qualified historian like you do this work from an independent viewpoint. The story of these 
people deserves to be told. I'm very grateful for all you are doing. Vielen Dank! (Thank you!) 